\title{
EXAMINING THE SOURCES OF SELF-EFFICACY AMONG INSTRUMENTAL MUSIC TEACHERS
}

A Dissertation
presented to
the Faculty of the Graduate School
at the University of Missouri-Columbia
In Partial Fulfillment
of the Requirements for the Degree
Doctor of Philosophy
bey
Br. Brian A. Silvey, Dissertation Advisor
May, 2019


The undersigned, appointed by the dean of the Graduate School, have examined the dissertation titled

\section{EXAMINING THE SOURCES OF SELF-EFFICACY AMONG INSTRUMENTAL}

MUSIC TEACHERS

presented by Bradley J. Regier,

a candidate for the degree of doctor of philosophy,

and hereby certify that, in their opinion, it is worthy of acceptance.

Dr. Brian Silvey

Dr. Wendy Sims

Dr. Brandon Boyd

Dr. Amy Knopps 


\section{ACKNOWLEDGEMENTS}

Thank you to Dr. Brian Silvey for his mentorship and friendship. I will always appreciate your time, insights, and efforts towards my development. Your commitment to teaching and scholarship is inspiring.

Dr. Wendy Sims, thank you for your wisdom and guidance. I will forever cherish our conversations about teaching and life. They have made me a better educator, colleague, and person.

I would also like to thank my committee members, Dr. Brandon Boyd and Dr. Amy Knopps, for their support and encouragement. I am lucky to have you both as mentors.

Thank you to Dr. Christopher Baumgartner and Becky Hughes for checking in on me during this journey.

Finally, I would like to thank my family and friends for their love and support. To Stephanie and Theo: Thank you for your patience and love. This is for us. 


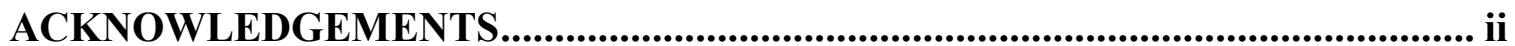

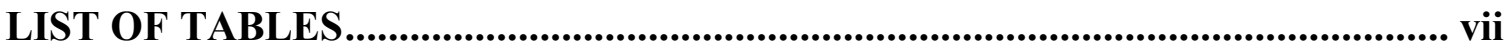

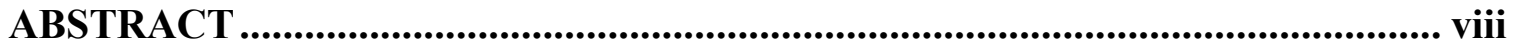

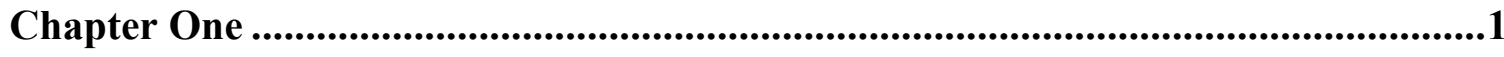

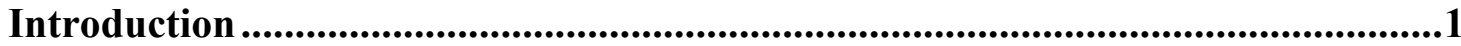

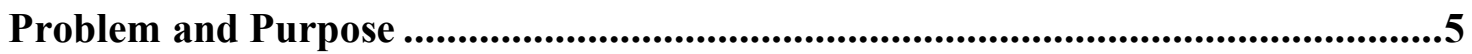

Research Question ...................................................................................................6

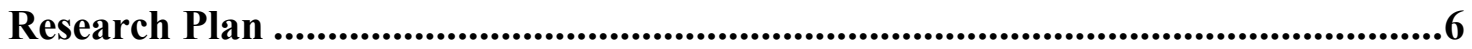

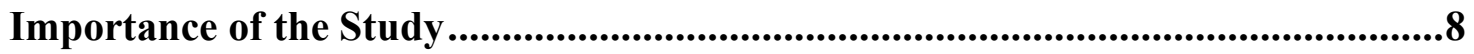

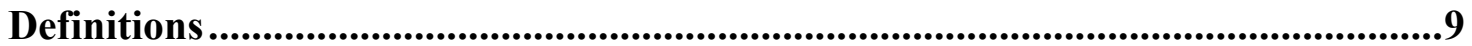

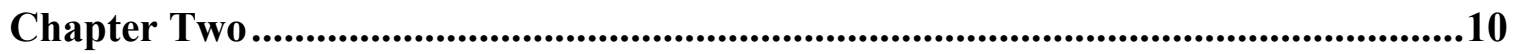

The Sources of Instrumental Music Teachers' Self-Efficacy: A Review of

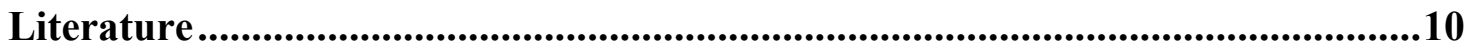

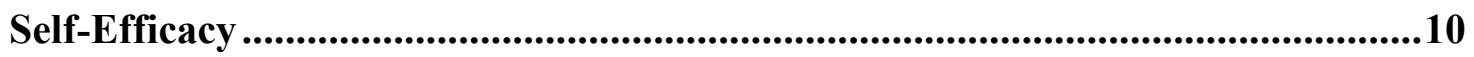

Teacher Self-Efficacy

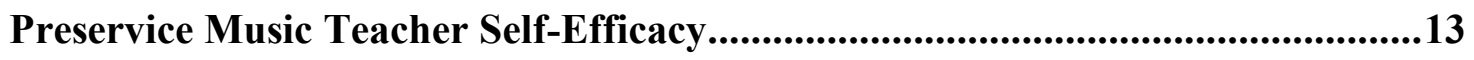

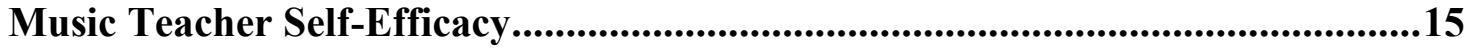

Music Student Self-Efficacy ................................................................................17

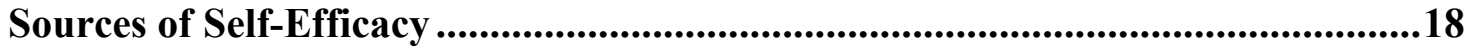

Enactive Mastery Experience..........................................................................19

Vicarious Experience ............................................................................................22

Verbal Persuasion ................................................................................................224 


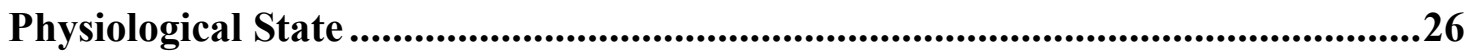

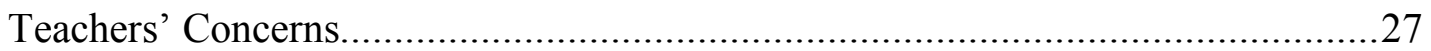

Conclusion.......................................................................................................31

Chapter Three ...........................................................................................................................34

Examining Relationships Among Concert Band Directors' Self-Efficacy for

Teaching Strategies, Its Sources, and Effective Teaching Skills ...........................34

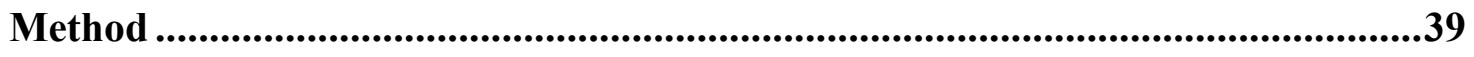

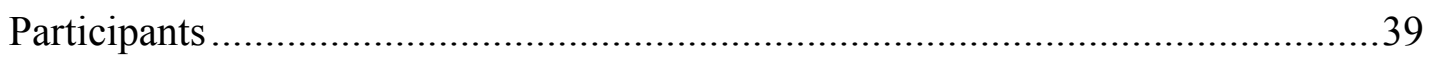

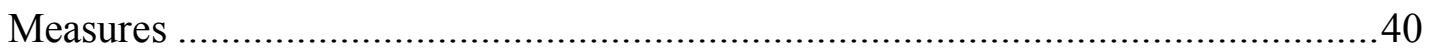

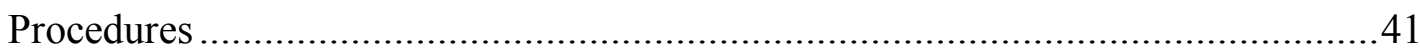

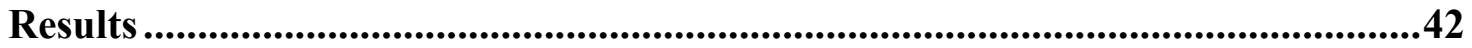

Discussion ......................................................................................................46

Chapter Four ...............................................................................................................55

A Case Study of Preservice Instrumental Teachers' Self-Efficacy and Concerns 55

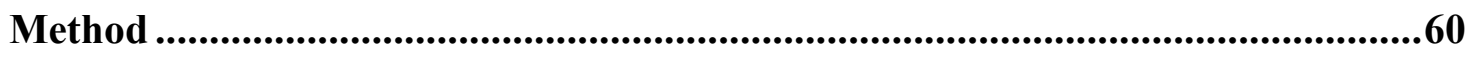

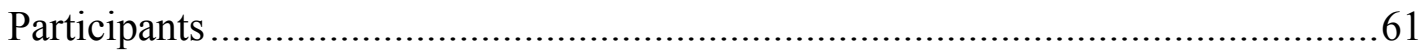

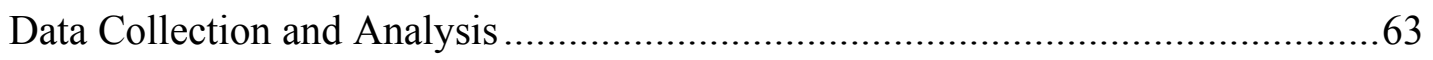

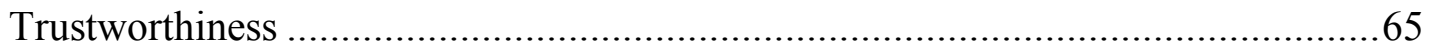

Findings \& Discussion .................................................................................66

Theme One: Value of Professional Teaching Experiences................................67

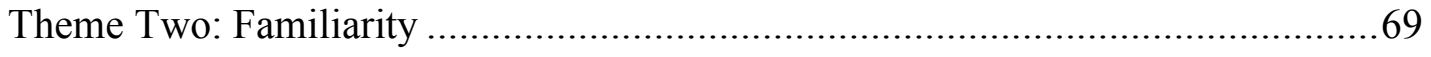

Theme Three: Changing and Clustered Concerns ........................................... 73

Conclusion....................................................................................................... 78 


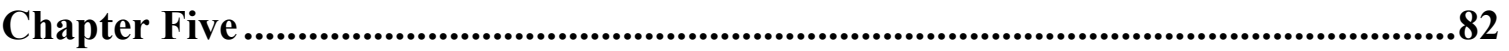

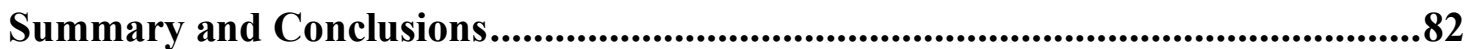

Research Questions and Method...................................................................................83

Major Findings .................................................................................................................83

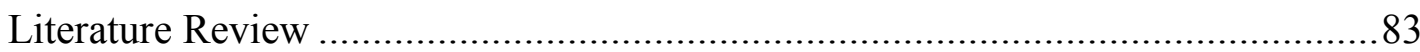

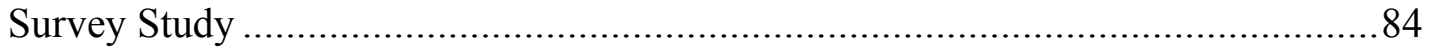

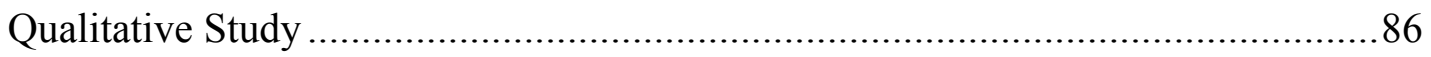

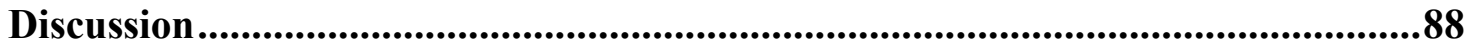

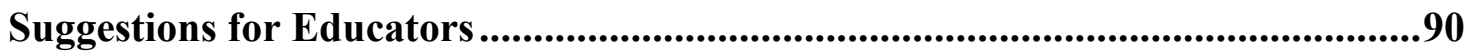

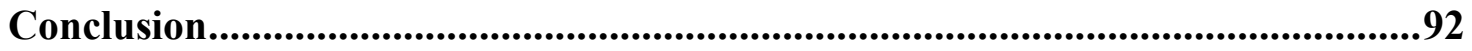

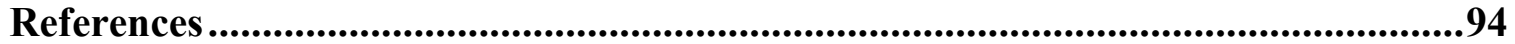

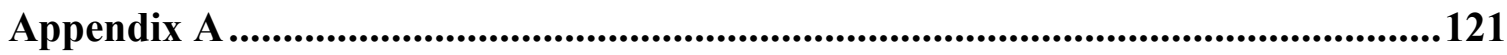

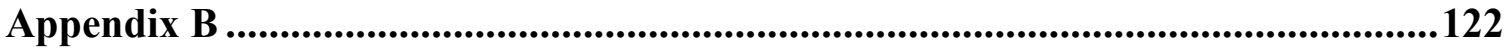

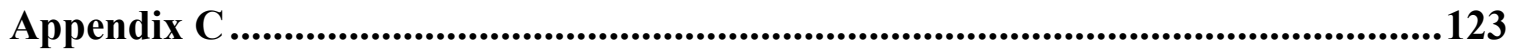

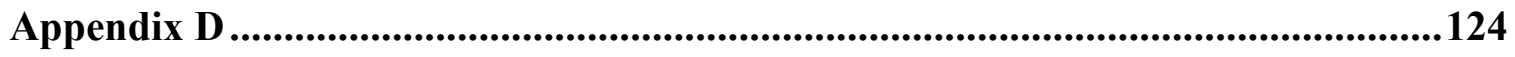

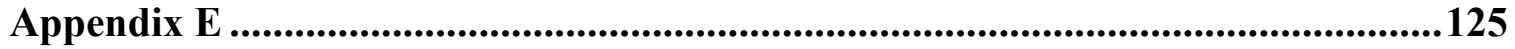

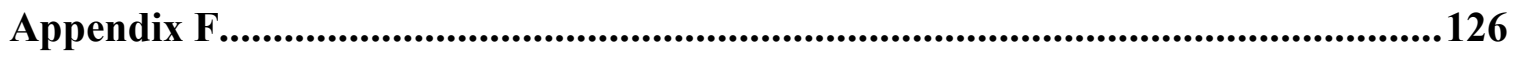

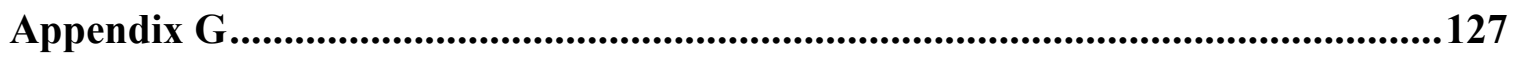

Appendix H....................................................................................................................129

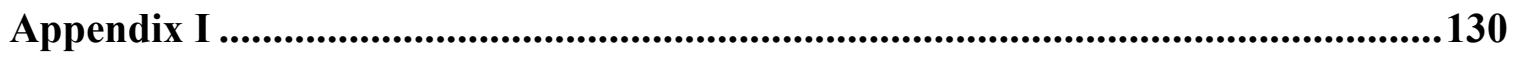


Appendix J....................................................................................................... 133

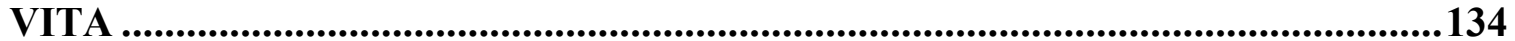




\section{LIST OF TABLES}

Table 1 Means and Standard Deviations of Self-Efficacy Variables ............................42

Table 2 Spearman's Rho Correlations Among Self-Efficacy Variables ..........................43

Table 3 Multiple Regression Models Predicting Concert Band Directors' Self-Efficacy

for Teaching Strategies by Career Stage ..................................................... 44

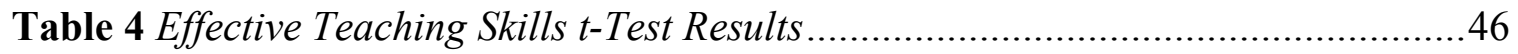

Table 5 Frequency and Sum of Efficacious Experiences Across Time...........................72

Table 6 Sums, Means, and Percentages of Concerns Codes by Metacategory

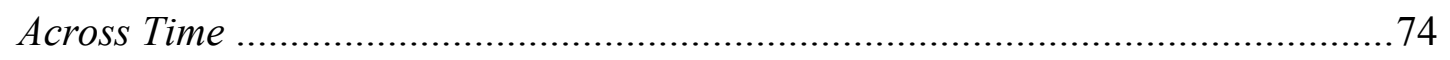

Table 7 Frequency and Sum of Concerns Categories Across Time ..............................74 


\title{
EXAMINING THE SOURCES OF SELF-EFFICACY AMONG INSTRUMENTAL
}

MUSIC TEACHERS

Bradley J. Regier

Dr. Brian Silvey, Dissertation Supervisor

\begin{abstract}
This dissertation comprises three projects that were designed to investigate the extent that mastery experiences, verbal persuasions, vicarious experiences, and physiological state contribute to instrumental music teachers' self-efficacy. The first investigation was a review of the literature about self-efficacy and its sources among general education teachers, music teachers, and preservice teachers. The second investigation was a survey study of how instrumental teachers' self-efficacy for teaching strategies is influenced by its four sources. Results indicated concert band directors' self-efficacy related the most with mastery experiences, followed by verbal persuasions, physiological state, and vicarious experiences, respectively. Further investigation indicated levels of self-efficacy related with years of experience and self-perceptions of effective teaching. The third investigation was a case study of preservice instrumental teachers' self-efficacy and concerns. Participants' beliefs were most impacted by their familiarity with a setting and perceived success of previous pedagogical experiences. Results from these three projects indicated that instrumental music teachers' self-efficacy (a) is most influenced by the relative success of previous teaching experiences, (b) relates to effective teaching behaviors, and (c) improves with experience and familiarity in a setting.
\end{abstract}




\section{Chapter One}

\section{Introduction}

Teachers hold beliefs about their abilities to perform given tasks. Bandura (1997) asserted that these beliefs, which he labeled self-efficacy, control the relationship between cognition and behavior as part of a larger construct known as social cognitive theory. Self-efficacy is a measure of perceived capability, instead of a perception of one's self like self-concept, or a measure of self-worth like self-esteem (Bandura, 2006). Rather than being a global trait, self-efficacy changes depending on the contextual nature of the task. For example, self-efficacy for teaching music may be different than self-efficacy for performing music. Self-efficacy for a task affects individuals' motivations, emotions, choices, and success (Bandura \& Schunk, 1981).

The interpretation of previous experiences and emotional responses associated with a task influences efficacious beliefs (Pajares, 2003). The sources of self-efficacy include the relative success of previous task attempts (mastery experiences), verbal persuasions, observations of others with similar abilities to one's own (vicarious experiences), and physiological state (Bandura, 1997). Because efficacy beliefs are context-specific, the relative influence each source has on self-efficacy can vary. Beginning teachers' self-efficacy to control student behavior may be influenced differently than veteran teachers' as a result of having fewer mastery experiences (Woolfolk Hoy \& Burke-Spero, 2005). Still, mastery experiences are the most influential source of individuals' beliefs (Bandura, 2006, Usher \& Pajares, 2008). Successfully accomplishing a task can improve efficacious beliefs just as unsuccessful attempts can 
weaken them. Therefore, finding ways for teachers to have early and sustained success may impact their self-efficacy to positively influence students' abilities.

Teacher self-efficacy is defined as a teacher's belief in one's ability to bring about change in student learning and behavior (Bandura, 1997; Tschannen-Moran \& Woolfolk Hoy, 2001). The development of teachers' self-efficacy may be cyclical between teacher beliefs, teacher and student behavior, and student academic outcomes (Tschannen-Moran, Woolfolk Hoy, \& Hoy, 1998). Students' performance in the classroom can create new mastery experiences for teachers, which then influence teachers' professional motivations and decisions (Woolfolk Hoy \& Davis, 2006). Over time, successful teaching episodes can affect students' performance in the classroom (Ashton \& Webb, 1986; Moore \& Esselman, 1992; Muijs \& Reynolds, 2002; Ross, 1992) and beliefs towards learning (Anderson, Green, \& Loewen, 1988; Midgley, Feldlaufer, \& Eccles, 1989; Ross, Hogaboam-Gray, \& Hannay, 2001). Based on these results, it seems important to investigate the kinds of experiences that might improve music educators' self-efficacy and potential teaching and learning outcomes in the music classroom.

Efficacy beliefs can influence teachers' behaviors and dispositions. Teachers with a higher sense of efficacy were found to use more effective teaching strategies in the classroom, such as small group work (Ashton \& Webb, 1986; Chacon, 2005) and activity-based instruction (Czerniak \& Schriver-Waldon, 1991; Riggs \& Enochs, 1990) than did colleagues with lower efficacy. Higher self-efficacy beliefs among teachers also related to greater commitment toward teaching (Coladarci, 1992), lesson planning and organizing (Allinder, 1994; Muijs \& Reynolds, 2002), and job retention (Burley, Hall, Villeme, \& Brockmeier, 1991). Teachers with high self-efficacy reported greater job 
satisfaction (Klassen \& Chiu, 2010) and were less critical of student errors (Ashton \& Webb, 1986) than those with lower self-efficacy. These findings could highlight similar relationships among music teachers' self-efficacy and pedagogical approaches and beliefs.

Although investigators have examined the self-efficacy of music students (Davison, 2010; Fisher, 2014; McPherson \& McCormick, 2006; Ritchie \& Williamon, 2011; Watson, 2010; Wehr-Flowers, 2006; Zelenak, 2015), few have studied music teachers' self-efficacy. The efficacious beliefs of music teachers have been examined in studies of identity (Wagoner, 2011), band ensemble pedagogy (Regier, 2018), professional development workshop effectiveness (Quesada, 1992), and participation in mentorship programs (Koerner, 2017). The support that music teachers are provided may influence their self-efficacy. Hancock (2008) found that high levels of school and classroom efficacy lowered the chance of teacher migration and attrition. Similarly, Wagoner (2011) reported K-12 music teachers' efficacious beliefs moderately correlated with their teaching commitment. How pedagogical experiences impact music teachers' levels of self-efficacy and its sources remains unknown.

The relative influence that years of experience has on teachers' self-efficacy is unclear. Researchers found that music teachers reported higher self-efficacy as a result of experience (Biasutti \& Concina, 2018; Wagoner, 2011), but others have found no such relationship in studies of high school band directors (Regier, 2018) and first-year teachers (Koerner, 2017). Similar conflicting results have been reported among studies of general education teachers. Woolfolk Hoy and Burke-Spero (2005) reported that teacher efficacy beliefs may decrease during the first year of service because the position is likely more 
difficult when student teacher support systems are no longer present. However, efficacy beliefs likely improve once teachers have successful mastery experiences. Klassen and Chiu (2010) found that over the course of a career, teachers' efficacy increased until approximately the 23 rd-year when there was a steady decline associated with motivation. Perhaps investigating the influence of each source of self-efficacy on early, mid-, and late career music teachers' beliefs can provide contextual understanding about their development.

Music teachers' efficacy beliefs begin to develop at the preservice level. Curricular opportunities designed to develop the pedagogical abilities of preservice teachers such as peer teaching and field observations (Prichard, 2017) and early fieldteaching experiences (Paul et al., 2001) impacted participants' self-efficacy. Preservice teachers' efficacy for classroom management (Austin \& Miksza, 2012; Bergee, 2002) and teaching strategy (Austin \& Miksza, 2012) have been improved with training and peer teaching opportunities. However, the relative strength of efficacious beliefs may be inflated at the preservice level because of unrealistically high expectations during early teaching episodes, resulting in beliefs that decrease over time (Barnes, 1998; Woolfolk Hoy \& Burke-Spero, 2005). Low efficacious beliefs can increase the influence of physiological state on teachers' self-efficacy to affect change in students, resulting in increased anxiety and stress (Ghaith \& Shaaban, 1999; Pyper, 2014).

Teachers' anxiety and uncertainties have been defined as "teacher concerns" (Fuller, 1969). Fuller's initial investigation of teachers' concerns during a student teaching seminar was later developed into a model by Fuller and Bown (1975) designed to study the growth of teachers. The authors suggested that teachers identify three linear 
stages of concerns: (1) self-survival, (2) task, and (3) student-impact. Preservice and beginning teachers would identify more self and task concerns than veteran teachers. Experienced teachers would focus on student learning concerns more than lessexperienced teachers. With proper support, teachers could more quickly identify the needs of their students and spend less time on task and self-survival concerns.

Fuller and Bown's model has been used as a lens to investigate the development of preservice music teachers (Berg \& Miksza, 2010; Broyles, 1997; Campbell \& Thompson, 2007; Killian, Dye, \& Wayman, 2013; Miksza \& Berg, 2013; Powell, 2014, 2016). Participants have identified concerns in linear stages (Broyles, 1997; Killian, Dye, \& Wayman, 2013; Miksza \& Austin, 2010; Yourn, 2000) and in clusters of categories such as instrument-specific pedagogy or rehearsal strategies (Berg \& Miksza, 2010; Powell, 2014, 2016). These varying results related to teachers' concerns identification may be a product of contextual factors in the pedagogical setting, such as the type of ensemble or age group being taught (Miksza, \& Berg, 2013). A qualitative investigation concerning the transition from preservice teaching to student teaching may provide information about the experiences that influence preservice teachers' concerns, concerns development, and self-efficacy for teaching.

\section{Problem and Purpose}

Teachers' self-efficacy can impact their dispositions, behaviors, and students' motivation, self-efficacy, self-regulation, and achievement (Woolfolk Hoy \& Davis, 2006). Although teacher efficacy beliefs have been examined in contexts such as general education (Ashton \& Webb, 1986; Tschannen-Moran et al., 1998; Woolfolk Hoy \& Burke-Spero, 2005) and music (Biasutti \& Concina, 2018; Koerner, 2017; Regier, 2018; 
Wagoner, 2011), few have explored how the sources of self-efficacy might influence music teachers' beliefs. Considering that self-efficacy is often contextual to the specified task or academic domain, it seems appropriate to investigate instrumental teachers' selfefficacy and its sources. Therefore, the purpose of this study was to examine the sources of preservice and in-service instrumental music teachers' self-efficacy.

\section{Research Question}

The following primary research question guided my investigation: To what extent mastery experiences, verbal persuasions, vicarious experiences, and physiological state contribute to instrumental music teachers' self-efficacy? I was also interested in how efficacious beliefs might relate to effective teaching skills.

\section{Research Plan}

To answer my overarching research question, I reviewed the extant literature about teacher self-efficacy, the sources of self-efficacy, and teachers' concerns. By synthesizing the previous research, I identified ways for instrumental teachers to improve their self-efficacy and how these behaviors might transfer to their students' development. Then, in two separate studies, I explored how instrumental teachers' self-efficacy may be influenced and possible relationships with teaching skills. Thus, this study comprised three investigations designed to examine how instrumental teachers' self-efficacy is influenced and the potential relationships with pedagogical approaches.

The first investigation was a review of the literature about self-efficacy and its sources among general education teachers, music teachers, and preservice teachers. Because there are many research findings indicating that self-efficacy can impact teachers' behaviors and students' outcomes in other academic fields, investigating how 
these findings may transfer to the efficacious development of instrumental music teachers seemed warranted. Particular attention was given to providing ideas for improving teacher self-efficacy through the four sources (i.e., mastery experience, vicarious experience, verbal persuasion, and physiological state). This review of literature was designed to identify pedagogical behaviors that can improve students' music achievement and teachers' self-efficacy.

The second investigation was a study of how instrumental teachers' self-efficacy is influenced by its sources. I also explored how their beliefs related to their selfperceptions of effective teaching. Researchers have investigated the self-efficacy of music teachers as it relates to identity (Wagoner, 2011), commitment (Hancock, 2008), mentorship program participation (Koerner, 2017), and band ensemble pedagogy (Regier, 2018), but few identified how the sources might impact efficacy and their potential pedagogical outcomes. Specific items investigated included how efficacy and its sources changed over time, relationships between effective teaching behaviors and teacher selfefficacy for teaching strategies, and whether efficacy for teaching strategies differed by experience level. The findings from previous research were unclear concerning the impact that years of teaching had on teacher efficacy (Biasutti \& Concina, 2018; Regier, 2018; Wagoner, 2011), so further investigation seemed warranted. This study may provide instrumental music teachers with ways to advance their pedagogical abilities. Music teacher educators might use results related to effective teaching behaviors to inform the design of course content.

The third investigation was an exploration of the experiences and concerns that influence preservice instrumental teachers' self-efficacy. Although researchers have 
examined how mediated experiences can influence self-efficacy for teaching behaviors (Austin \& Miksza, 2012; Bergee, 2002; Prichard, 2017), as well as undergraduates' concerns for teaching (Berg \& Miksza, 2010; McLaughlin, 1991; Miksza \& Berg, 2013; Powell, 2014, 2016), I wanted to investigate qualitatively how preservice teachers' experiences influenced their teaching confidence. Furthermore, relationships may exist between participant concerns and their perceived efficacy for teaching. I was interested in preservice teachers' concerns and efficacious experiences from pre-student teaching to student teaching placements, as these weeks may reveal unique concerns when changing teaching settings. Understanding how curricular and student teaching experiences influence preservice teachers' self-efficacy could inform music teacher educators' curricular choices for pre-student teaching and student teaching field experiences. In the concluding chapter of my dissertation, I synthesized the findings of my studies, discussed the implications of the results, and provided ideas for future research. Results will be connected in ways that contribute to our understanding of instrumental teachers' self-efficacy and its impact on teacher development and student learning.

\section{Importance of the Study}

These investigations will provide insight into how instrumental teachers' selfefficacy is influenced and how it may impact teachers' approaches in the classroom. Examining differences between early, mid-, and late career teachers builds on our understanding of teacher development and the potential needs of teachers at various stages of their career. Further investigation into how efficacious beliefs relate to effective teaching behaviors and concerns can impact those tasked with developing undergraduate curriculum and professional development programs. Identifying influences and outcomes 
of teachers' self-efficacy can provide evidence to develop teachers' beliefs as a way to improve students' behavioral, performance, and academic outcomes (Woolfolk Hoy \& Davis, 2006).

\section{Definitions}

- High School Band Director: A band director teaching students in grades 9-12.

- Preservice Teacher: An undergraduate student enrolled in a teacher education program at a college or university.

- Mastery Experience: Memories of an individual's past successes or failures in an activity.

- Physiological State: Individuals' feelings, emotions, and physical response towards an identified task.

- Vicarious Experience: The observation of others with similar characteristics to an individual performing an identified task.

- Verbal Persuasion: Feedback from respected individuals regarding an identified task. 


\section{Chapter Two}

\section{The Sources of Instrumental Music Teachers' Self-Efficacy: A Review of Literature}

Self-efficacy has the potential to impact teachers' dispositions and behaviors, and students' achievement and motivation (Woolfolk Hoy \& Davis, 2006). The efficacious beliefs of music teachers likely begin to develop during their undergraduate study (Prichard, 2017; Regier, 2018) and have been explored in relation to commitment (Hancock, 2008), mentorship program participation (Koerner, 2017), band ensemble pedagogy (Regier, 2018), professional identity (Wagoner, 2011), and professional development (Quesada, 1992). Although the findings of these studies indicated how selfefficacy may be influenced, the pedagogical approaches related to music teacher beliefs remain relatively unknown, particularly among instrumental teachers. Therefore, I will describe ways instrumental music teachers' efficacious beliefs can be influenced and how beliefs may impact their pedagogical strategies and students' behaviors and achievement.

\section{Self-Efficacy}

Individuals have beliefs about their ability to accomplish a task. Bandura (1997) theorized that human agency, or the purposeful pursuit of a chosen action, is influenced by our behavior, cognition, and environment. The relationship between behavior and cognition is believed to be controlled by one's self-efficacy, or the belief in one's ability to produce a given outcome. This psychological construct allows individuals, when presented with a task, to cognitively evaluate their potential for success based upon previous experiences and physiological state (Usher \& Pajares, 2008). Efficacy beliefs are theorized to affect our choices, motivations, emotions, and eventual successes or failures. 
Self-efficacy is different from other constructs like self-concept, self-esteem, locus of control, and outcome expectancies. Self-concept has been defined as a composite perception of one's self, whereas self-esteem is a measure of self-worth (Bandura, 2006). Locus of control involves whether individual actions or external forces influence outcomes. Outcome expectations are the positive and negative physical, social, and self-evaluative judgements one makes about the outcomes of their performance. Selfefficacy differs from these other constructs in that it is a measure of perceived capability, influencing individual levels of optimism, effort, and persistence.

Self-efficacy is not a global trait, but rather is context-specific (Bandura, 1997). Early investigations of self-efficacy measured the effectiveness of psychotherapy on individuals' beliefs to confront phobias (Bandura, 1983). These interventions successfully raised patients' efficacy and decreased their phobia. Since these initial studies, the scope of efficacy research has broadened greatly to include the fields of business, industry, health, athletics, and education (Maddux, 1995).

\section{Teacher Self-Efficacy}

Teacher self-efficacy is defined as a teacher's belief in one's ability to bring about change in student learning and behavior (Bandura, 1997; Tschannen-Moran \& Woolfolk Hoy, 2001). The reciprocal relationships associated with teacher efficacy makes it a powerful construct in education (Tschannen-Moran, Woolfolk Hoy, \& Hoy, 1998). Students' classroom experiences such as successfully or unsuccessfully accomplishing academic tasks creates new mastery experiences for teachers, which then influence their future motivations and decisions (Woolfolk Hoy \& Davis, 2006). Successful mastery experiences can lead to greater effort and motivation to teach, which leads to better 
performance by the teacher and students, resulting in greater teacher efficacy. Unsuccessful experiences can have alternate effects on teacher and student outcomes. Woolfolk Hoy and Davis (2006) proposed a framework indicating that teacher selfefficacy affects both student and teacher outcomes directly, indirectly, and relationally. Teacher efficacy can affect students' motivation (Midgley, Feldlaufer, \& Eccles, 1989), self-efficacy (Anderson, Green, \& Loewen, 1988; Ross, Hogaboam-Gray, \& Hannay, 2001), self-regulation (Woolfolk Hoy \& Davis, 2006), and academic achievement (Ashton \& Webb, 1986; Moore \& Esselman, 1992; Muijs \& Reynolds, 2002; Ross, 1992).

Relationships exist between teachers' self-efficacy and their pedagogical approaches. Researchers have found that highly efficacious teachers implemented activity-based teaching strategies (Czerniak \& Schriver-Waldon, 1991; Riggs \& Enochs, 1990), used cooperative learning techniques (Dutton, 1990), and were more willing to try new teaching methods to meet individual student needs (Allinder, 1994; Berman, McLaughlin, Bass, Pauly, \& Zellman, 1977; Cousins \& Walker, 2000) than teachers with lower efficacy. Teachers with high efficacy were less critical of students who made errors (Ashton \& Webb, 1986; Gibson \& Dembo, 1984), worked longer with students who were struggling, placed students in small groups to work, and were less likely to present a lesson in a lecture format (Ashton \& Webb, 1986; Chacon, 2005). These findings indicate that teacher efficacy can have important implications on pedagogical methods and strategies used in the classroom.

Teacher self-efficacy may also affect one's own teaching behaviors and dispositions. In a meta-analysis of teacher efficacy studies, Klassen and Tze (2014) found 
that teacher efficacy and personality each had a small but significant effect on teacher effectiveness. Highly efficacious teachers also sought out better teaching methods, experimented with instructional materials, taught the whole class for longer periods of time, and displayed a greater ability to plan and organize than those with lower efficacy (Allinder, 1994; Muijs \& Reynolds, 2001). Efficacious teachers have reported higher levels of commitment towards teaching (Coladarci, 1992) and are also more likely to remain in the teaching profession (Burley, Hall, Villeme, \& Brockmeier, 1991; Glickman \& Tamashiro, 1982). Klassen and Chiu (2010) found positive relationships between job satisfaction and efficacy for classroom management and teaching strategies. The numerous teaching dispositions influenced by self-efficacy may indicate the need to develop preservice and professional teachers' beliefs.

\section{Preservice Music Teacher Self-Efficacy}

Teachers begin to develop their self-efficacy during undergraduate teacher preparation programs (Baughman \& Baumgartner, 2018; Prichard, 2017). Preservice teachers' beliefs develop at an early stage of their undergraduate program (Martin, 1989) when efficacy beliefs are most impressionable (Bandura, 1986). Self-efficacy for teaching likely improves over time (Hoy \& Woolfolk, 1990; Woolfolk Hoy \& BurkeSpero, 2005) and may be more influenced by coursework in settings where individuals have few pedagogical experiences such as jazz band (Regier, 2018). Preservice experiences appear to have a lasting impact on teachers' confidence to influence student achievement and behaviors.

The kinds of pedagogical experiences offered to preservice music teachers might influence the relative strength and development of teaching efficacy. Prichard (2017) 
used a mixed-methods study design to investigate preservice music teachers' efficacy for, and commitment to, teaching. Participants' efficacious beliefs correlated with their commitment and were influenced by peer teaching episodes, field experiences in $\mathrm{K}-12$ classrooms, and the mentoring they had received in an introductory music education course. The author of the study reported that peer-observations during teaching episodes were also beneficial in raising participants' teaching confidence. Blackwell and Roseth (2018) examined preservice teacher efficacy for secondary woodwind instrument teaching. Results indicated that efficacy and motivation for woodwind teaching strategy could be raised as a result of problem-based learning. However, initial teachers' efficacy beliefs can often be inflated because of misjudging the difficulty of teaching tasks (Woolfolk Hoy \& Burke-Spero, 2005). Barnes (1998) found that undergraduate string students who taught lessons to community children for two-semesters had higher efficacy beliefs at the beginning of the program than at the end but displayed improved teacher effectiveness as a result of the program. These results may speak to the fluidity of selfefficacy beliefs as they relate to individuals' expectations of a task and how they interpret their teaching experiences.

Researchers have also examined preservice music teachers' self-efficacy for specific teacher behaviors. For example, Bergee (2002) investigated the classroom management self-efficacy of preservice vocal and instrumental teachers. Direct and mediated experience groups received classroom management training, followed by the direct experience group applying their skills in a field experience setting. Both groups showed substantial gains in their classroom management self-efficacy beliefs, although the direct group seemed to retain a heightened sense of efficacy for a longer period of 
time than the mediated group. Austin and Miksza (2012) measured the effects of a precollegiate music teacher recruitment program on high school band students' efficacy for teaching strategy and classroom management. They found a significant correlation between teaching strategy efficacy and teacher identity, as well as significant gains for classroom management efficacy as a result of program participation. The results of these studies suggest preservice music teacher self-efficacy for pedagogical strategies can be influenced positively through teacher educator mediations and preparation.

\section{Music Teacher Self-Efficacy}

Similar to other academic fields, music teacher self-efficacy relates to numerous professional constructs and behaviors. Wagoner (2011) examined K-12 music teachers' identity through measures of efficacy and commitment. Results indicated efficacy and commitment to be moderately correlated. Furthermore, teachers' efficacy increased slightly with experience. Similarly, music teachers with reported high levels of school and classroom efficacy have been found to be less at risk for attrition and migration, likely due to the administrative and parental support they receive (Hancock, 2008). Perhaps administrators' and parents' positive verbal feedback function to efficaciously and emotionally support teachers as they improve their pedagogical skills.

Mentorship programs provide professional support for music teachers, particularly novices. Koerner (2017) investigated the influence of mentoring programs on beginning music teachers' efficacy, commitment, and reflective practice. Teacher outcomes were not influenced by the perceived effectiveness of the mentor, nor were they significantly different after four months of data collection. Participants may have lacked comprehensive mentorship programs or held high initial levels of efficacy that negated 
any potential progress for teaching beliefs. Woolfolk Hoy and Burke-Spero (2005) found that teaching self-efficacy could decrease from the end of student teaching to the end of the first teaching year among non-music teachers. This finding was suggested to be a result of cooperating teacher support systems no longer being present and self-perceived poor classroom management abilities. Beginning teacher support systems that address teaching strategies, pedagogical growth, and psychological support over multiple years may play an important role in positively influencing music teacher efficacy development (Koerner, 2017).

There is scant evidence about the impact that educator workshops have on music teacher efficacy and development. Quesada (1992) studied 27 music teachers' selfefficacy for, and willingness to teach, Puerto Rican music. Using a pre-test/post-test study design, an experimental group received teaching materials and participated in a nine-hour pedagogical session whereas a control group only received the teaching materials. Each group was then asked to use the materials in their scheduled class times. Post-test results indicated that the experimental group was significantly more efficacious for teaching Puerto Rican music than the control group, although the control group also significantly increased their level of efficacy. Results also indicated participants’ willingness to teach Puerto Rican music did not significantly increase as a result of workshop participation. Professional development opportunities likely effect teachers' beliefs about their ability to teach a given subject matter but may not necessarily increase their willingness to implement what they learned, possibly due to curricular, budgetary, or staffing constraints. Contingent feedback that supports mastery experiences after workshops may be particularly important for raising teachers' efficacy and 
implementation of a new teaching strategy (Tschannen-Moran \& McMaster, 2009). Further investigation into the influence of music workshop participation on teacher behaviors and beliefs could inform our understanding of how self-efficacy is influenced by developmental experiences.

\section{Music Student Self-Efficacy}

Music teachers may improve their self-efficacy and student musical outcomes by developing student self-efficacy. Students who are engaged in musical activities such as learning an instrument or singing have reported higher efficacious beliefs for musical learning than their counterparts (Ritchie \& Williamon, 2011). The self-efficacy of music students has been studied in many contexts, including singing experience (Fisher, 2014), modeled instruction for jazz improvisation (Davison, 2010; Watson, 2010), collaborative learning strategies (Pike, 2014), music teacher interpersonal behavior (Royston, 2013), and individual practice strategies (Nielsen, 2004). Considering that students who believe themselves to be inadequate musicians were more likely to discontinue instrumental study and begin other activities or sports (Hallam, 1998), improving students' selfefficacy in the music classroom is important for retention.

Students' efficacy beliefs have also been examined within the context of music performance ability. Findings have indicated students' self-efficacy to be the most important predictor of performance achievement, even after accounting for grade level and amount of practice (McCormick \& McPherson, 2003; McPherson \& McCormick, 2006). Similarly, instrumental students' beliefs were found to moderately predict music aptitude (Zelenak, 2015) and jazz improvisation ability (Ciorba, 2009), although improvisation beliefs may be influenced by gender as a result of social-psychological 
factors (Wehr-Flowers, 2006). Given that self-efficacy could be an important predictor of student musical achievement, teachers may need to give more attention to students' selfperceptions of performance (McPherson \& McCormick, 2006). To this end, teachers can challenge students with proximal music performance goals and actively encourage them during the learning process (Pajares, 2003).

\section{Sources of Self-Efficacy}

Although relationships between music teacher self-efficacy and various psychological constructs have been examined, few studies include how beliefs are influenced or change. Self-efficacy beliefs are interpreted from four sources of information: enactive mastery experiences (results of previous tasks), vicarious experiences (observation of peers with similar abilities to one's own), verbal/social persuasions (feedback from others), and physiological state (emotional and physical conditions) (Bandura, 1997). Educational researchers have examined the sources of mathematical efficacy of college students (Lent, Lopez, \& Bieschke, 1991) and middle school students (Klassen, 2004), middle school science students (Britner \& Pajares, 2006), student computer use (Smith, 2001), and college student career development (Anderson \& Betz, 2001). Mastery experiences have the most effect on beliefs across academic domains, but the relative influence of each source can depend on contextual factors such as gender, ethnicity, academic ability, and academic subject (Usher \& Pajares, 2008). For example, boys and girls have reported similar efficacy beliefs for mathematics at the elementary level (Eccles, 1983), but boys report higher efficacy beliefs by middle school (Pajares, 2005). By understanding how these sources influence 
the efficacy of different student populations at different times, teachers may better design strategies that lead to higher student confidence and performance.

Similar to other academic fields, music performance efficacy seems to be strongly influenced by mastery experiences, followed by verbal/social persuasions, physiological state, and vicarious experiences, respectively (Hendricks, 2014; Lent et al., 1991; Lopez \& Lent, 1992; Matsui, Matsui, \& Ohnishi, 1990; Usher \& Pajares, 2006; Zelenak, 2015). In a study of high school instrumentalists in a competitive honor orchestra setting, Hendricks (2014) found that student efficacy beliefs were most influenced by mastery experiences, although females may have responded differently than males to vicarious and verbal experiences, further illustrating the contextual nature of efficacy beliefs. Zelenak (2015) recommended that teachers provide performance opportunities that build student efficacy, such as performing in front of receptive audiences with appropriately challenging repertoire. Other ideas included using peer models to build vicarious experiences and teaching students how to control their anxiety during performances to improve their physiological state.

\section{Enactive Mastery Experience}

Enactive mastery experiences are often the most influential source for selfefficacy because they provide authentic evidence by which to gauge potential success (Bandura, 1997; Usher \& Pajares, 2006). Successful teaching experiences generally raise efficacy beliefs, but repeated failures can lower them, particularly if the failure happens early in the developmental process. However, the chances of early success can be increased by setting appropriately challenging task goals. Even a small performance success can motivate an individual to go beyond their immediate performance level to 
higher goals (Bandura, 1978). Still, persevering and overcoming teaching challenges can develop a resilient sense of efficacy (Bandura, 1997). Teachers that set appropriate learning goals likely increase students' ability to succeed and can also inform their selfefficacy for similar teaching tasks.

Because efficacy beliefs are influenced by previous experiences, it would seem that teacher self-efficacy could increase with pedagogical ability over time. Yet, researchers studying relationships between teachers' self-efficacy and years of teaching experience have found mixed results. The self-efficacy of $\mathrm{K}-12$ music teachers (Wagoner, 2011) and instrumental and vocal teachers (Biasutti \& Concina, 2018) were found to correspond with years of teaching experience. However, high school band directors (Regier, 2018) and beginning music teachers in mentorship programs (Koerner, 2017) did not hold higher self-efficacy beliefs as a result of time spent in the profession. Similar varied results have been found in studies of general education teachers. For example, Tschannon-Moran and Johnson (2011) found that years of teaching did not significantly influence teacher self-efficacy among a sample of elementary and middle school teachers. However, Klassen and Chiu (2010) reported that general education teacher self-efficacy improved from the 1st-year to approximately the 23rd-year, but then declined afterwards. Additional investigation about how self-efficacy and its sources are influenced by years of teaching could provide insight about teachers' efficacious development over time.

Music teachers begin their careers with efficacious beliefs about their teaching ability. These beliefs are often developed from preservice teaching experiences that take place in the schools, often referred to as authentic contextual learning (ACL) activities 
(Paul et al. 2001). The student teaching, peer teaching, and early field experiences are typical ACL activities that were valued by in-service teachers (Bauer \& Berg, 2001; Conway, 2002; Teachout, 1997) and preservice teachers (Haston \& Russell, 2012; Schmidt, 2012). ACL activities have been reported to improve teacher effectiveness (Austin \& Miksza, 2012; Paul et al. 2001) and sense of teacher identity (L'Roy, 1983; Paul, 1998). The relative strength of preservice teacher beliefs often depends on the quality of their experiences (Ross, 1994; Woolfolk Hoy \& Burke-Spero, 2005). Successful authentic teaching experiences likely provide an efficacious foundation from which novice teachers can rely on if teaching becomes difficult.

Identifying and improving behaviors related to music conductor effectiveness may translate to music teacher self-efficacy. Results indicated that conductors who used frequent eye contact increased their students' on-task behavior in the classroom (Yarbrough, 1975; Yarbrough \& Madsen, 1998) and were perceived to be more effective conductors than those with less eye contact (Carvalho, 1997; VanWeelden \& McGee, 2007). Conductors are perceived to be more effective when they talk less in the rehearsal setting (Napoles, 2006, 2007; Witt, 1986; Yarbrough \& Price, 1981), give more negative than positive feedback (Duke \& Simmons, 2006; Whitaker, 2011), provide more specific feedback (Goolsby, 1997; Price \& Yarbrough, 1993; Siebenaler; 1997) and allow for frequent student performance episodes (Duke, Prickett, \& Jellision, 1998) than do less effective conductors. Other behaviors related to perceptions of conductor effectiveness include aural modeling (Goolsby, 1996; Sang, 1987), presentation of material with great affect (Madsen \& Geringer, 1989; Madsen, Standley, Byo, \& Cassidy, 1992) and the use of expressive gesture (Morrison, Price, Geiger, \& Cornacchio, 2009; Price \& Winter, 
1991; Sidoti, 1990; Silvey \& Koerner, 2016). Teachers and conductors that use effective pedagogical behaviors may increase their students' likelihood of improving, resulting in positive student outcomes that inform teacher self-efficacy.

\section{Vicarious Experience}

Teacher self-efficacy is influenced from observing the actions of others. In observational settings, people compare their capabilities in relation to the abilities of the model (Bandura, 1997). Beliefs are more likely to change when individuals are uncertain in their skills or have limited amounts of experience with a task and must rely on social comparisons to evaluate their performance (Usher \& Pajares, 2006). The quality of vicarious experiences often depend on who people choose to compare themselves with (Bandura \& Jourden, 1991). Individuals are more likely to have their self-efficacy positively influenced from viewing a model with similar abilities than one with substantially greater or lesser abilities. For example, the efficacy of an accomplished middle school choral teacher is more likely to be influenced from observing another teacher of similar ability than one with lesser ability. Teachers develop their efficacy from a variety of vicarious experiences such as professional development workshops and graduate coursework.

There is some disagreement on the relative influence of vicarious experiences on teachers' efficacy. Tschannen-Moran and Johnson (2011) reported that undergraduate coursework and professional development, which provide training through observation, have a positive influence on teacher self-efficacy. However, researchers also found the observation of other teachers to have a limited effect on actual instructional change (Guskey, 1989; Stein \& Wang, 1988). Feedback and support from respected individuals 
may be needed to change teacher behavior and strategy in the classroom after professional development or observational experiences (Tschannen-Moran \& McMaster, 2009). Similar support and structure may be necessary for preservice teachers' observational experiences in order to improve their confidence for teaching (Conway, 2012; Prichard, 2017).

Graduate course instructors also use vicarious experiences to develop in-service teachers' pedagogical strategies and behaviors. Efficacious growth in a graduate class setting may depend on the quality of information learned when acquiring the degree, rather than the attainment of one (Tschannen-Moran \& Johnson, 2011). The relative influence of professional development experiences on teacher self-efficacy is nuanced and depends on the quality of experience and support provided. Investigating the qualities and context of support following observational experiences may provide ideas for creating more impactful vicarious experiences for teachers' development.

Approaching an observational experience with a specific mindset may influence possible efficacious outcomes. Individuals who view an observation as an opportunity to develop their own skills and knowledge, rather than self-compare, can strengthen their personal efficacy (Bandura, 1997; Schunk, 1987). For example, instrumental teachers that approach observations with a growth mindset may feel encouraged to transfer observed teaching behaviors to their own rehearsal hall. Making competitive comparisons during an observation of an advanced teacher can lead to lower efficacy beliefs and selfdeprecation (Kitchel, 2017). Moriarty, Douglas, Punch, and Hattie (1995) investigated the extent to which self-efficacy mediates the relationship between environment and achievement among seventh-grade students. Results indicated that a cooperative 
environment led to higher student achievement, efficacy, and more appropriate behavior than a competitive environment. Instrumental teachers who also approach their growth and teaching with a non-competitive mindset may potentially improve their own efficacy for teaching and their students' self-efficacy for music learning.

\section{Verbal Persuasion}

The social persuasions of others play a role in developing teacher efficacy beliefs. Although the enduring influence of verbal persuasions on self-efficacy may be limited, feedback can encourage self-change when it is authentic and specific. Support can be important for those who are not yet skilled at making accurate self-appraisals of ability (Usher \& Pajares, 2006). Instrumental teachers are better able to sustain their sense of efficacy when teaching becomes difficult if peers, administrators, and mentors provide verbal support versus doubts (Bandura, 1997). Increased levels of self-efficacy can be sustained if an individual successfully performs a task after receiving feedback but can also be short-lived if effort does not produce the desired outcome (Schunk \& Zimmerman, 2007). Verbal persuasion alone cannot change teacher self-efficacy, but it can be the motivating factor in persuading a teacher to put forth more effort to improve pedagogical skill and student ability (Bandura, 1997).

The quality and specificity of feedback influences teachers' and students' selfefficacy. Feedback about personal effort or ability for accomplishing a task can increase efficacious beliefs (Schunk, 1982; Schunk \& Cox, 1986). Learners' self-efficacy in the early stages of skill development are influenced by feedback on their ability to accomplish a task (Schunk, 1984). Pajares (2006) suggested that teachers may want to foster students' belief that ability can be changed and effort can overcome obstacles. 
Although the ensemble setting often creates an environment where expert teachers provide more negative than positive feedback (Duke \& Henninger, 2002), teachers can still bring attention to students' progress as a result of their ability or effort after successfully performing an objective. Furthermore, teachers can increase their awareness of students' attributional beliefs that failure is a result of ability level, and encourage students to consider how effort and practice strategies influence achievement (Austin \& Vispoel, 1998).

The persuasion of mentors likely influences the efficacy and behavior of instrumental teachers, particularly novices. New music teachers have reported feeling isolated and emotionally unsupported in their new positions (Benson, 2008). Koerner (2017) recommended that mentors promote reflection and inquiry in addition to providing psychological and pedagogical support for mentees. Researchers have suggested that mentors address specific music teacher needs, such as managing student behavior, administrative tasks, and class scheduling conflicts (Conway, 2003; DeLorenzo, 1992). Mentors can also guide mentees attention towards professional growth at professional development workshops, music contests, and during co-teaching experiences. Instrumental teachers that work in a supportive environment and are mentored to persist through difficulties are more likely to develop resilient self-efficacy for teaching, particularly in their beginning years (Bandura, 1997). By using the strategies proposed by their mentors, instrumental teachers can improve their own psyche, professional disposition, and teaching strategies. 


\section{Physiological State}

The fourth source of self-efficacy is one's physiological state towards a given task (e.g., stress, arousal, or fatigue). Individuals assess their physiological state to make judgements about their potential to successfully complete a task (Usher \& Pajares, 2006). Heightened arousal, such as performance anxiety, can negatively impact self-efficacy when individuals acknowledge their tension and become even more anxious. Positive emotions during a task, such as the joy felt during and after conducting a successful concert, can increase instrumental teachers' self-efficacy. Arousal can also depend on the achievement level of the individual. High achievers may be energized by arousal, but low achievers may find the feeling debilitating (Hollandsworth, Glazeski, Kirkland, Jones, \& van Norman, 1979). Physiological state is also affected when tasks require physical strength or stamina. When people experience physical pain that keeps them from attaining an objective, their efficacy is lessened. Considering the range of motion typically needed to conduct an ensemble, physical indicators of anxiety or stress could influence instrumental teachers' self-efficacy for expressive gesture.

Instrumental teachers can help students understand and control their own physiological state. Hackett and Betz (1989) suggested that teachers should foster both student competence and confidence because efficacy beliefs may better predict motivation and future academic choices than actual attainments. Teachers can also raise student efficacy and achievement by developing students' self-regulatory behaviors such as finishing homework on time, persevering when performance becomes difficult, organization of practice time, and motivating oneself to practice when other activities are available (Miksza \& Tan, 2015; Pajares, 2006). Although developing these behaviors can 
reduce stress among some students, failure to see progress after putting forth effort can be frustrating for other students. Teachers can provide verbal support for students struggling with meeting academic goals and musical objectives. Assigning shorter rehearsal segments or slowing down the introduction of new material can help stressed students find musical success.

Although few researchers have examined music teachers' physiological states, anxiety among musicians has been researched extensively (Hamann, 1982; MarchantHaycox \& Wilson, 1992; Wesner, Noyes, \& Davis, 1990; Wilson, 2002). Performers consistently report auditions as the most stressful performance situations because of the scrutiny, evaluation, and hierarchy of achievement that is often created (Wilson \& Roland, 2002). Diaz (2018) found that meditation practices helped alleviate music performance anxiety among a population of collegiate musicians. Results also indicated that higher mindfulness predicted lower performance anxiety, but higher perfectionism predicted higher anxiety. Other effective non-medicated strategies for combating musicians' anxiety have included positive self-talk (Seligman, 1995), mental practice and imagery (Murphy \& Jowdy, 1992; Roland, 1997), and viewing anxiety as a normal, positive emotion (Hanton \& Jones, 1999; Roland, 1994). It would seem that these nonmedicated interventions for stress could transfer to the needs of instrumental teachers. Finding ways to reduce anxiety and stress can lead to performances that better reflect an individual's preparation rather than their nervousness (Diaz, 2018), and positively influence physiological sources of self-efficacy.

Teachers' Concerns. Studying teachers' perceived problems or concerns may reveal opportunities to help alleviate their anxiety. Fuller (1969) studied student-teachers' 
concerns by examining their written statements and discussing their feelings with them to better understand their growth. A developmental model that included three categories of concerns emerged: (a) pre-teaching, non-concern; (b) early teaching, self-concerns; and (c) late teaching, pupil concerns.

Fuller and Bown (1975) extended the teacher-concerns model from Fuller's (1969) initial work as a tool to help preservice and in-service teachers identify and accomplish their educational and professional goals. Teachers' concerns were considered indicators of their developmental needs. Fuller and Bown (1975) suggested that teachers linearly identified three stages of concerns during their development: self-survival (self), teaching situation (task), and pupil (student-impact). Self-survival is the concern for one's adequacy as a teacher, classroom management, and the opinions of others. Teaching situation involves concern for time management, teaching methods, and available resources. Student concerns include a teacher's awareness of the students' outcomes and learning needs. Fuller and Bown proposed that teachers would identify new concerns in addition to those already identified in other stages as a result of improvement. Furthermore, less experienced teachers would have more self-concerns than veteran teachers, but veteran teachers would identify more task and student concerns than less experienced teachers. The authors did not specify if stages were distinct or overlapping.

Fuller and Bown's (1975) suggestion that teachers' concerns develop linearly has been met by other authors with mixed results. Research undertaken using quantitative (Marso \& Pigge, 1989; Pigge \& Marso, 1987, 1997; Ralph, 1993) and qualitative (Calderhead \& Robson, 1991; Hoy \& Woolfolk, 1990; Kagan \& Tippins, 1991; 
Weinstein, 1990) methods have substantiated the concerns model. Other researchers have found conflicting results with the linear development of teachers' concerns. For instance, Burn, Hagger, Mutton, and Everton (2000) reported 25 English student teachers to have high initial levels of concern for student performance at the beginning of student teaching, but they lacked clear development of concerns identification. Similarly, Weinstein (1990) reported a lack of change among preservice teachers' concerns during one semester of elementary field experiences. Participants emphasized affective and interpersonal issues but rarely commented on student performance concerns. Miksza and Berg (2013) discussed that the discrepancies among the findings of studies involving Fuller and Bown's (1975) model may be due to limited data collection time, the absence of mediating psychological constructs such as motivation, or failure to examine the impacts of contextual change on participants' beliefs across studies.

The Fuller and Bown model has been used to evaluate the development of preservice music teachers. A linear change was found in the teaching concerns of student teachers (Broyles, 1997; Yourn, 2000), pre-collegiate music teacher program participants (Miksza \& Austin, 2010), and preservice teachers before- and-after their student teaching experience (Killian, Dye, \& Wayman, 2013). Other researchers have found no shift in preservice teacher concerns. Despite exploratory interventions to change three music student teachers' focus during guided reflections, Coleman (1999) found no change from self-survival concerns to task or student-impact concerns over a twelve-week period. Campbell and Thompson (2007) investigated the concerns of 1,121 preservice music teachers from 16 U.S. colleges and reported participants' concerns did not change linearly with experience. Participants at all levels of professional development identified 
high levels of student impact concerns, followed by self and task concerns, respectively. The authors suggested that the cross-sectional and self-report nature of the survey, general rather than domain-specific concerns represented in the items, and participants' tendency to report "idealized" concerns may have led to contradictions with the concerns model.

Other researchers have proposed that preservice music teachers' concerns may not develop linearly in stages due to contextual and multidimensional factors. Miksza and Berg (2013) studied instrumental preservice teachers' concerns for 1.5 years, finding that participants' concerns changed from basic teaching abilities and professionalism to context-specific issues of teaching strategy and student learning. However, the number of participants' student and task concerns increased after a field placement change during their student teaching (e.g., secondary to elementary setting). The authors suggested that preservice teacher concerns may be linked to the level of familiarity an individual has in their setting. Berg and Miksza (2010) reported contextual factors such as prior teaching experience, grade level, and ensemble setting may also influence preservice teacher concerns. Results indicated participants' concerns did not necessarily change linearly, but rather consistently formed clusters in categories. Similarly, Powell $(2014,2016)$ found that preservice teachers had clusters of concerns during peer- and field-teaching experiences. These varying results suggest further investigation of teaching concerns is needed. Perhaps by studying how preservice and in-service teachers' concerns are influenced, we may better understand the contextual factors that relate with preservice teachers' concerns. Efficacious beliefs have been found to associate with teachers concerns in non-academic settings, therefore examining the beliefs of music teachers 
could provide support for addressing teachers' concerns as part of their pedagogical and efficacious development (Evans \& Tribble, 1986; Pyper, 2014).

\section{Conclusion}

Self-efficacy is influenced greatly by enactive mastery experiences. Successful teaching experiences that result in student improvement are more likely to improve teacher efficacy than unsuccessful teaching experiences. Instrumental teachers that set measurable and proximal objectives for their students in the rehearsal setting can positively impact student achievement. Providing accommodations for students such as modified procedures or materials may also improve their chances of accomplishing identified goals. During a rehearsal, teachers can use effective teaching behaviors to control student behavior and improve student performance such as frequent and deliberate eye contact, providing specific and concise feedback that is accurate to students' performance needs, and varying their voice inflection and physical proximity to the ensemble. Instrumental teachers can also attend professional development and enroll in graduate coursework that afford them pedagogical experiences and supportive instructor feedback. Observations of peers with abilities similar to one's own can also improve efficacious beliefs so long as teachers approach the experience with a growth mindset, as opposed to a competitive one. Cultivating teachers' self-efficacy by refining pedagogical approaches may lead to more positive feedback from mentors and instructors and less anxiety towards self- and teaching-task behaviors, thus turning teachers' focus to student outcomes.

Although efficacy beliefs are influenced by previous experiences and one's emotional state, there are numerous contextual and psychological factors that are 
influential, including knowledge, student and school demographics, and competence for a task (Usher \& Pajares, 2008). Further investigations into the interactions of these factors would contribute to our understanding of instrumental teachers' effectiveness and its influence on student achievement. Teacher self-efficacy and its sources has been examined thoroughly in non-music contexts, but few researchers have studied the construct as it relates to instrumental teachers. Future investigations of instrumental teachers' self-efficacy could include (a) how source influences may change over time, (b) relationships between effective teaching behaviors and the self-efficacy of instrumental directors, and (c) how years of experience relate to instrumental directors' self-efficacy for teaching strategies. Researchers could also investigate the experiences that influence preservice instrumental teachers' self-efficacy. Preservice music teachers' self-efficacy has been studied in relation to their experiences during the first year of study (Prichard, 2017), classroom management training (Bergee, 2002), and field-teaching (Austin \& Miksza, 2012), but few researchers have investigated qualitatively the experiences and contextual factors that preservice instrumental teachers identify as affecting their selfefficacy and concerns for teaching. Studying preservice teachers' concerns may be helpful in order to identify experiences that impact anxiety and efficacious beliefs.

The cyclical nature of teachers' efficacy makes their behavioral choices important for students' success (Tschannen-Moran et al., 1998). Teachers that demonstrate efficacious behaviors, such as providing frequent, specific feedback and assigning measurable performance goals in rehearsal, have the potential to affect their teaching behaviors, motivation, and professional dispositions. Moreover, improved teachers' self- 
efficacy can lead to improved student behavior, motivation, self-efficacy, and achievement (Woolfolk Hoy \& Davis, 2006). 


\section{Chapter Three}

\section{Examining Relationships Among Concert Band Directors' Self-Efficacy for Teaching Strategies, Its Sources, and Effective Teaching Skills}

Researchers have suggested that teacher self-efficacy (i.e., a teacher's belief in one's ability to bring about change in student learning and behavior) may have important influences on student and teacher outcomes (Bandura, 1997; Tschannen-Moran \& Woolfolk Hoy, 2001). Bandura (1997) proposed that self-efficacy was influenced by four sources of information: (a) enactive mastery experiences (successful and unsuccessful task experiences), (b) verbal persuasions (feedback from others), (c) vicarious experiences (observations of others with similar abilities), and (d) physiological state (psychological and physical). The cyclical nature of student performance informing teachers' approaches can have important effects on learning outcomes and behavior (Tschannen-Moran, Woolfolk Hoy, \& Hoy, 1998). For example, successful student mastery experiences can improve teacher effort and motivation, which leads to better student performance and greater teacher efficacy. The opposite can also be true. Woolfolk Hoy and Davis (2006) proposed a framework in which teacher self-efficacy affects both student and teacher outcomes directly, indirectly, or relationally. Over time, teacher self-efficacy can impact students' self-efficacy (Anderson, Green, \& Loewen, 1988; Ross, Hogaboam-Gray, \& Hannay, 2001), motivation (Midgley, Feldlaufer, \& Eccles, 1989), self-regulation (Woolfolk Hoy \& Davis, 2006), and academic achievement (Ashton \& Webb, 1986; Moore \& Esselman, 1992; Muijs \& Reynolds, 2002; Ross, 1992). It is evident that teacher self-efficacy can influence student learning and behavior. 
Relationships appear to exist between the self-efficacy of teachers and their pedagogical approaches. Highly efficacious teachers implemented more activity-based teaching strategies (Czerniak \& Schriver-Waldon, 1991; Riggs \& Enochs, 1990), used cooperative learning techniques (Dutton, 1990), and were more willing to try new teaching methods to meet individual student needs (Allinder, 1994; Berman, McLaughlin, Bass, Pauly, \& Zellman, 1977; Cousins \& Walker, 2000) than teachers with lower efficacy. Teachers with high efficacy were also less critical of students who made errors (Ashton \& Webb, 1986) and worked longer with students who were struggling (Gibson \& Dembo, 1984) than less efficacious teachers. Ross (1998) concluded that teachers with higher efficacy beliefs set higher goals and were more persistent, resulting in "greater classroom success and these mastery experiences...contribute to higher expectations" (p. 57).

Teacher self-efficacy may also affect one's own pedagogical behaviors and beliefs. In a meta-analysis of teacher efficacy studies, Klassen and Tze (2014) found teacher self-efficacy and personality to have a small but significant effect on teacher effectiveness. Highly efficacious teachers experimented with instructional materials and displayed greater ability to plan, organize, and teach the whole class for longer periods of time (i.e., direct teach) than those with lower efficacy (Allinder, 1994; Muijs \& Reynolds, 2001). Efficacious teachers reported higher levels of commitment towards teaching (Coladarci, 1992) and may be more likely to remain in the teaching profession than less efficacious teachers (Burley, Hall, Villeme, \& Brockmeier, 1991; Glickman \& Tamashiro, 1982). Klassen and Chiu (2010) found that greater job satisfaction related to greater efficacy for classroom management and teaching strategies, whereas lower job 
satisfaction and teaching efficacy was influenced by greater classroom stress. The authors of the study also reported efficacy for classroom management and teaching strategies positively influenced job satisfaction. Findings that effective teaching strategies, commitment, and job satisfaction are related to high levels of teacher self-efficacy may indicate the need to develop preservice and professional teachers' behaviors.

In addition to teachers in general education settings, researchers have examined the efficacious beliefs of music teachers. Wagoner (2011) found that $\mathrm{K}-12$ music teachers' commitment to teaching was moderately correlated with their efficacious beliefs. Commitment and efficacy also have been studied in relation to beginning music teachers' mentorship programs, although neither were influenced by the perceived effectiveness of the mentor (Koerner, 2017). Music teachers with reported high levels of school and classroom efficacy could be less at risk for attrition and migration, possibly due to the administrative and parental support they receive (Hancock, 2008). Teachers' perceptions of support were indicative of efficacy beliefs among non-music teachers as well (Woolfolk Hoy \& Burke-Spero, 2005). Perhaps these sources of support provide positive verbal persuasions for teachers that is reflected in their efficacy for teaching.

The sources of self-efficacy have been studied among general education teachers (Tschannen-Moran \& Johnson, 2011; Tschannen-Moran et al., 1998; Woolfolk Hoy \& Burke-Spero, 2005), but few have examined the ways that music teachers' self-efficacy is influenced. The relative effect of specific sources on teacher efficacy may change over time, particularly among novice teachers who have fewer mastery teaching experiences (Tschannen-Moran et al., 1998). Contextual factors such as gender, ethnicity, academic ability, academic grade-level, and academic subject can also influence the strength of 
efficacious sources (Usher \& Pajares, 2008). Still, it seems that mastery experiences have the most effect on beliefs across academic domains (Bandura, 1997; Hendricks, 2014; Usher \& Pajares, 2008). By better understanding how the sources influence music teachers' self-efficacy, music teacher educators may provide better preparation that impacts teachers' confidence in the classroom.

Researchers studying relationships between music teacher self-efficacy and years of experience (i.e., mastery experiences) have found mixed results. The self-efficacy of K-12 music teachers (Wagoner, 2011) and instrumental and vocal teachers (Biasutti \& Concina, 2018) were found to correspond with years of teaching experience. However, high school band directors (Regier, 2018) and beginning music teachers in mentorship programs (Koerner, 2017) did not hold higher self-efficacy beliefs as a result of teaching experience. Similar varied results have been found in studies of general education teachers. For example, Tschannon-Moran and Johnson (2011) found that years of teaching did not significantly influence teacher self-efficacy among a sample of elementary and middle school teachers. However, Klassen and Chiu (2010) reported that general education teacher self-efficacy improved from the 1st-year to approximately the 23rd-year, but then declined afterwards. Late career teachers may replace feelings of motivation with those of serenity or even disengagement (Huberman, 1989). Investigating how self-efficacy and its sources are influenced by years of experience could provide insight about teachers' efficacious development over time.

Although researchers have studied how the self-efficacy of general education teachers may relate to source influences and professional outcomes, little is known about these relationships among music educators, particularly concert band directors. Teaching 
behaviors and skills related to effective teaching have been studied among high school band directors (MacLeod \& Walter, 2011; Miksza, Roeder, \& Biggs, 2010), but relationships between the behaviors and director self-efficacy were not examined. Considering the contextual nature of efficacious beliefs and the pedagogical skills needed to teach in ensemble settings, it seems appropriate to investigate how director selfefficacy is influenced and whether differences relate with their teaching behaviors. Music teacher educators could use results related to effective teaching behaviors to guide the development of course content and teaching field experiences that might improve preservice teacher self-efficacy. Identifying how different kinds of experiences influence directors at different stages of their career may inform those charged with designing professional development opportunities about in-service directors' efficacious needs.

The purpose of this study was to investigate high school concert band directors' self-efficacy for teaching strategies and its sources. A secondary purpose was to investigate possible relationships between directors' self-perceptions of effective teaching and self-efficacy. The research questions included: (1) How much influence do mastery experience, vicarious experience, verbal persuasion, and physiological state have on concert band directors' self-efficacy for teaching strategies? (2) Does concert band directors' self-efficacy for teaching strategies or its sources differ by years of teaching experience? (3) What relationships, if any, exist between concert band directors' selfefficacy for teaching strategies and their self-rated ability for effective teaching skills? 


\section{Method}

\section{Participants}

National Association for Music Education (NAfME) members who identified as high school (grades 9-12) concert band directors were invited to participate in this study. I conducted an a priori power analysis using $G^{*}$ Power 3.1.9.2 software (Faul, Erdfelder, Lang, \& Buchner, 2007) to identify the minimum sample size with an acceptable level of statistical power to identify a small effect (Cohen, 1992). The results of the power analysis indicated a minimum sample size of 42 based on a linear multiple regression test and 246 for an ANOVA test (input parameters included a projected effect size of $f=.20$, $\alpha=.05$, and a power level $[1-\beta]$ of .8).

An assistant at the National Association for Music Education (NAfME) sent an invitation e-mail message to 11,937 high school band directors on my behalf upon project approval by the Society for Research in Music Education (SRME) Executive Committee and the payment of a fee. An email invitation to potential participants included IRBapproved consent information, the purpose and description of the study, and an electronic link to the survey. A reminder email was sent one week after delivery of the first email invitation. A total of 848 (7.10\%) individuals responded to the invitation. After removing outlier self-efficacy for teaching strategies scores (z-score > 3.29) (Field, 2013) and nonconcert band teachers from the dataset, I identified 610 acceptable responses for analysis.

Respondents $(N=610)$ were mostly men $(72.6 \%)$, and ages ranged from 22 to 80 years $(M=41.25, S D=11.85)$. Most participants had completed their master's degree $(61.3 \%)$, whereas others completed their bachelor's $(33.7 \%)$ or doctorate $(5.0 \%)$. Respondents reported their years of high school concert band teaching experience $(M=$ 
$14.56, S D=10.97)$, with experiences ranging from 1 to 53 years. Most were full-time teachers $(96.9 \%)$. Band directors reported teaching at elementary (19.3\%), middle (52.7\%), or high (99.6\%) schools, and responses indicated that many teachers worked at two or more levels. Participants worked at public $(88.8 \%)$, private $(8.8 \%)$, or charter schools $(2.4 \%)$ with enrollments ranging from 11 to 7,000 students $(M=944.32, S D=$ 759.79) in rural (49.8\%), suburban (42.3\%), or urban (7.9\%) settings. Directors indicated their NAfME region as Eastern (28.6\%), North Central (22.4\%), Northwestern (10.1\%), Southern (17.9\%), Southwestern (13.1\%), or Western (8.0\%).

\section{Measures}

\section{Concert Band Directors' Self-Efficacy for Teaching Strategies Scale. I}

adapted a 4-item scale designed by Tschannen-Moran and Woolfolk Hoy (2001) to measure concert band directors' self-efficacy beliefs for teaching strategies. Items for the self-efficacy measure were preceded by the stem "In a concert band setting, I can ..." and rated according to strength of confidence on a scale from 0 (not confident) to 10 (highly confident). A sample item included "provide an alternative explanation or example when students are confused." The internal consistency of the scale was high ( $\alpha$ $=.85$ ). See Appendix $\mathrm{D}$ for the self-efficacy for teaching strategies scale.

Sources of Self-Efficacy for Concert Band Teaching Scale. The influence of each source on concert band directors' self-efficacy for teaching was collected by using a scale adapted from previous measurements of the sources of music student performance self-efficacy (Zelenak, 2015) and student math self-efficacy (Usher \& Pajares, 2006). Participants rated their level of agreement on 24 items using a Likert-type scale anchored by 0 (strongly disagree) and 10 (strongly agree). Zelenak (2015) modified his scale from 
a measure designed by Usher and Pajares (2006), which was found to be highly reliable, valid, and invariant across gender, ethnicity, and ability level. Two examples of these modified items included "People have told me I have a talent for teaching concert band" and "I have always been good at teaching concert band." The internal consistency of the scale was excellent $(\alpha=.92)$. See Appendix E for the sources of self-efficacy scale.

Effective Teaching Skills. Participants rated their level of agreement to 10 items on a Likert-type scale with anchors of 0 (not effective) and 10 (highly effective). I adapted the items from a list of teachers' previously-reported highest-rated effective teaching skills (Teachout, 1997) that were also used in research about effective band director skills (Miksza, Roeder, \& Biggs, 2010). Items included "Maintain excellent classroom management and procedures" and "Maximize students' time on task." A list of the effective teaching skills is found in Appendix F.

\section{Procedures}

I created an electronic survey using Qualtrics, an online survey program. To establish content validity, three music education researchers with previous experience teaching high school concert band were asked to review the items. Edits that were made according to the reviewers' recommendations included increasing the level of specificity for identified items and modifying the survey layout. Eleven graduate students who were enrolled in a measurement and evaluation course also provided feedback about the survey. I clarified the wording of the item about years of high school teaching experience based on their feedback.

The first page of the electronic survey contained the purpose and description of the investigation, IRB information, and a notice of consent. The next sections of the 
survey included the Concert Band Directors' Self-Efficacy for Teaching Strategies Scale and the Sources of Self-Efficacy for Concert Band Teaching Scale, respectively. The third section was designed to collect participants' self-perceptions about effective teaching skills. Concert band directors entered demographic information on the final section of the survey. See Appendix G for demographic items.

\section{Results}

I calculated the means and standard deviations for concert band directors' selfefficacy for teaching strategies (BDSETS) scores and each source of self-efficacy. A BDSETS score for each participant $(N=610)$ was generated by adding their self-reported confidence levels for the four representative scale items, resulting in a scale that ranged from 4 to $44(M=37.86, S D=4.77)$. The source of self-efficacy score was the sum of the six related items, resulting in scores that could range from 6 to 66. Band directors' responses were highest for physiological state $(M=59.01, S D=5.87)$, followed by verbal persuasion $(M=58.14, S D=7.53)$, vicarious experience $(M=57.94, S D=7.15)$ and mastery experience $(M=55.92, S D=5.96)$. Descriptive statistics for self-efficacy items are found in Table 1.

Table 1

Means and Standard Deviations of Self-Efficacy Variables

\begin{tabular}{lccccc}
\hline Variable & $N$ & $M$ & SD & Skew & Kurtosis \\
\hline BDSETS $^{\mathrm{a}}$ & 610 & 37.86 & 4.77 & -0.43 & -0.72 \\
Mastery experience $^{\mathrm{b}}$ & 606 & 55.92 & 5.96 & -0.46 & -0.28 \\
Verbal persuasion $^{\mathrm{b}}$ & 603 & 58.14 & 7.53 & -0.94 & 0.16 \\
Vicarious experience $^{\mathrm{b}}$ & 603 & 57.94 & 7.15 & -1.14 & 1.54 \\
Physiological state $^{\mathrm{b}}$ & 605 & 59.01 & 5.87 & -0.84 & 0.10 \\
\hline
\end{tabular}

Note. ${ }^{\text {a }}$ Possible range from 4 to $44 .{ }^{\mathrm{b}}$ Possible range from 6 to 66 . 
I conducted 10 correlation analyses to examine how participants' self-efficacy for teaching strategies related with its four sources. Spearman's rho test was used to calculate correlations due to violating the assumption of normality needed to use Pearson's test. Correlations $\left(r_{\mathrm{s}}\right)$ ranged from .64 (mastery experience and verbal persuasion) to .32 (BDSETS and vicarious experience). All were significant at the .001 level. (See Table 2 for complete correlation statistical information).

Table 2

Spearman's Rho Correlations Among Self-Efficacy Variables

\begin{tabular}{lllll}
\hline Variable & 2 & 3 & 4 & 5 \\
\hline 1. BDSETS & $.53^{*}$ & $.51^{*}$ & $.32^{*}$ & $.43^{*}$ \\
2. Mastery experience & & $.64^{*}$ & $.45^{*}$ & $.62^{*}$ \\
3. Verbal persuasion & & & $.46^{*}$ & $.50^{*}$ \\
4. Vicarious experience & & & $.44^{*}$ \\
5. Physiological state & & & & 1.00 \\
\hline Note. ${ }^{*} p<.001$ & & & &
\end{tabular}

In order to predict band directors' self-efficacy for teaching strategies from its four sources, I used a multiple regression analysis. Assumptions of homoscedasticity, independence of the errors, and multicollinearity were met. Following a significant Shapiro-Wilk test $(p<.05)$, bootstrapped samples were used to accommodate for the violation of normality. After accounting for all four of Bandura's (1997) theorized sources of self-efficacy, I found mastery experience $(b=.27)$ to be the strongest, significant predictor of BDSETS, followed by verbal persuasion $(b=.12)$ and physiological state $(b=.10), R^{2}=.32, F(1,570)=10.08, p<.001$. Vicarious experience did not significantly predict efficacious beliefs. See Table 3 for regression data. 
Table 3

Multiple Regression Models Predicting Concert Band Directors'Self-Efficacy for Teaching Strategies by Career Stage

\begin{tabular}{|c|c|c|c|c|c|}
\hline Predictor & $b$ & $S E B$ & $\beta$ & $p$ & $\operatorname{adj} R^{2}$ \\
\hline Total BDSETS $(n=574)$ & & & & & .31 \\
\hline Mastery experience & .27 & .04 & .34 & .001 & \\
\hline Verbal persuasion & .12 & .03 & .19 & .001 & \\
\hline Physiological state & .10 & .04 & .12 & .012 & \\
\hline Early career $(n=186)$ & & & & & .23 \\
\hline Mastery experience & .26 & .06 & .36 & .001 & \\
\hline Verbal persuasion & .10 & .05 & .17 & .028 & \\
\hline $\operatorname{Mid}$-career $(n=254)$ & & & & & .22 \\
\hline Mastery experience & .17 & .07 & .19 & .022 & \\
\hline Verbal persuasion & .12 & .05 & .20 & .020 & \\
\hline Physiological state & .15 & .05 & .18 & .004 & \\
\hline Late career $(n=139)$ & & & & & .27 \\
\hline Mastery experience & .31 & .10 & .35 & .001 & \\
\hline Verbal persuasion & .15 & .07 & .24 & .025 & \\
\hline
\end{tabular}

Note. Results based on 1000 bootstrap samples.

Based on prior research concerning teachers' career stages (Day \& Gu, 2007; Huberman, 1989), participants were assigned to one of three groups depending on their years of concert band teaching experience: (a) early career ( $1-7$ years, $n=206)$, (b) midcareer ( $8-23$ years, $n=263)$, and (c) late career (more than 23 years, $n=139$ ).

Efficacious beliefs were then analyzed among career stages. Because Levene's $F$ test revealed the homogeneity assumption of normality was not met $(p=.014)$, the Welch's $F$ test was used. Results of a one-way ANOVA indicated a significant, large effect of career stage on self-efficacy for teaching strategies, Welch's $F(2,365.72)=71.45, p<.001, \eta^{2}$ $=.18$. Post-hoc comparisons using the Games-Howell procedure for unequal variances indicated that late career band directors $(M=40.39, S D=3.77)$ had significantly higher self-efficacy $(p<.001)$ for teaching strategies than mid-career $(M=38.56, S D=4.57)$ and early career directors $(M=35.21, S D=4.39)$, with effect sizes $(d)$ of .44 and 1.27 , 
respectively. Additionally, mid-career directors had significantly higher self-efficacy than early career directors $(p<.001, d=.75)$.

I conducted multiple regression modeling to examine how the influence of each source on directors' self-efficacy for teaching strategies differed by career stage. Bootstrapped samples were again used following a violation of the normality assumption. Mastery experience was the strongest predictor of BDSETS at all career stages $(p<.05)$. Verbal persuasion also was a significant predictor of BDSETS at each career stage whereas physiological state significantly predicted mid-career directors' efficacy. Vicarious experience did not significantly predict efficacious beliefs for any career stage. Table 3 contains career stage regression data.

In order to compare the self-reported effective teaching skills scores between higher self-efficacy directors $(n=305)$ and lower self-efficacy directors $(n=300)$, I split the sample at the median BDSETS score $(M d n=38.50)$. The number of participants in each group differs due to incomplete effective teaching skills data. Comparisons were made using independent samples $t$-tests with a Bonferroni adjustment due to multiple comparisons. All paired samples violated the equal variances assumption; therefore, equal variances were not assumed. Results indicated that all comparisons between these two groups of directors were significant $(p<.001)$ with effect sizes greater than $d=.55$. The largest disparity between the higher self-efficacy group and the lower self-efficacy group was their self-reported effectiveness to "present a lesson with clarity," $t(559.70)=$ $12.25, p<.001, d=.99$, followed by "motivating students," $t(560.65)=11.31, p<.001$, $d=.92$. The smallest effect size found was for "frequently making eye contact with 
students," $t(555.53)=-6.90, p<.001, d=.56$. See Table 4 for complete effective teaching behaviors $t$-test results.

Table 4

Effective Teaching Skills t-Test Results Between Higher and Lower Self-Efficacy Groups

\begin{tabular}{|c|c|c|c|c|c|c|}
\hline \multirow[b]{2}{*}{ Teaching skills } & \multicolumn{2}{|c|}{ Higher Self-Efficacy } & \multicolumn{2}{|c|}{ Lower Self-Efficacy } & \multirow[b]{2}{*}{$t$} & \multirow[b]{2}{*}{$d$} \\
\hline & $M$ & $S D$ & $M$ & $S D$ & & \\
\hline $\begin{array}{l}\text { Present a lesson with } \\
\text { clarity }\end{array}$ & 9.91 & 0.95 & 8.80 & 1.25 & $-12.25 *$ & .99 \\
\hline Motivating students & 9.82 & 1.09 & 8.65 & 1.42 & $-11.31 *$ & .92 \\
\hline $\begin{array}{l}\text { Maintain student } \\
\text { behavior }\end{array}$ & 9.95 & 1.20 & 8.67 & 1.60 & $-11.11 *$ & .91 \\
\hline $\begin{array}{l}\text { Maintain classroom } \\
\text { management and } \\
\text { procedures }\end{array}$ & 9.81 & 1.16 & 8.58 & 1.62 & $-10.73 *$ & .87 \\
\hline $\begin{array}{l}\text { Maximize students' time } \\
\text { on task }\end{array}$ & 9.81 & 1.18 & 8.69 & 1.43 & $-10.53 *$ & .85 \\
\hline $\begin{array}{l}\text { Maintain an effective } \\
\text { rehearsal pace }\end{array}$ & 9.88 & 1.16 & 8.79 & 1.49 & $-10.01 *$ & .82 \\
\hline $\begin{array}{l}\text { Employ a positive } \\
\text { approach to } \\
\text { rehearsals }\end{array}$ & 10.11 & 1.03 & 9.17 & 1.30 & $-9.84 *$ & .80 \\
\hline $\begin{array}{l}\text { Involve students in the } \\
\text { learning process }\end{array}$ & 9.90 & 1.23 & 8.88 & 1.45 & $-9.35^{*}$ & .76 \\
\hline $\begin{array}{l}\text { Work with students of } \\
\text { difference ages and } \\
\text { abilities }\end{array}$ & 10.46 & 0.91 & 9.62 & 1.28 & $-9.27 *$ & .76 \\
\hline $\begin{array}{l}\text { Frequently make eye } \\
\text { contact with students }\end{array}$ & 10.33 & 1.22 & 9.52 & 1.62 & $-6.90 *$ & .56 \\
\hline
\end{tabular}

Note. Groups were created by splitting the self-efficacy for teaching strategies scores at the median. ${ }^{*} p<.001$

\section{Discussion}

The purpose of this study was to investigate high school concert band directors' self-efficacy for teaching strategies and its sources. Directors' self-efficacy for teaching strategies were most influenced by mastery experiences, followed by verbal persuasions, physiological state, and vicarious experiences, in order of importance. These results are similar with those from previous studies in general education (Lopez \& Lent, 1992; 
Matsui, Matsui, \& Ohnishi, 1990; Tschannen-Moran et al., 1998; Usher \& Pajares, 2006; Woolfolk Hoy \& Burke-Spero, 2005) and music settings (Hendricks, 2014; Zelenak, 2015). Bandura (1997) believed previous successes and failures were powerful predictors of self-efficacy. In educational settings, these experiences may be even more important due to the reciprocal nature between students' relative success creating new mastery experiences for teachers that can impact efficacious beliefs (Tschannen-Moran \& McMaster, 2009; Woolfolk Hoy \& Davis, 2006). Teachers that acquire successful mastery experiences likely improve their opportunity to receive affirmative feedback, resulting in greater confidence and efficacy for concert band teaching tasks.

Participants who reported greater self-efficacy for teaching strategies also rated themselves as more confident for using effective teaching skills. Higher and lower efficacy groups' teaching skills scores differed the most for "presenting a lesson with clarity," suggesting the perceived difficulty level of the skill. Scores for "motivating students" and "maintaining student behavior," both highly valued skills for successful teaching among music teachers as reported in previous studies (Miksza, Roeder, \& Biggs, 2010; Teachout, 1997), also significantly differed between efficacy groups. Higher efficacy teachers related with higher scores on skills associated with teacher intensity, including "maintaining classroom management," "maintaining an effective rehearsal pace," and "presenting a lesson with clarity" (Madsen \& Geringer, 1989). Intensity behaviors were indicative of effective teaching in examinations of preservice elementary teachers (Cassidy, 1990), in-service elementary teachers (Madsen, 2003), and instrumental student teachers (Madsen et al., 1992). Efficacious directors may feel confident in their ability to improve student performance by applying effective 
pedagogical strategies specific to their learners needs while motivating and controlling student behavior. Improving skills and behaviors for which directors feel less confident could improve their self-efficacy and enable them "to set higher goals for themselves and others...and learn new methods that contribute to higher student achievement" (Ross, 1998, p. 58). Videotaping rehearsals, receiving peer or mentor feedback, or asking students about their learning needs could provide insight for directors' identification of skills that need improvement (Powell, 2016; Stanley \& Madsen, 1991; Worthy, 2005).

Concert band directors' self-efficacy for teaching strategies scores were associated with experience level. This result is consistent with previous findings among K-12 music teachers (Wagoner, 2011) and instrumental and vocal teachers (Biasutti \& Concina, 2018). That a larger efficacious difference existed between early and mid-career directors than between mid- and late-career directors supports Bandura's (1996) theory that efficacious beliefs are most impacted at the beginning of development and may be resilient to change once established. Therefore, it seems important to identify experiences that effect early career directors' self-efficacy due to the lasting impact that beliefs have on teachers' motivation and confidence (Klassen \& Chiu, 2010). Early career directors' self-efficacy was most predicted by their mastery experiences and verbal persuasions based on the results of current study. Consistent with previous recommendations, this result supports novice teachers' need for pedagogical and psychological mentorship and resources as they gain mastery teaching experiences (Koerner, 2018; Tschannen-Moran \& Woolfolk Hoy 2007). Specifically, mentorship in the form of "regular meetings, mutual observations, and formal and detailed teaching evaluations over multiple years" (Koerner, 2018, p. 206) may support the efficacy of early career directors. Fostering the 
self-efficacy of early career directors could improve their professional commitment and identity (Wagoner, 2011), and result in less teacher attrition and migration (Hancock, 2008).

Verbal persuasions for specific mastery experiences may be particularly helpful for directors who seek to improve their self-efficacy for teaching strategies. Researchers have reported that the qualities of feedback can change the influence of others' persuasions. For example, receiving feedback early in the learning process and after successfully performing a task can be important to efficacious beliefs (Schunk, 1984). However, improvements to self-efficacy from feedback can fade if effort does not produce desired results (Schunk \& Zimmerman, 2007). Furthermore, feedback that is unspecific or seemingly insincere may not have a lasting impact on self-efficacy, whereas support from respected individuals when trying new pedagogical strategies can provide the encouragement for directors to persevere when teaching becomes difficult (Bandura, 1997). Hancock (2008) found that support from administrators and parents related with music teachers' classroom efficacy. Similar investigations of concert band directors' classroom efficacy and support systems could reveal relationships with teaching approaches in the rehearsal hall. Other examinations into perceived quality of colleague and community support (Tschannen-Moran \& Hoy, 2007) might improve our understanding of how verbal persuasions influence directors' willingness to implement new pedagogical strategies and efficacious beliefs for teaching.

Among the three studied career stages, physiological state had a significant relationship with mid-career directors' self-efficacy only. Mid-career concert band directors - who have chosen to remain in the profession—likely have experienced 
impactful teaching episodes and received meaningful feedback, resulting in a strong physiological state. However, results of the current study indicated that the influence physiological state had on self-efficacy was not significant as directors continued to teach, possibly due to declining professional motivation and enthusiasm (Day \& Gu, 2007). Huberman (1989) suggested late career stage teachers experience a sense of serenity, where a lack of enthusiasm and energy is compensated with having a greater sense of confidence and self-acceptance, followed by a period of disengagement at the very end of their careers. Rather than being impacted by their emotions for teaching, late career directors' beliefs were predicted by a long career of impactful teaching experiences and the verbal persuasions of others. However, directors who lack motivation and enthusiasm for teaching, or maybe have anxiety or stress, may need to address professional expectations (Betoret, 2006; Schwarzer \& Hallum, 2008) or feelings of imposter phenomena (Clance, 1985; Sims \& Cassidy, 2018). Acknowledgement of imposter feelings (Sims \& Cassidy, 2018) or meditation practices (Diaz, 2018; Meiklejohn et al., 2012; Roeser et al., 2013) have the potential to improve concert band directors' physiological state and thus may improve efficacious beliefs for teaching tasks, especially among mid-career directors when such influences are most impactful.

Although vicarious experience had a small, significant correlation with efficacious beliefs and moderate correlations with the other sources of self-efficacy, it did not significantly predict directors' self-efficacy for teaching strategies. Other findings have indicated that vicarious experiences had little impact on general education teachers' self-efficacy (Gusky, 1984; Joyce \& Showers, 1988). Observational experiences are often part of workshops or graduate coursework, but the results of this study suggest such 
experiences may need to be supported by other efficacious sources. For example, undergraduate observational experiences have been found to impact preservice teachers' beliefs, most notably when experiences are structured and students have the opportunity to share their findings with classmates (Prichard, 2012). Conway (2012) suggested that teacher educators should provide students with contextual guidance and support during observations. Investigators also have stressed the importance of having a growth mindset during observations of peers, rather than a competitive one, to maximize the potential benefit from such experiences (Bandura, 1997; Schunk, 1987). Support and structure for in-service directors that is similar to those found in preservice coursework, while focusing on positive pedagogical strategies and professional attributes, could provide positive feedback and reflective practice that develops pedagogical efficacy in the rehearsal setting. Allowing time for observers and model teachers to discuss pedagogical strategies utilized in rehearsals may increase observers' confidence to apply new ideas in their own classrooms. Further support could be provided by having directors share videos of their teaching with mentor teachers in order to receive further guidance (Bautista, Wong, \& Cabedo-Mas, 2018).

Findings from this study suggest that developmental experiences may need to be evaluated to determine if they effectively impact concert band directors' self-efficacy. Directors frequently participate in professional development workshops in which clinicians provide pedagogical strategies (Stein \& Wang, 1988); however, results have indicated that such persuasions rarely make a lasting impression on efficacious beliefs (Guskey, 1989; Tchannen-Moran \& McMaster, 2009). Because mastery experiences are often the most predictive source of self-efficacy, workshops that include the opportunity 
to conduct ensembles with support and feedback from expert pedagogues could improve the impact that developmental experiences have on self-efficacy. Additional feedback sessions after workshop participation may increase the likelihood that teachers implement new teaching strategies in the classroom (Dolloff, 1996; Tschannen-Moran \& McMaster, 2009). These developmental approaches would also appear to transfer to graduate coursework settings. Identification of coursework that includes support for pedagogical strategy implementation, especially in settings where participants feel less efficacious, could improve teachers' confidence, effectiveness, and student achievement. Informal learning with colleagues can also improve teaching confidence. Tschannen-Moran and Johnson (2011) reported that general education teachers' participation in book clubs or teachers-as-readers groups related to feelings of confidence for engaging students in learning. Perhaps similar informal learning environments could provide experiences that influence directors' self-efficacy for teaching, such as community music ensembles or chamber groups with peers.

The generalizability of this study is limited by the population that was surveyed. Care should be taken when transferring the experiences of concert band directors to teachers of other band settings or choral and orchestra instructors. Although attempts to reduce response bias were made by ensuring participant anonymity throughout the survey, the sample of the current study may have reported higher self-beliefs than what might be expected among the actual population (Miksza \& Tan, 2015). Results indicated that mean scores for self-efficacy and its sources were mostly negatively skewed and the normality assumptions were not met. These results were accounted for by using robust tests to the normality assumption, all of which indicated significant differences between 
teachers' self-efficacy and career stages, and the influence the sources had on teachers' beliefs. Furthermore, effect sizes between higher efficacy and lower efficacy groups were large, suggesting that directors reported their beliefs honestly.

Concert band directors' self-efficacy is not only influenced by previous experiences and the physiological state associated with a presented task, but also by numerous contextual factors such as personal and school demographics, content knowledge, and competence for a task (Usher \& Pajares, 2008). Examinations into the influence that these factors have on directors' self-efficacy for teaching strategies could further our understanding of their beliefs. Considering that previous research results have indicated efficacious sources may influence females differently than males (Hendricks, 2014; Regier, 2018; Usher \& Pajares, 2008), attention should be given to the role of gender. Other variables to consider include the quality of preservice and professional development experiences, administrative support, job stress, and imposter feelings, as these have been found to affect the beliefs of teachers of varying levels and disciplines. Exploring how efficacious beliefs also influence music teachers in orchestra, choral, or general music settings will allow for meaningful comparisons across groups of teachers and ensembles. Results might further our understanding of how music teachers with different specialty areas develop at the preservice and in-service levels and could lead to music education classes and workshops that impact efficacious beliefs for all music teachers.

The results of this study indicated that self-efficacy and the influence of its sources change across time, in addition to strong relationships between self-efficacy for teaching strategies and effective teaching skills. As such, it is important that researchers 
continue to investigate the extent that directors' efficacious beliefs are influenced by prior experiences and those experiences' possible impact on teaching behaviors. Advancing the current investigation to examine the impact of teachers' self-efficacy on students' outcomes seems appropriate. Results could support the development of directors' selfefficacy as a means for improving students' motivation, self-regulation, self-efficacy, and performance achievement. 


\section{Chapter Four}

\section{A Case Study of Preservice Instrumental Teachers' Self-Efficacy and Concerns}

The experiences that preservice teachers have during their undergraduate coursework instill confidence in their teaching behaviors and abilities. Beliefs in one's ability to perform a given task (i.e., self-efficacy) are informed by the relative success of previous attempts, observing others with similar abilities, feedback from individuals, and the physiological state associated with the task (Bandura, 1997). Preservice teachers' self-efficacy develops early during undergraduate study when efficacy beliefs are most impressionable (Bandura, 1986; Martin, 1989), and likely increases over time (Hoy \& Woolfolk, 1990; Woolfolk Hoy \& Burke-Spero, 2005). Because they often have had fewer successful teaching experiences, preservice teachers' self-efficacy may be influenced differently than veteran teachers' (Tschannen-Moran, Woolfolk Hoy, \& Hoy, 1998). High levels of teacher self-efficacy have the potential to influence the use of teaching strategies such as cooperative learning techniques, activity-based instruction, and new teaching methods to meet students' needs (Allinder, 1994; Chacon, 2005; Cousins \& Walker, 2000; Dutton, 1990; Riggs \& Enochs, 1990), and professional dispositions such as personality, commitment, and job satisfaction (Allinder, 1994; Coladarci, 1992; Klassen \& Chiu, 2010; Klassen \& Tze, 2014; Muijs \& Reynolds, 2001). Teachers' self-efficacy has been found to relate with their students' motivation (Midgley, Feldlaufer, \& Eccles, 1989), self-efficacy (Anderson, Green, \& Loewen, 1988; Ross, Hogaboam-Gray, \& Hannay, 2001), self-regulation (Woolfolk Hoy \& Davis, 2006), and academic achievement (Ashton \& Webb, 1986; Moore \& Esselman, 1992; Muijs \& Reynolds, 2002; Ross, 1992). In sum, the development of preservice teachers'self- 
efficacy may impact their eventual teaching strategies, professional outlook, and their students' behavior and academics.

Preservice music teachers' self-efficacy can be formed by curricular experiences. Prichard (2017) examined the self-efficacy of preservice music teachers enrolled in an introductory music education course. Experiences that positively influenced participants' efficacious beliefs for teaching included individualized mentoring, peer teaching, and structured field observations. Bergee (2002) compared the effect of using two methods of instruction on preservice music teachers' classroom management efficacy. Preservice teachers' efficacious beliefs were improved by having participants view videotapes of cooperating teachers' rehearsals or by applying learned classroom management skills in the field. However, the gains of the field application group lasted longer than those of the video-only group.

Field teaching experiences can also develop undergraduate students' efficacious beliefs. Austin and Miksza (2012) explored classroom management efficacy, in addition to teacher strategy efficacy, among students in a pre-collegiate music recruitment program. At the end of a 12-week teaching experience, the high school student participants had higher social motivation, teacher identity, and classroom management efficacy scores than at the beginning of the experience. The authors also reported that teaching strategy efficacy was significantly linked to participants' teacher identity. Similarly, Barnes (1998) studied preservice teachers during a student teaching experience but found participants' efficacious beliefs to decline over the span of eight weeks. Participants' initial belief in their ability to control student learning and behavior may have been too high, resulting in a decrease over time (Woolfolk Hoy \& Burke-Spero, 
2005). Because there seems to be some disparity about how best to improve efficacious beliefs, qualitative investigations may provide important context about the development of preservice teachers' self-efficacy.

The efficacious beliefs of preservice music teachers might be better understood by examining the causes of their worries and anxiety. Teachers' perceived problems or worries have been defined as teacher concerns (Fuller, 1969). Fuller and Bown (1975) developed a teacher concerns model as a tool for helping preservice and in-service teachers identify and accomplish their professional goals. Teachers' concerns were considered indicators of their developmental needs. The researchers suggested that teachers identified three stages of concerns across their development: self-survival (self) to teaching situation (task) to pupil (student-impact). Self-survival is the concern for one's adequacy as a teacher, personality, and the opinions of others. Teaching situation involves concerns for time management, teaching methods, and available resources. Student-impact concerns include an awareness of student outcomes and learning needs. Fuller and Bown proposed that with pedagogical improvement, teachers would identify new concerns in addition to those already identified in other stages. Teachers with less experience would have more self-survival concerns than veteran teachers, whereas veteran teachers would identify more task and student-impact concerns than less experienced teachers.

Researchers have investigated whether or not teachers' concerns develop linearly, with mixed results. Whereas findings from several quantitative (Marso \& Pigge, 1989; Pigge \& Marso, 1987, 1997; Ralph, 1993) and qualitative (Calderhead \& Robson, 1991; Hoy \& Woolfolk, 1990; Kagan \& Tippins, 1991; Weinstein, 1990) studies have 
substantiated the Fuller and Bown's (1975) proposed concerns model, other researchers have found results that were not consistent with the linear development of preservice teachers' concerns. For instance, Burn, Hagger, Mutton, and Everton (2000) reported that 25 English student teachers had high initial levels of concern for student performance at the beginning of student teaching but lacked clear development of concerns identification over time. Similarly, Weinstein (1990) reported a lack of change among preservice teachers' concerns during one semester of elementary field experiences. Participants emphasized affective and interpersonal issues but rarely commented on student performance concerns. Discrepancies among studies exploring Fuller and Bown's model may have been a result of:

(a) the length of time used for data collection (e.g., too short to examine potentially longitudinal shifts in thinking), (b) the absence of other mediating variables (e.g., teacher's personality, teacher's motivation), or (c) the presence or lack of changes in context across studies (e.g., changes in the teaching environment or placement site) (Miksza \& Berg, 2013, p. 46).

The Fuller and Bown model also has been used to evaluate the development of preservice music teachers. A linear change was found in the teaching concerns of student teachers (Broyles, 1997; Yourn, 2000), pre-collegiate music teacher program participants (Miksza \& Austin, 2010), and preservice teachers before and after their student teaching experience (Killian, Dye, \& Wayman, 2013). Other researchers found no shift in preservice teacher concerns, however. Despite interventions to change three music student teachers' foci during guided reflections, Coleman (1999) found no change from self-survival to task or student-impact concerns over a twelve-week period. Campbell and 
Thompson (2007) investigated the concerns of 1,121 preservice music teachers from 16 U.S. colleges and reported that participants' concerns were not associated linearly with experience. Participants at all levels of professional development identified high levels of student impact concerns, followed by self and task concerns, respectively. The authors suggested that the cross-sectional and self-report nature of the survey, general rather than domain-specific concerns represented in the items, and participants' tendency to report "idealized" concerns may have led to contradictions with the concerns model.

Preservice music teachers' concerns may not develop linearly in stages due to contextual and multidimensional factors. Miksza and Berg (2013) studied instrumental preservice teachers' concerns for 1.5-years, finding that participants' concerns changed from basic teaching abilities and professionalism to context-specific issues of teaching strategy and student learning. However, participants' student and task concerns increased after a field-placement change during their student teaching (e.g., secondary to elementary setting). Preservice teacher concerns may be linked to the level of familiarity an individual has with the setting. Berg and Miksza (2010) reported that contextual factors such as prior teaching experience, grade level, and ensemble setting may also influence preservice teachers' concerns. Results of their research indicated that participants' concerns did not necessarily change linearly, but rather consistently formed clusters in categories. Similarly, Powell $(2014,2016)$ found that preservice teachers had clusters of concerns during peer- and field-teaching experiences. Further investigation into the contextual factors influencing preservice teachers' concerns may provide clarification about their development. 
The concerns of preservice music teachers may impact their self-efficacy for teaching. Individuals with lower self-efficacy for teaching have reported more selfsurvival concerns (Ghaith \& Shaaban, 1999; Pyper, 2014) and total number of concerns (Boz \& Boz, 2010) than did those with higher teaching efficacy. Ghaith and Shaaban (1999) suggested high efficacy teachers may feel less concerned about their teaching as a result of their personal efforts and ability to solve problems with experience. Although relationships seem to exist between teachers' self-efficacy and concerns (Boz \& Boz, 2010; Evans \& Tribble, 1986), few researchers have examined these attributes with preservice music teachers. Given the contextual nature of self-efficacy (Bandura, 1997) and teacher concerns (Miksza \& Berg, 2013), a qualitative investigation may enhance our understanding of preservice teachers' development and the experiences that improve their confidence for teaching. Therefore, the purpose of this study was to investigate the experiences and contextual factors that influence preservice instrumental music teachers' self-efficacy and concerns. Research questions included: (1) To what extent do preservice instrumental music teachers' concerns relate to their efficacious experiences? (2) How do preservice instrumental teachers' concerns change from pre-student teaching to student teaching? (3) What pre-student teaching experiences do participants most commonly believe inform their self-efficacy for teaching?

\section{Method}

I used a case study design for this qualitative inquiry. Case study methodology is used to "investigate a contemporary phenomenon in-depth and within its real-life context" (Yin, 2009, p. 18). Such investigations provide a rich understanding of the case by collecting many forms of data (Creswell, 2013) in order to build patterns and 
explanations (Yin, 2009). I examined preservice instrumental teachers' concerns and efficacious experiences during their pre-student teaching and student teaching experiences. Data for the study included a questionnaire, electronic journal (i.e., ejournal) entries, interviews, and my own researcher journal.

I solicited undergraduate music education students to participate in the study during a regularly-scheduled instrumental music methods class at a large Midwestern university. Four students agreed to participate and were provided a description of the study with an IRB-approved consent form. Participants included three males and one female, and their area of focus included band $(n=3)$ and orchestra $(n=1)$. Three participants were enrolled in their last semester of music education coursework and one participant was in the penultimate semester of coursework before student teaching. Prior to this semester, participants had completed one semester of elementary field experience and another of middle school field experience. Participants are referenced by pseudonyms to protect their identity.

\section{Participants}

Colton (age 23) was a fifth-year music education student that played trumpet in multiple university concert bands and the orchestra. In addition to directing bands, Colton furthered his conducting study with the orchestra director and had opportunities to lead that ensemble. Another teaching opportunity included giving private trumpet lessons to middle school students. His student teaching was in elementary school general music during this study.

Mary (age 22) was a fourth-year cello player in the orchestra and studying to be a music educator. She provided private cello lessons to area students and had experience 
teaching in a community youth string program. Her student teaching placement was with a secondary string program where she taught grades 6-12.

Austin (age 22), a fourth-year saxophonist, had experience playing in the wind ensemble and studio saxophone quartets at the university. In addition to his instructorassigned field experiences, Austin assisted with the instruction of a marching band during the summers. Austin student taught at in elementary school general music program during this study.

Steve (age 23) was a fifth-year trumpet player in the music education program. His student teaching placement was with an elementary general music instructor, and he also assisted with some of the after-school elementary band lessons. Previous teaching experiences outside of required university coursework included summer marching band instruction and giving private trumpet lessons to middle and high school students. Steve also had experience conducting in a summer ensemble affiliated with Drum Corps International.

During the initial phase of data collection, the participants were in their final field experience before starting their full-time student teaching placement. The preservice teachers taught twice weekly during a typical week, in a middle school or high school instrumental classroom in schools that were economically and/or racially diverse. Each field experience during this semester took place at a location for approximately two weeks and then changed to a new location. When not teaching, preservice teachers observed their peers' teaching but did not offer feedback to one another. However, feedback was received from the course instructor after each field teaching experience. Preservice teachers would then turn in a written reflection about their teaching episode. 
Participants completed their student teaching at separate schools with cooperating teachers who had taught at their schools between 7 and 15 years. All schools were in large suburban public school districts in the Midwest serving between 14,277 and 18,073 students. Each district had an approximately $25 \%$ minority student population. Participants' student teaching placements did not change during the course of data collection.

\section{Data Collection and Analysis}

Data collection took place over ten academic weeks (five weeks pre-student teaching and five weeks during student teaching). Data sources included a preservice teacher self-efficacy questionnaire, 10 e-journal entries, interviews after the student teaching experience, and my own researcher journal. Self-efficacy questionnaire items used to identify the sources of students' confidence to teach in an instrumental setting were modified from those used by Milner and Woolfolk Hoy (2003), and Zeldin and Pajares (2000) to reflect an instrumental teaching setting. The modified open-response questions included (a) What undergraduate teaching experiences contributed the most to your confidence for teaching instrumental music? (b) What observational experiences have improved your confidence to teach in an instrumental setting? (c) What do others say about your instrumental teaching abilities? and (d) How does instrumental teaching make you feel? Participants provided responses to questionnaire items once at the beginning of the study, before the e-journal data collection. Responses were analyzed using categorical aggregation to find patterns respective of each question (Creswell, 2013). 
Participants responded to e-journal prompts designed to collect information about their concerns and efficacious experiences. Entries were completed for five academic weeks during the pre-student teaching experience and five weeks during the student teaching experience. Participants provided written answers to the following questions at the end of each week: (a) What teaching concerns do you have for the coming week? (Fuller \& Bown, 1975), and (b) What experiences in class or the field have affected your confidence to teach during the past week? (Palmer, 2006). I used a codebook developed by Berg and Miksza (2010) to analyze preservice teachers' concerns. A self-survival concern category was used to identify personal characteristics involving teaching, including relationships with others, and relationships that related to the teaching environment. I assigned a task code to identify concerns for teaching strategy and content knowledge. Student-impact codes were used for concerns with student ability, knowledge, and affect. The in-class and field efficacious experiences were coded using deductive logic (Creswell, 2013), including the source of self-efficacy (enactive mastery experiences, vicarious experiences, verbal persuasions, and physiological state) and a subcategory (e.g., field teaching, professional teaching). A professional experience code was used to identify any teaching experiences that happened outside of a field or peer teaching experience.

To establish reliability of the self-efficacy questionnaire and e-journal data coding, an external evaluator and I independently coded all of the comments. I provided the external evaluator with a predetermined codebook to analyze the data sources (Creswell, 2013). Reliability of codes was calculated by dividing the number of agreements by agreements plus disagreements (multiplied by 100 to express it as a 
percentage), resulting in an inter-coder reliability of $96.36 \%$ for the questionnaire codes and $90.80 \%$ for the e-journal codes.

Focused interviews (Merton, Fiske, \& Kendall, 1990) with the participants were conducted after the five-week student teaching period. This type of interview protocol was used so that I could ask specific questions in order to corroborate certain facts based on participant responses to the self-efficacy questionnaire and e-journal items. Interviews lasted for approximately 12 minutes each and ranged from 8 to 15 minutes. Both another individual familiar with the project and I listened to the interviews independently. Based on the recommendations of Miles and Huberman (1994), we created start codes based on the research questions that were descriptive in nature (e.g., verbal persuasions, self concern) and then categorized codes into themes (e.g., field experiences, professional experiences). We then met and discussed our coding and categorization and resolved any discrepancies until we reached consensus (Denzin \& Lincoln, 2005).

I kept a journal of all interactions and discussions with the participants during the course of data collection. The journal included email correspondence, conversations from before-or-after student-teacher seminar meetings, field notes from student teaching observations, and conversations at rehearsals. A total of 31 journal notes were taken during the course of data collection. I provided an initial set of journal codes to an external evaluator to support or refine. We then met to re-examine the codes and resolved any disagreements until there was consensus.

\section{Trustworthiness}

Validity was achieved through triangulation, clarifying researcher bias, and using member checks (Huberman \& Miles, 1994). Source triangulation included using multiple 
sources of data (questionnaire, e-journals, interviews, and researcher journal) to develop an in-depth understanding of the cases being studied (Yin, 2009). I minimized researcher bias by discussing my previous experiences with the study participants. An individual other than myself lead the pre-student teaching experiences, including course instruction, assigning field placements, and giving field-teaching feedback (Merriam, 1998). I had taught the participants in an instrumental rehearsal methods course in a semester prior to this project, in addition to leading their student-teaching seminar meetings at the time of data collection. I also was the student teaching supervisor for three of the participants. This project was not discussed in the seminar meetings, nor did it have any bearing on class content because the seminar included non-participants. Although the participants knew of the project during data collection, their candor about teaching experiences and placements led me to believe they were open and honest with their answers. Participants could also clarify misinterpretations of information during their focused interview that happened after all other data were collected. Member checks (Lincoln \& Guba, 1985) at the end of data collection allowed participants the opportunity to review my coding and interpretations for accuracy and credibility. The participants did not offer any alterations.

\section{Findings \& Discussion}

Three themes emerged as a result of participants' responses from the questionnaire, e-journal, and interviews. Value of professional teaching experiences reflected preservice teachers' discussion of experiences outside of the undergraduate curriculum that impacted their confidence for teaching. Familiarity emerged as participants reported their changing beliefs as teaching placements changed across time. Finally, Changing and clustered concerns illustrated that, although participants' concerns 
changed over time, many of them were consistent among a limited number of pedagogical topics.

\section{Theme One: Value of Professional Teaching Experiences}

Professional teaching experiences refers to participants' identification of impactful pedagogical experiences on their confidence to teach. The codes that contributed to this theme included teaching private lessons, working with high school marching bands, non-curricular teaching, and teaching in community music programs.

Participants identified opportunities not associated with their undergraduate coursework, (i.e., professional teaching experiences) as having an influence on their teaching confidence prior to their student teaching experiences. Mary believed that helping small groups of students from a community youth string program increased her confidence to teach instrumental music "much more than any other teaching experience" (questionnaire). Mary further commented: "I think doing private lessons and string project, [being] responsible for my own students, that helped me [a] lot as well. I sort of got some skills" (interview). Steve shared similar thoughts regarding teaching experiences outside of the collegiate curriculum: "I worked with a marching band here [i.e., at his student-teaching placement] and I loved it. I really think that was way more real-world experience" (questionnaire). He went on to write, "I think field experience was great because I got immediate feedback on what I was doing, but as far as experience, I think that...outside stuff [professional experiences] was a bit more helpful for me in the long run."

The positive feedback that participants received about their ability to teach in professional instrumental settings also shaped their efficacious beliefs. For example, 
students' parents, students, and peers told Mary she was “competent, confident, and approachable when teaching small group cello and larger orchestra classes" (questionnaire). Colton also discussed his conducting confidence for leading ensembles in professional settings, remarking that others had told him that: "I have good confidence and podium presence while conducting/teaching" (questionnaire). These experiences occurred in settings where the participants had previous teaching success and prior knowledge about the students.

The physiological state that the participants attributed with teaching instrumental music in professional settings was positive. Participants felt like they were making a difference and having a positive impact on the lives of students. Austin remarked that "teaching instrumental music makes me feel like I am doing something worthwhile" (questionnaire), and Mary commented: "Teaching strings makes me feel useful and like I am making a difference in my students' lives, especially beginning students" (questionnaire). Teaching instrumental music was also fun for participants. "I will always feel that instrumental music is fun to teach!" Colton wrote in his questionnaire. Austin similarly referenced his enjoyment, writing that "Teaching instrumental music makes me feel good knowing that I can have fun when the students are having fun" (questionnaire).

Through early professional teaching experiences, participants had time to study students' learning needs and refine their instructional skills. Colton discussed how teaching trumpet lessons provided a valuable way to learn from mistakes and make pedagogical adjustments for the next lesson (interview). Austin similarly discussed why the time spent working with a marching band during the summer helped his teaching confidence: "Working with [marching band] students more frequently really helped 
me...figure out how I wanted to approach things; how I wanted to work through these kinds of things. Where field, you get one shot and then you're done" (interview). Professional experiences also provided preservice teachers the time needed to build rapport with students. Steve said the following about teaching high school marching band: "I really think that was way more real-world experience because...I got to meet kids and get to know them over the course of two years and really get to develop that teacher-student relationship with a lot of people" (interview).

Professional teaching experiences can provide a sense of authenticity to preservice teachers' pedagogical development. Preservice teachers may value the sense of autonomy when making pedagogical decisions and taking responsibility for student learning (Hourigan \& Scheib, 2009; Schmidt, 2010). Similar authentic teaching opportunities have been reported to have impacted preservice teachers' identity, classroom management efficacy, and teaching skills (Austin \& Miksza, 2012) and may have contributed to their overall pedagogical and psychological development (Paul, 1998; Paul et al., 2001). Cultivating preservice teachers' self-efficacy during undergraduate study may impact their teaching self-efficacy and identity later in their careers (Mulholland \& Wallace, 2001; Prichard, 2016; Regier, 2018; Woolfolk Hoy \& BurkeSpero, 2005).

\section{Theme Two: Familiarity}

The preservice teachers' self-efficacy was related to their concerns and changed with their familiarity in a teaching setting. The theme Familiarity included codes associated with the age group, ability level, or ensemble setting of the students being taught by the participants. Another code associated with the familiarity theme included 
consistency with the field teaching experience. After transitioning from a middle school to a high school band field placement during pre-student teaching, Austin said:

We're moving up from middle schools, where we have been working all semester to high school, where we will be working with their top concert band and jazz band. I am feeling a new level of depth and difficulty with the work and preparedness I must demonstrate with these higher-level musicians. (e-journal) Teaching more musically advanced students at the high school level also concerned Steve:

Although I can project a certain level of expertise and confidence in environments I am comfortable with, it is not as easy in environments that are new. At some point during this week I will be working with an accomplished high school wind ensemble. I'm hoping to portray the same level of expertise with this group that I can with a middle school band. (e-journal)

Participants expressed difficulties teaching ensemble genres in which they had fewer pedagogical experiences. Mary felt unsure about her abilities to teach in a band setting as a preservice strings teacher: "My experiences teaching band instrumental groups and ensembles made me feel incompetent...like I was not able to help those students" (questionnaire). Austin expressed apprehension for teaching in a high school jazz setting:

This week's teaching assignment for me...was working with their jazz band. Of all areas and grade levels I have worked with so far, jazz is my least confident area. I have not performed in any jazz band in college, so I am the most unsure of what I am doing in this setting. (e-journal) 
Changes to the teaching setting influenced participants' emotional response to teaching. Among the physiological state codes assigned to the pre-student teaching participant responses, 11 of $22(50 \%)$ had a negative connotation, such as physical tension or stress toward the new environment. However, after having successful prestudent teaching episodes, participants also expressed that their confidence was improving. These mixed emotional responses to teaching during pre-student teaching changed to mostly positive physiological states during student teaching. Steve described in his e-journal the impact that successful mastery experiences had on his confidence: "I got the opportunity to work with a quality high school jazz band, and the rehearsal went fairly well. A lot of nerves that I used to encounter from standing in front of strangers are starting to subside as I gain more experience.” Findings from participants' e-journal responses further supported this sentiment, indicating a slightly greater amount of positive emotions (e.g., increased confidence, excitement, encouraged) for teaching during student teaching than pre-student teaching (see Table 5). 
Table 5

Frequency and Sum of Efficacious Experiences Across Time

\begin{tabular}{|c|c|c|c|c|}
\hline \multirow[b]{2}{*}{ Source } & \multicolumn{2}{|c|}{ Pre-student teaching } & \multicolumn{2}{|c|}{ Student teaching } \\
\hline & $n$ & Sum & $n$ & Sum \\
\hline Physiological State & & 22 & & 12 \\
\hline Stress/Anxiety & 3 & 5 & 1 & 1 \\
\hline Hesitant & 1 & 2 & 0 & 0 \\
\hline Physical Tension & 1 & 1 & 0 & 0 \\
\hline Decreased Confidence & 2 & 3 & 3 & 4 \\
\hline Increased Confidence & 3 & 10 & 3 & 3 \\
\hline Excitement & 1 & 1 & 1 & 1 \\
\hline Comfortable & 0 & 0 & 2 & 2 \\
\hline Encouraged & 0 & 0 & 1 & 1 \\
\hline Mastery Experience & & 12 & & 12 \\
\hline Field unsuccessful & 2 & 2 & 2 & 4 \\
\hline Field successful & 4 & 7 & 4 & 8 \\
\hline Professional unsuccessful & 1 & 1 & 0 & 0 \\
\hline Professional successful & 1 & 2 & 0 & 0 \\
\hline Vicarious Experience & & 5 & & 3 \\
\hline Peer field observation & 1 & 1 & 0 & 0 \\
\hline Professional observation & 2 & 2 & 0 & 0 \\
\hline Studying & 2 & 2 & 1 & 2 \\
\hline Mentor observation & 0 & 0 & 1 & 1 \\
\hline Verbal Persuasion & & $\mathbf{0}$ & & 2 \\
\hline Positive student & 0 & 0 & 1 & 1 \\
\hline Positive mentor & 0 & 0 & 1 & 1 \\
\hline
\end{tabular}

Note. Data reflects codes from participants' 10 weekly reflections. Each data collection period was five weeks. Numbers in the $n$ column indicate the number of participants out of four that identified the code. Numbers in the Sum column indicate the number of times the code was identified among the participants.

The student teaching environment provided a sense of stability and consistency that affected participants' teaching self-efficacy and concerns positively, likely because they were in the classroom full time, and had a one-on-one mentor experience with their cooperating teacher. Participants reported initial feelings of nerves and less confidence at the start of student teaching, possibly due to three out of the four participants' being in elementary general music student teaching placements and not instrumental placements. However, over time, the student teachers gained efficacious mastery experiences and 
feedback from their cooperating teachers that influenced their self-efficacy and focused their concerns on students' learning, a finding that is consistent with previous research involving general education teachers (Boz \& Boz, 2010; Pyper, 2014). Supporting preservice teachers as they refine pedagogical approaches can be important to their efficacious and emotional development because they often lack influential teaching experiences that inform their self-efficacy (Bandura, 1997; Usher \& Pajares, 2006; Woolfolk Hoy \& Burke-Spero, 2005). Having discussions with preservice teachers early in their student teaching placement about prior successful pedagogical strategies that positively impacted students' performance ability or behavior may alleviate feelings of ineffectiveness or imposter phenomenon (Sims \& Cassidy, 2018). Reducing any negative feelings for teaching may result in a stronger influence on beliefs from verbal feedback and a more positive physiological state.

\section{Theme Three: Changing and Clustered Concerns}

Trends emerged among findings of participants' teaching concerns. Rehearsing, classroom management, adapting, and student learning were codes that contributed to the changing and clustered concerns theme.

The percentage and frequency of self concerns increased from pre-student teaching to student teaching $(n=8,21.05 \% ; n=11,27.50 \%)$. Similar results were found among student-impact concerns $(n=3,7.89 \% ; n=10,25.00 \%)$, whereas the percentage and frequency of task concerns decreased from pre-student teaching to student teaching ( $n=27,71.05 \% ; n=19,47.50 \%)$. However, most of the concerns reported by the participants during the pre-student teaching $(71.05 \%)$ and student teaching $(47.50 \%)$ periods were coded in the task category. Fewer concerns were identified as self or student 
for each collection period. (See Table 6 for the sums, means, and percentages of concerns coding.) Additional analyses indicated that a number of student-impact concern categories were coded during student teaching but not during pre-student teaching $(n=3)$ such as differentiated individuals and differentiated groups, and several task concern categories were coded during pre-student teaching but not student teaching $(n=6)$ including task knowledge, repertoire, and group size. See Table 7 for the frequency and sum of concern categories.

Table 6

Sums, Means, and Percentages of Concerns Codes by Metacategory Across Time

\begin{tabular}{lcccccc}
\hline & \multicolumn{3}{c}{ Pre-student teaching } & \multicolumn{3}{c}{ Student teaching } \\
\cline { 2 - 7 } Concern & Sum & $M$ & $\%$ & Sum & $M$ & $\%$ \\
\hline Task & 27 & 6.75 & 71.05 & 19 & 4.75 & 47.50 \\
Self & 8 & 2.00 & 21.05 & 11 & 2.75 & 27.50 \\
Student & 3 & 0.75 & 7.89 & 10 & 2.50 & 25.00 \\
\hline
\end{tabular}

Note. Data reflects codes from four participants' 10 weekly reflections. Each data collection period was five weeks.

The trajectory of preservice teacher concerns in the current study is similar to those of previous investigations (Berg \& Miksza, 2010; Killian, Dye, \& Wayman, 2013; Miksza \& Berg, 2013; Pigge \& Marso, 1989) and underscores Fuller and Bown's (1975) teachers' concerns theory. Preservice teachers may not be able to focus on student impact and pedagogical strategies until matters of personal identity are addressed, such as the ability to adapt to the setting or establishing rapport with students (Kagan, 1992; Miksza \& Berg, 2013). Although the findings of the present study may adhere to the developmental stages of teachers' concerns, the rate at which preservice teachers shift their focus is still unknown and may be influenced by their level of efficacy for teaching. 
Perhaps preservice teachers accomplish self-survival and teaching tasks that improves self-efficacy, before new concerns arise that more directly impact students' learning.

Table 7

Frequency and Sum of Concerns Categories Across Time

\begin{tabular}{llcccc}
\hline & & \multicolumn{2}{c}{ Pre-student teaching } & \multicolumn{2}{c}{ Student teaching } \\
\cline { 2 - 5 } Concern & Definition & $n$ & Sum & $n$ & Sum \\
\hline TTot & Task total & 3 & 27 & 0 & $\mathbf{1 9}$ \\
TK & Task knowledge & 3 & 0 & 0 \\
TIS & Instrument specific pedagogy & 2 & 3 & 0 & 0 \\
TRep & Repertoire & 2 & 2 & 0 & 0 \\
TGr & Group size & 1 & 4 & 0 & 2 \\
TT & Time & 1 & 1 & 2 & 4 \\
TReh & Rehearsing & 2 & 3 & 2 & 0 \\
TCond & Conducting & 1 & 2 & 0 & 5 \\
TCM & Classroom management & 2 & 3 & 3 & 0 \\
TPC & Pacing & 1 & 1 & 0 & 0 \\
TED & Error detection & 1 & 1 & 0 & 5 \\
TPL & Planning & 1 & 1 & 4 & 1 \\
TAB & Ability level & 2 & 3 & 1 & 0 \\
TCL & Clarity of instruction & 1 & 1 & 0 & 2 \\
TInt & Intensity of instruction & 0 & 0 & 2 & $\mathbf{1 1}$ \\
SeTot & Self total & & $\mathbf{8}$ & & 2 \\
Se & General self concern & 0 & 0 & 2 & 2 \\
SeR & Rapport & 0 & 0 & 1 & 0 \\
SeO & Organization & 1 & 1 & 0 & 0 \\
SeInd & Indecision & 1 & 1 & 0 & 1 \\
SePers & Personality & 0 & 0 & 1 & 3 \\
SeA & Adapting & 3 & 3 & 2 & 2 \\
SeAu & Authority & 1 & 2 & 1 & 0 \\
SePr & Peer/Colleague interaction & 1 & 1 & 0 & 2 \\
STot & Student total & & $\mathbf{3}$ & & $\mathbf{1 0}$ \\
SM & Student motivation & 1 & 1 & 1 & 2 \\
SL & Learning concern & 1 & 2 & 3 & 4 \\
SDi & Differentiated individuals & 0 & 0 & 1 & 1 \\
SDg & Differentiated group & 0 & 0 & 1 & 1 \\
SEnj & Enjoying the music & 0 & 0 & 2 & 2 \\
\hline Not D & rectsco & 1 & 1 & \\
\hline
\end{tabular}

Note. Data reflects codes from four participants' 10 weekly reflections. Each data collection period was five weeks. Numbers in the $n$ column indicate the number of participants out of four that identified the code. Numbers in the Sum column indicate the number of times the code was identified among the participants. $\mathrm{T}=$ Task concern. $\mathrm{Se}=$ Self concern. $\mathrm{S}=$ Student concern. 
Although participants' concerns seemed to change over time, there were consistent categories of concerns, or clusters, that participants discussed. For example, Colton reported numerous times about having concerns with the size of the ensemble, causing his level of anxiety to rise (e-journal). Mary expressed concern for her community ensemble students possibly falling behind other children that she did not teach (e-journal). She began to question her instrument-specific pedagogy, which led to feelings of stress. The preservice teachers in this study also consistently reported concerns for their ability to adapt to new teaching situations and rehearsing/teaching. Table 7 contains information about participants' specific categories of concerns.

Participants' ability to control classroom behavior was a consistent theme throughout pre-student teaching and student teaching. During field experiences, Colton and Steve expressed worry about the effect that teaching in an unfamiliar setting might have on their ability to control students' behavior, in particular the number of students in the pre-student teaching field placement. As time passed, the participants continued to focus on students' behaviors during their student teaching placements. Mary's ability to control students' behavior was an area of focus immediately during her student teaching experience. She said:

My teacher has given me a lot of advice, because she recognized that problem pretty quick. She's asked me to...catch their attention as soon as class starts and give them a task to work on or else they'll do their own thing...I have to wait for them. I'm used to just starting up as soon as it gets quiet enough for me to kind of talk over them. But she's telling me to wait until I get everyone's attention. (interview) 
Austin acknowledged that taking on more responsibility during student teaching meant becoming more invested by planning more diligently for managing students' behavior: "As I am continuing to take over more and more from my cooperating teacher this week, I know I will have to work even harder than usual in order to maintain attention, classroom behavior, participation, and even respect" (e-journal). Participants were able to express the efficacious improvement they felt as they became more successful at controlling student behavior during student teaching.

Participants' tendency to identify the same concerns week-to-week (i.e., clustered concerns) is consistent with results of previous research studies (Berg \& Miksza, 2010; McLaughlin, 1994; Powell, 2014, 2016). Miksza and Berg (2013) similarly reported that preservice music teachers had clustered concerns for classroom management and rehearsing/teaching strategies, in their study of preservice teachers' development over a 1.5-year period. Limited understanding of classroom procedures and students' learning needs may hinder preservice teachers' ability to focus on students' learning growth (Kagan, 1992), although teachers may always identify some concerns within each category (Miksza \& Berg, 2013). In addition to addressing Fuller and Bown's (1975) concerns stages, perhaps focus could be placed on reducing the number of teachers' concerns by improving their self-efficacy (Ghaith \& Shaaban, 1999). Addressing preservice teachers' pedagogical approaches, including classroom management, pacing, and accurate feedback (Madsen \& Geringer, 1989), could improve their efficacious beliefs. 


\section{Conclusion}

The first research question was designed to investigate the relationships between preservice teachers' self-efficacy and teaching concerns. The efficacious beliefs of participants were associated with their teaching concerns and were impacted by the contextual nature of field placements. Although researchers have found similar relationships to exist between self-efficacy and teachers' concerns (Boz \& Boz, 2010; Evans \& Tribble, 1986), few have explored the influence familiarity has on these beliefs. Improved familiarity in a setting brought about more positive efficacious beliefs and the identification of concerns that more directly impacted student learning. Powell (2016) suggested Fuller and Bown's (1975) concerns model could "serve as a structure for guiding reflective practice and assisting preservice teachers to attend to all aspects of their teaching, including student impact” (p. 501). Doing so may enhance preservice teachers' pedagogical focus on students' needs and self-efficacy for teaching strategies.

My second research question was developed to examine the extent that participants' concerns changed from pre-student teaching to student teaching. Results indicated that participants began to shift their concerns from self-survival and tasks to issues of student-impact during their student teaching experiences. During both time periods, task concerns were the most cited category by participants, with classroom management being the most discussed topic. This is not surprising because classroom management is often a topic of student teaching seminars and has been cited as an important skill among student teachers and university supervisors (Baumgartner, 2014; Baumgartner \& Councill, 2017; Campbell \& Thompson, 2007). Although taking some time to familiarize oneself in a new teaching setting is to be expected, cooperating 
teachers may be able to expedite their mentees' development by addressing the student teachers' concerns for classroom management early and often. Even if student teachers are not yet leading classes at the beginning of their placement, they can still perform activities such as taking student attendance as a way to assist their learning of student names and building rapport. Effectively addressing student behavior may also improve preservice teachers' self-efficacy for teaching strategies, thus influencing their preparation and motivation for future lessons (Ross, 1998).

In answering my third research question, (What pre-student teaching experiences do participants most commonly believe inform their self-efficacy for teaching?), I identified that the participants' teaching self-efficacy improved as a result of professional teaching experiences such as giving private lessons or working with high school marching bands. Similar to student teaching placements, participants appreciated the authenticity in these teaching settings. Observing model teachers and receiving pedagogical feedback from on-site directors further informed preservice teachers' efficacious beliefs. Music teacher educators can guide their students in finding authentic teaching experiences outside of the music education curriculum that matches students' pedagogical needs. Opportunities could include working at summer music camps, small group or private lessons, small ensembles at area schools, and community music programs. Further investigation into the impact that professional teaching experiences have on preservice teachers' self-efficacy and identity is warranted.

The small number of participants and the brief amount of time for data collection are limitations of the current study. Therefore, results cannot be generalized to all preservice teacher experiences. Longer time to examine participants' concerns and 
efficacious experiences would provide even more information from which to make recommendations and further our understanding of teacher development. However, the results of this study may be used to inform future investigations into the contextual nature of preservice instrumental teachers' efficacious beliefs.

Researchers might explore relationships between quantitative measures of preservice teachers' self-efficacy and their concerns. To what extent do prior teaching experiences in a music setting impact self-efficacy? Highly efficacious preservice teachers may have more confidence in their ability to meet individual students' needs than their counterparts, thereby having fewer concerns for their teaching preparation, strategies, and rapport with students (Ghaith \& Shaaban, 1999). Investigating how music teachers of different genders, races, or musical backgrounds identify shared efficacious experiences might also be of interest (Hendricks, 2014; Zeldin, Britner, \& Pajares, 2008). Further examination into the non-curricular teaching experiences that shape preservice teachers' beliefs may help music teacher educators make recommendations for experiences that can improve their students' self-efficacy. Results from these studies could further our understanding of self-efficacy characteristic of different groups of people, and how they interpret pedagogical experiences.

Preservice instrumental teachers' self-efficacy and teaching concerns were related to the contextual nature of each teaching setting. The themes of professional teaching experiences, familiarity, and changing and contextual concerns are consistent with prior research, but this study made a contribution to the literature by examining the influence these factors had on efficacious beliefs. Understanding the experiences that most impact preservice teachers' self-efficacy and teacher concerns can inform music teacher 
educators' curricular development and identification of experiences that improve selfefficacy. Music teacher educators may use the results of the current study to consider how transitions between field experiences influence their students' efficacious beliefs and emotions. I hope that consideration of the issues addressed in this research may help those involved in music teacher preparation to consider ways to provide the most effective support possible for their preservice teachers' development. 


\section{Chapter Five}

\section{Summary and Conclusions}

Self-efficacy has been defined as one's belief in the ability to perform a given task (Bandura, 1997). Within the larger framework of social cognitive theory, self-efficacy is theorized to moderate the relationship between an individual's behavior and cognition. Efficacious beliefs are context-specific, rather than a global trait. For example, an individual's self-efficacy to sing a traditional folk tune may be different than one's efficacy to sing a Mozart aria. Beliefs are influenced by four sources of information: enactive mastery experiences (successful and unsuccessful task experiences), vicarious experiences (observations of others), verbal persuasions (feedback from others), and physiological state (emotions and physical health specific to a task). Self-efficacy has the potential to influence an individual's motivation, self-regulation, decisions, and eventual success or failure (Usher \& Pajares, 2008).

The efficacious beliefs of teachers can impact their abilities and students' academic and musical achievement. General education teachers' self-efficacy is believed to influence their own teaching dispositions and behaviors, and students' success in the classroom (Woolfolk Hoy \& Davis, 2006). Efficacious beliefs have been studied among teachers in general education (Allinder, 1994; Coladarci, 1992; Gibson \& Dembo, 1984; Muijs \& Reynolds, 2001; Tschannen-Moran \& Woolfolk Hoy, 2001), K-12 music (Hancock, 2008; Wagoner, 2011), beginning music (Koerner, 2017), instrumental and vocal music (Biasutti \& Concina, 2018), and high school band settings (Regier, 2018). However, the authors of these studies did not explore how efficacious sources may 
influence instrumental teachers' beliefs or the potential pedagogical outcomes associated with them.

\section{Research Questions and Method}

The purpose of this dissertation was to better understand the sources of preservice and in-service instrumental music teachers' self-efficacy. A primary research question guided my study: To what extent do mastery experiences, verbal persuasions, vicarious experiences, and physiological state contribute to instrumental music teachers' selfefficacy? I also wanted to examine how self-efficacy beliefs were related to teachers' self-perceptions of their own pedagogical behaviors. In order to answer my primary questions, I completed a comprehensive literature review (Chapter 2), a survey of high school band directors (Chapter 3), and a qualitative study involving preservice instrumental music teachers (Chapter 4). The following sections highlight the major findings of these individual investigations.

\section{Major Findings}

\section{Literature Review}

Among the four sources of self-efficacy (i.e., mastery experience, vicarious experience, verbal persuasions, and physiological state), the relative success of previous teaching experiences has the most profound effect on beliefs (Bandura, 1997; Klassen \& Chiu, 2010). As teachers accumulate pedagogical experiences, they begin to receive feedback about their abilities to teach from respected individuals, which can impact their emotional responses to professional tasks (Tschannen-Moran, Woolfolk Hoy, \& Hoy, 2006). Woolfolk Hoy and Davis (2006) suggested that teachers' self-efficacy is impacted by their students' academic performance and behavior. From students' outcomes, 
teachers can evaluate their pedagogical approaches and make decisions about future teaching strategies. Given the importance of successful early pedagogical experiences on teachers' self-efficacy (Tschannen-Moran \& Woolfolk Hoy, 2007), I identified and discussed effective teaching skills that could promote student success in the rehearsal hall, including frequent and deliberate eye contact, providing clear, concise, and accurate feedback, varying a teachers' proximity to the ensemble, and setting proximal goals for students to attain.

Self-efficacy has been studied among preservice (Bergee, 2002; Prichard, 2017) and in-service music teachers (Biasutti \& Concina, 2018; Hancock, 2008; Koerner, 2017; Quesada, 1992; Regier, 2018; Wagoner, 2011), but few researchers have investigated the impact that the sources of self-efficacy have on instrumental directors' self-efficacy. The contextual nature of self-efficacy warrants investigation into the experiences that influence instrumental teachers' beliefs and the potential relationships it has with their pedagogical behaviors and dispositions. I concluded that researchers should investigate the extent that various sources influence instrumental teachers' self-efficacy over time and how beliefs may impact their teaching strategies. If instrumental teachers have high self-efficacy for teaching, it may contribute to their professional commitment, preparation, and effectiveness, and impact their students' self-regulation, music appreciation, and performance achievement.

\section{Survey Study}

I investigated the extent to which high school band directors' self-efficacy was influenced by each source and the relationship their beliefs had on effective teaching strategies. Participants $(N=610)$ were high school concert band directors (that belonged 
to the National Association of Music Education). The participants responded to items that comprised four survey sections: (a) Concert Band Directors' Self-Efficacy for Teaching Strategies Scale (BDSETS), (b) Sources of Self-Efficacy for Concert Band Teaching Scale, (c) effective teaching skills, and (d) demographic items. Participants' responses to these scales generated a self-efficacy for teaching strategies score and a score for each of the sources of self-efficacy. I split the self-efficacy for teaching strategies scores at the median in order to make teaching skills comparisons between higher self-efficacy directors and lower self-efficacy directors. Furthermore, based on their reported number of years of concert band teaching experience, I assigned directors to either the early (1-7 years), mid- (8-23 years), or late ( 24 or more years) career group to allow for comparisons between their self-efficacy, its sources, and their career stages.

Results of a multivariate regression analysis indicated mastery experience to have the most influence on concert band directors' self-efficacy, followed by verbal persuasions, physiological state, and vicarious experience, respectively. Further investigation into the impact of experience on beliefs indicated that concert band directors with at least 24 years of experience had the highest self-efficacy for teaching strategies, followed by mid- and early career directors. Mastery experience and verbal persuasions were predictive of directors at all career stages, and physiological state had an impact on mid-career directors' beliefs only. Vicarious experiences did not significantly predict directors' self-efficacy. These results indicated that teachers' selfefficacy was most influenced by their years of experience and the feedback they received from respected individuals about their concert band teaching abilities. As early career directors continue to teach and gain pedagogical experiences and feedback from mentors, 
their physiological state begins to strengthen. Toward the end of their careers, the effects of motivation and enthusiasm for teaching concert band on self-efficacy may decrease, and is replaced by other influences including years of teaching experience and support from respected individuals.

Survey results also indicated that directors with higher self-efficacy for teaching strategies scored themselves higher on effective teaching skills than did peers with lower self-efficacy. Skills and behaviors that have been found to relate to teacher intensity in previous studies were especially different between groups, including "presenting a lesson with clarity," "maintaining classroom management," and "maintaining an effective rehearsal pace" (Madsen \& Geringer, 1989). The results of my investigation indicated that directors with high self-efficacy for teaching in a concert band setting felt confident in their ability to develop students' performance ability while motivating and controlling student behavior. These findings are similar to those in Chapter 4 that indicated preservice teachers felt more efficacious for teaching after changing students' behavior using effective classroom management strategies.

\section{Qualitative Study}

In order to examine the contextual nature of efficacious beliefs and concerns, I examined the experiences and beliefs of four preservice instrumental teachers. I collected data for this case study through an open-response questionnaire about participants' efficacious teaching experiences, ten weekly e-journal reflections written during prestudent teaching $(n=5)$ and student teaching placements $(n=5)$, interviews, and my own researcher journal. Trustworthiness for the results was demonstrated by confirming data 
interpretation with a secondary coder, triangulating the results, clarifying researcher bias, and using member checks (Huberman \& Miles, 1994).

Mastery teaching experiences in familiar settings most impacted preservice teachers' self-efficacy and concerns. Changes to the age group or ensemble type might expose students to a broader array of ensembles, but the limited time in each setting made it difficult for participants to adjust their teaching for students' needs or know how to plan for their next instructional opportunity. As a result, participants' stress and low confidence led to negative emotions and influenced efficacious beliefs. Transferring from pre-student teaching to student teaching placements brought about appreciated consistency among participants as evidenced in their improving self-efficacy and physiological state. Preservice teachers reported a higher percentage of positive emotions and noted that they could focus on students' behavior and learning more than they had during their pre-student teaching experiences.

Teaching experiences outside of the university curriculum (i.e., professional experiences) such as giving private lessons or teaching a high school marching band were impactful on participants' efficacious teaching beliefs. Participants recognized changes in their capacity to improve students' performance ability due to the frequency and length of time with a group of students. Being in a consistent teaching setting allowed participants multiple opportunities to reflect on prior teaching achievements and adjust teaching strategies to meet the learning needs of students. In addition to pedagogical experiences, participants felt more confident in their teaching abilities after observing model instructors and receiving feedback about their instruction at professional teaching sites. 
Results indicated that participants made more comments about student-impact and self-survival concerns during student teaching than pre-student teaching placements. The increase in self concerns is likely due to the setting change from pre-student teaching to student teaching placements, whereas the consistency of placement across time may have increased student-impact concerns. Further investigation revealed that participants consistently expressed concerns for classroom management and rehearsing/teaching during both teaching placements. Considering that preservice teachers may always have some concerns in each category, finding ways to expedite the developmental process could reduce the amount of time that preservice teachers focus on early contextual factors such as rapport or confidence and instead identify ways to improve students' performance and academic abilities.

\section{Discussion}

The investigations in this dissertation were conducted to better understand the sources of instrumental music teachers' self-efficacy. Concert band directors' selfefficacy for teaching strategies were most influenced by mastery experiences, followed by verbal feedback, physiological state, and vicarious experiences (Chapter 3). Preservice teachers discussed similar source influences on their self-efficacy, most notably the positive impact that authentic teaching experiences (i.e., mastery experiences) had on their confidence for teaching instrumental music (Chapter 4). Results of previous studies in general education (Tschannen-Moran \& Johnson, 2011; Tschannen-Moran et al., 1998; Woolfolk Hoy \& Burke-Spero, 2005) have indicated similar source influences on teachers' efficacious beliefs. Successful teaching experiences can improve the feedback received from administrators, parents, and mentors, resulting in a stronger physiological 
state for teaching and improved student performance ability (Tschannen-Moran \& McMaster, 2009; Woolfolk Hoy \& Davis, 2006). A stronger sense of efficacy for teaching can also impact instrumental teachers' professional commitment and identity (Wagoner, 2011) and lower the risk of attrition and migration (Hancock, 2008). Examining ways instrumental teachers' self-efficacy affects their motivation and job satisfaction could provide support for cultivating teachers' efficacious beliefs.

Participants' self-efficacy was most associated with their amount of prior teaching experience, a result that is consistent with findings from studies of music teachers (Biasutti \& Concina, 2018; Wagoner, 2011). Novice teachers' beliefs may be especially impacted by successful teaching episodes due to a lack of influential teaching experiences (Woolfolk Hoy \& Burke-Spero, 2005); therefore, teachers may need support and a growth mindset to account for varying levels of success in the early stages of their development. As teachers gain pedagogical experiences, their self-efficacy becomes more resilient to change (Bandura, 1997). However, the relative influence that sources had on teachers' beliefs differed across time, most notably their physiological state. The impact that teachers' emotional state had on their self-efficacy was significant among mid-career directors (8-23 years) but not early (1-6) or late career directors (24 or more). Researchers who have studied teachers' career stages have suggested that the motivation and enthusiasm that late career teachers once had is replaced with feelings of satisfaction and serenity (Day \& Gu, 2007; Huberman, 1989). Longitudinal research on instrumental teachers' self-efficacy and its sources would help our understanding of their development, most notably clarifying the impact that physiological state has on teachers 
at different stages of their careers. Qualitative investigations of teachers' dispositions and emotions at different career stages would be informative.

Results indicated a relationship between instrumental teachers' self-reported use of effective teaching skills and their self-efficacy. Researchers have identified skills associated with classroom behavior as being important to the success of a teacher (Miksza, Roeder, \& Biggs, 2010; Teachout, 1997). In their responses to the current study, highly efficacious instrumental teachers reported greater effectiveness with controlling student behavior than did lower efficacy teachers. Participants' efficacy also related with pedagogical abilities contributing to teacher intensity, including "presenting a lesson with clarity," "maintaining an effective rehearsal pace," and "maintaining classroom management and procedures" (Madsen \& Geringer, 1989). Consistent with previous findings (Miksza \& Berg, 2013), preservice instrumental teachers' ability to focus on pedagogical behaviors that improve students' learning was impacted by their familiarity with a setting. Years of experience may also be an important factor in changing teachers' focus from self-survival to their students' learning (Pigge \& Marso, 1989). Additional relationships have been reported between the number of teachers' concerns and their selfefficacy (Ghaith \& Shaaban, 1999). Investigating relationships among effective teaching behaviors, teaching concerns, and self-efficacy would provide information about the preparation and perceived pedagogical effectiveness of teachers with varying levels of efficacious beliefs.

\section{Suggestions for Educators}

Previous task attainments had the most impact on participants' teaching selfefficacy. Instrumental teachers can improve their self-efficacy by refining their 
pedagogical strategies in authentic teaching environments that offer multiple opportunities to improve their planning and strategies. For example, preservice teachers appreciated professional and student teaching experiences that allowed enough time to build rapport with students and adjust instruction to meet learners' needs (Chapter 4). Familiarity and experience in a setting appears to influence beliefs as evidenced by selfefficacy for teaching strategies relating with years of concert band teaching experience among in-service concert band directors (Chapter 3). Teachers who identify as having low self-efficacy for teaching strategies can use self-analysis or feedback from administrators and students to identify skills that need improvement, such as pacing, specific feedback, or eye contact. Improved pedagogical approaches that raise students' performance achievement can bolster instrumental teachers' beliefs in their ability to affect change in students' effort and behavior.

Emotional and pedagogical support for preservice and novice instrumental teachers can positively impact their self-efficacy as they develop resilient beliefs through influential teaching experiences. In states or districts where music-specific mentors are not provided to novice teachers, school district administrators can provide mentors that are considerate of their mentee's pedagogical, psychological, and contextual needs (Koerner, 2018). For music educators needing music-specific feedback and support, video conferencing has become an effective option for mentorship (Bautista, Wong, \& Cabedo-Mas, 2018). Findings from Chapter 3 indicated that participants' self-efficacy for teaching strategies related to their physiological state for teaching, particularly among teachers with the most number of years in the profession. Although results from Chapter 4 indicated that preservice teachers can have less confidence towards teaching due to 
contextual changes, their physiological state across time seemed to become more positive as they identified more successful teaching episodes and student improvement. Music teacher educators could discuss Fuller and Bown's (1975) concerns model with instrumental teachers as a way to alleviate issues of confidence or stress so that matters of teaching strategy and student learning can more readily be addressed. Meditation practices (Diaz, 2018) and discussion of imposter phenomena (Sims \& Cassidy, 2018) could resolve further negative physiological influences on teachers' beliefs.

Results indicated that vicarious experiences had little impact on participants' selfefficacy. To improve the influence of vicarious experiences on teachers' self-efficacy, developmental experiences should include opportunities to implement new teaching strategies with feedback and support after an observation. Instrumental teachers could study effective pedagogical strategies used by peers in the rehearsal setting and then invite expert teachers to provide feedback on strategy implementation in-person or through reviewing teaching videos. Specific to the student teacher or field placement, cooperating teachers should consider teaching a model lesson that mentees can replicate and receive feedback on early in the placement as they become familiar with the setting and their responsibilities. Successfully implementing strategies learned from respected teachers can inform instrumental teachers' confidence to transfer observed pedagogical skills to their own ensemble rehearsals.

\section{Conclusion}

I designed this dissertation to better understand the sources of preservice and inservice instrumental music teachers' self-efficacy. Based on the data collected, mastery experiences had the most influence on efficacious beliefs. Participants' verbal support 
from respected individuals and physiological state towards specified teaching tasks also impacted their self-efficacy. Results indicated that teachers' self-efficacy was related to experience and that the influence of each source can change with career stages. The experiences that impact teachers' physiological state may be of particular interest to other researchers, as this source significantly predicted mid-career directors' self-efficacy but not the beliefs of early or late career directors. Future research designed to examine the sources of preservice instrumental teachers' beliefs is also needed, as the influence of each source may change depending on preservice teachers' prior pedagogical experiences and curricular requirements. The findings of this study indicated a strong relationship between teachers' self-efficacy for teaching strategies and effective teaching behaviors. Teachers with high efficacy also appear to have more concern for student learning and less on their own self needs. Further investigations into the relationships associated with instrumental teachers' self-efficacy could indicate a need to develop teachers' beliefs as a means to improve their students' motivation, self-regulation, self-efficacy, and performance achievement, an outcome that could positively shape the administrative, community, and parental support provided to instrumental programs. 


\section{References}

Allinder, R. (1994). The relationship between efficacy and the instructional practices of special education teachers and consultants. Teacher Education and Special Education, 17, 86-95. doi:10.1177/088840649401700203

Anderson, R. N., Greene, M. L., \& Loewen, P. S. (1988). Relationships among teachers' and students' thinking skills, sense of efficacy, and student achievement. Alberta Journal of Educational Research, 34, 148-165. Retrieved from http://psycnet.apa.org/record/1989-13522-001

Anderson, S. L., \& Betz, N. E. (2001). Sources of social self-efficacy expectations: Their measurement and relation to career development. Journal of Vocational Behavior, 55, 98-117. doi:10.1006/jvbe.2000.1753

Ashton, P., \& Webb, R. (1986). Making a difference: Teachers' sense of efficacy and student achievement. New York, NY: Longman.

Austin, J. R., \& Miksza, P. J. (2012). Trying on teaching: Effects of a precollegiate music teacher recruitment program. Journal of Music Teacher Education, 21, 14-27. doi: $10.1177 / 1057083711401712$

Austin, J. R., \& Vispoel, W. P. (1998). How American adolescents interpret success and failure in classroom music: Relationships among attributional beliefs, self-concept and achievement. Psychology of Music, 26, 26-45.

doi:10.1177/0305735698261004

Bandura, A. (1978). Reflections on self-efficacy. Advances in Behavior Research and Therapy, 1, 237-269. doi:10.1016/0146-6402(78)90012-7 
Bandura, A. (1983). Self-efficacy determinants of anticipated fears and calamities. Journal of Personality and Social Psychology, 45, 464-469. doi:10.1037/0022-3514.45.2.464

Bandura, A. (1986). Social foundations of thought and action. Englewood Cliffs, NJ: Prentice Hall.

Bandura, A. (1997). Self-efficacy: The exercise of control. New York, NY: W. H. Freeman and Company.

Bandura, A. (2006). Guide for constructing self-efficacy scales. In F. Pajares \& T. Urdan, (Eds.), Self-efficacy beliefs of adolescents (pp. 307-337). Greenwich, CT: Information Age.

Bandura, A., \& Jourden, F. J. (1991). Self-regulatory mechanisms governing the impact of social comparison on complex decision making. Journal of Personality and Social Psychology, 60, 941-951. doi:10.1037/0022-3514.60.6.941

Bandura, A., \& Schunk, D. H. (1981). Cultivating competence, self-efficacy, and intrinsic interest through proximal self-motivation. Journal of Personality and Social Psychology, 41, 586-598. doi:10.1037/0022-3514.41.3.586

Barnes, G. L. V. (1998). A comparison of self-efficacy and teaching effectiveness in preservice string teachers. Dissertation Abstracts International: Section A. Humanities and Social Sciences, 59(1), 3767. Retrieved from https://etd.ohiolink.edu/rws_etd/document/get/osu1250267731/inline

Bauer, W. I., \& Berg, M. H. (2001). Influences on instrumental music teaching. Bulletin of the Council for Research in Music Education, 150, 53-66. Retrieved from https://www.jstor.org/stable/40319099 
Baughman, M., \& Baumgartner, C. M. (2018). Preservice teachers' experiences teaching an adult community music ensemble. International Journal of Music Education, 36, 601-615. doi:10.1177/0255761418775128

Baumgartner, C. M. (2014). An examination of music student teaching seminars at Midwestern universities. Journal of Music Teacher Education, 24, 51-64. doi:10.1177/1057083713494013

Baumgartner, C. M., \& Councill, K. H. (2017). Music student teaching seminars: An examination of current practices across the United States. Update: Applications of Research in Music Education, 35, 62-69. doi:10.1177/8755123315615183

Bautista, A., Wong, J., \& Cabedo-Mas, A. (2018). Music teachers' perspectives on live and video-mediated peer observation as forms of professional development. Journal of Music Teacher Education. Advanced online publication. doi: $10.1177 / 1057083718819504$

Benson, M. A. (2008). Effective mentoring for new music teachers: An analysis of the mentoring programs for new music teachers as described in the literature. Update: Applications of Research in Music Education, 26, 42-49. doi: $10.1177 / 875512330837153$

Berg, M. H., \& Miksza, P. (2010). An investigation of preservice music teacher development and concerns. Journal of Music Teacher Education, 20, 39-55. doi: $10.1177 / 1057083710363237$

Bergee, M. J. (2002). Direct and mediated experiences: Effects on classroom management self-efficacy. Journal of Music Teacher Education, 12, 33-37. doi:10.1177/10570837020120010301 
Berman, P., McLaughlin, M. W., Bass, G., Pauly, E., \& Zellman, G. (1977).

Federal programs supporting educational change, Volume VII: Factors affecting implementation and continuation. Retrieved from Rand Corporation website: www.rand.org/pubs/reports/R1589z7.html

Betoret, F. D. (2006). Stressors, self-efficacy, coping resources, and burnout among secondary school teachers in Spain. Educational Psychology, 26, 519-539. doi:10.1080/01443410500342492

Biasutti, M., \& Concina, E. (2018). The effective music teacher: the influence of personal, social, and cognitive dimensions on music teacher selfefficacy. Musicae Scientiae, 22, 264-279. doi:10.1177/1029864916685929

Blackwell, J. A., \& Roseth, N. E. (2018). Problem-based learning in a woodwind methods course: An action research study. Journal of Music Teacher Education. 28, 55-69. doi:10.1177/1057083718769262.

Boz, Y., \& Boz, N. (2010). The nature of the relationship between teaching concerns and sense of efficacy. European Journal of Teacher Education, 33, 279-291. doi:10.1080/02619768.2010.490910

Britner, S. L., \& Pajares, F. (2006). Sources of science self-efficacy beliefs of middle school students. Journal for Research in Science Teaching, 43, 485-499. doi:10.1002/tea.20131

Broyles, J. (1997). Effects of videotape analysis on role development of student teachers in music (Doctoral dissertation). Dissertation Abstracts International, 58(03A), 823. 
Burley, W. W., Hall, B. W., Villeme, M. G., \& Brockmeier, L. L. (1991, April). A path analysis of the mediating role of efficacy in first-year teachers' experiences, reactions, and plans. Paper presented at the annual meeting of the American Educational Research Association, Chicago, IL.

Burn, K., Hagger, H., Mutton, T., \& Everton, T. (2000). Beyond concerns with self: The sophisticated thinking of beginning student teachers. Journal of Education for Teaching, 26, 259-278. doi:10.1080/713676889

Calderhead, J., \& Robson, M. (1991). Images of teaching: Student teachers' early conceptions of classroom practice. Teaching and Teacher Education, 7, 1-8. doi:10.1016/0742-51X(91)90053-R

Campbell, M. R., \& Thompson, L. K. (2007). Perceived concerns of preservice music education teachers: A cross-sectional study. Journal of Research in Music Education, 55, 162-176. doi:10.1177/002242940705500206

Carvalho, E. D. (1997). Choral students' attentiveness and attitude as related to conductors' score utilization and eye contact. Dissertation Abstracts International, 59, 2410A.

Cassidy, J. W. (1990). Effect of intensity training on preservice teachers' instruction accuracy and delivery effectiveness. Journal of Research in Music Education, 38, 164-174. doi: $10.2307 / 3345180$

Chacon, C. T. (2005). Teachers' perceived efficacy among English as a foreign language teachers in middle schools in Venezuela. Teaching and Teacher Education, 21, 257-272. doi:1016/j.tate.2005.01.001 
Ciorba, C. R. (2009). Predicting jazz improvisation achievement through the creation of a path-analytical model. Bulletin of the Council for Research in Music Education, 180, 43-57. Retrieved from http://www.jstor.org/stable/40319319

Clance, P. R. (1985). The impostor phenomenon: Overcoming the fear that haunts your success. Atlanta, GA: Peachtree.

Cohen, J. (1992). A power primer. Psychological Bulletin, 112(1), 155.

Coladarci, T. (1992). Teachers' sense of efficacy and commitment to teaching. Journal of Experimental Education, 60, 323-337. doi:10.1080/00220973.1992.9943869

Coleman, T. R. (1999). The music student teaching experience: Making connections. Dissertation Abstracts International, Section A: Humanities and Social Sciences, 61(02A), 540.

Conway, C. M. (2002). Perceptions of beginning teachers, their mentors, and administrators regarding preservice music teacher preparation. Journal of Research in Music Education, 50, 20-36. doi:10.2307/3345690

Conway, C. M. (2003). What is induction? In. C. M. Conway (Ed.), Great beginnings for music teachers: Mentoring and supporting new teachers (pp. 27-33). Reston, VA: MENC.

Conway, C. M. (2012). Ten years later: Teachers reflect on "perceptions of beginning teachers, their mentors, and administrator regarding preservice music teacher preparation". Journal of Research in Music Education, 60, 324-338.

doi:10.1177/0022429412453601 
Cousins, J. B., \& Walker, C. A. (2000). Predictors of educators' valuing of systemic inquiry in schools. Canadian Journal of Program Evaluation, Special Issue, 2553. Retrieved from http://evaluationcanada.ca/secure/15-0-025.pdf

Creswell, J. W. (2013). Qualitative inquiry \& research design: Choosing among five approaches (3rd ed.). Thousand Oaks, CA: Sage.

Czerniak, C., \& Schriver-Waldon, M. (1991, April). A study of science teaching efficacy using qualitative and quantitative research methods. Paper presented at the annual meeting of the National Association for Research in Science Teaching, Lake Geneva, WI.

Davison, P. D. (2010). The role of self-efficacy and modeling in improvisation among intermediate instrumental music students. Journal of Band Research, 45(2), 4258. Retrieved from http://proxy.mul.missouri.edu/login?url=http://search.ebscohost.com/login.aspx?d irect $=$ true $\& \mathrm{db}=$ asn $\& A N=49186182 \&$ site $=$ eds-live $\&$ scope $=$ site

Day, C., \& Gu, Q. (2007). Variations in the conditions for teachers' professional learning and development: Sustaining commitment and effectiveness over a career. Oxford Review of Education, 33, 423-443. doi:10.1080/03054980701450746

DeLorenzo, L. (1992). Perceived problems of beginning music teachers. Bulletin of the Council for Research in Music Education, 113, 9-25. Retrieved from https://www.jstor.org/stable/40318508

Denzin, N. K., \& Lincoln, Y. S. (2005). The Sage handbook of qualitative research (3rd ed.). Thousand Oaks, CA: Sage. 
Diaz, F. M. (2018). Relationships among meditation, perfectionism, mindfulness, and performance anxiety among collegiate music students. Journal of Research in Music Education, 66, 150-167. doi:10.1177/0022429418765447

Dolloff, L. A. (1996). Expertise in choral music education: Implications for teacher education. Dissertation Abstracts International, 56(07), 2600.

Duke, R. A., \& Henninger, J. C. (2002). Teachers' verbal corrections and observers' perceptions of teaching and learning. Journal of Research in Music Education, 50, 75-87. doi:10.2307/3345694

Duke, R. A., Prickett, C. A., \& Jellison, J. A. (1998). Empirical description of the pace of music instruction. Journal of Research in Music Education, 46, 265-280. doi: $10.2307 / 3345628$

Duke, R. A., \& Simmons, A. L. (2006). The nature of expertise: Narrative descriptions of 19 common elements observed in the lessons of three renowned artist-teachers. Bulletin for the Council of Research in Music Education, 170, 7-19. Retrieved from https://www.jstor.org/stable/40319345

Dutton, M. (1990). An investigation of the relationship between training in cooperative learning and teacher job satisfaction (Doctoral dissertation, Portland State University). doi:10.15760/etd.1141

Eccles, J. (1983). Expectancies, values, and academic behavior. In J. T. Spence (Ed.), Achievement and achievement motives: Psychological and sociological approaches (pp. 77-146). San Francisco, CA: W. H. Freeman. 
Evans, E. D., \& Tribble, M. (1986). Perceived teaching problems, self-efficacy, and commitment to teaching among preservice teachers. The Journal of Educational Research, 80, 81-85. doi:10.1080/00220671.1986.10885728

Faul, F., Erdfelder, E., Lang, A.G., \& Buchner, A. (2007). G*Power 3: A flexible statistical power analysis program for the social, behavioral, and biomedical sciences. Behavior Research Methods, 39, 175-191.

Fisher, R. A. (2014). The impacts of the voice change, grade level, and experience on the singing self-efficacy of emerging adolescent males. Journal of Research in Music Education, 62, 277-290. doi:10.1177/0022429414544748

Fuller, F. (1969). Concerns of teachers: A developmental conceptualization. American Educational Research Journal, 6, 207-226. doi:10.2307/1161894

Fuller, F., \& Bown, O. (1975). Becoming a teacher. In K. Ryan (Ed.), Teacher education, Part II: The 74th yearbook of the National Society for the Study of Education (pp. 25-52). Chicago, IL: University of Chicago Press.

Ghaith, G., \& Shaaban, K. (1999). The relationship between perceptions of teaching concerns, teacher efficacy, and selected teacher characteristics. Teaching and Teacher Education, 15, 487-496. doi:10.1016/S0742-051X(99)00009-8

Gibson, S., \& Dembo. M. (1984). Teacher efficacy: A construct validation. Journal of Educational Psychology, 76, 569-582. doi:10.1037/0022-0663.76.4.569

Glickman, C., \& Tamashiro, R. (1982). A comparison of first-year, fifth-year, and former teachers on efficacy, ego development, and problem solving. Psychology in Schools, 19, 558-562. doi:10.1002/1520-6807(198210)19:4<558::AID- PITS2310190426>3.0.CO;2-F 
Goolsby, T. W. (1996). Time use in instrumental rehearsals: A comparison of experienced, novice, and student teachers. Journal of Research in Music Education, 44, 286-303. doi:10.2307/3345442

Goolsby, T. W. (1997). Verbal instruction in instrumental rehearsals: A comparison of three career levels and preservice teachers. Journal of Research in Music Education, 45, 21-40. doi:10.2307/3345463

Guskey, T. R. (1989). Attitude and perceptual change in teachers. International Journal of Educational Research, 13, 439-453. doi:10.1016/0883-0355(89)90039-6

Hackett, G., \& Betz, N. E. (1989). An exploration of the mathematics self-efficacy mathematics performance correspondence. Journal for Research in Mathematics Education, 20, 261-273. doi:10.2307/749515

Hallam, S. (1998). The predictors of achievement and dropout in instrumental tuition. Psychology of Music, 26, 116-132. doi:10.1177/0305735698262002

Hamann, D. L. (1982). An assessment of anxiety in instrumental and vocal performances. Journal of Research in Music Education, 30, 77-90. doi:10.2307/3345040

Hancock, C. B. (2008). Music teachers at risk for attrition and migration: An analysis of the 1999-2000 schools and staffing survey. Journal of Research in Music Education, 56, 130-144. doi:10.1177/0022429408321635

Hanton, S., \& Jones, G. (1999). The effects of a multimodal intervention program on performers: II. Training the butterflies to fly in formation. The Sport Psychologist, 13(1), 22-41. doi:10.1123/tsp.13.1.22 
Haston, W., \& Russell, J. A. (2012). Turning into teachers: Influences of authentic context learning experiences on occupational identity development of preservice music teachers. Journal of Research in Music Education, 59, 369-392. doi:10.1177/0022429411414716

Hendricks, K. S. (2014). Changes in self-efficacy beliefs over time: Contextual influences of gender, rank-based placement, and social support in a competitive orchestra environment. Psychology of Music, 42, 347-365. doi: $10.1177 / 0305735612471238$

Hollandsworth, J. G., Glazeski, R. C., Kirkland, K., Jones, G. E., \& Van Norman, L. R. (1979). An analysis of the nature and effects of test anxiety: Cognitive, behavioral, and physiological components. Cognitive Therapy and Research, 3, 165-180. doi:10.1007/BF01172603

Hoy, W. K., \& Woolfolk, A. E. (1990). Socialization of student teachers. American Educational Research Journal, 27, 279-300. doi:10.3102/00028312027002279

Huberman, M. (1989). The professional life cycle of teachers. Teachers College Record, 91, 31-57. Retrieved from ERIC database. (EJ398425)

Huberman, A. M., \& Miles, M. B. (1994). Data management and analysis methods. In N. K. Denzin \& Y. S. Lincoln (Eds.), Handbook of qualitative research (pp. 428444). Thousand Oaks, CA: Sage.

Joyce, B., \& Showers, B. (1988). Student achievement through staff development. White Plains, NY: Longman. 
Kagan, D. M. (1992). Professional growth among preservice and beginning teachers. Review of Educational Research, 62, 129-169. doi:10.3102/00346543062002129

Kagan, D. M., \& Tippins, D. J. (1991). How teachers' classroom cases express their pedagogical beliefs. Journal of Teacher Education, 42, 281-291. doi:10.1177/002248719104200406

Killian, J. N., Dye, K. G., \& Wayman, J. B. (2013). Music student teachers: Pre-student teaching concerns and post-student teaching perceptions over a 5-year period. Journal of Research in Music Education, 61, 63-79. doi:10.1177/0022429412474314

Kitchel, L. (2017). A study of social comparisons and their effects on high school choir directors (Doctoral dissertation, University of Missouri-Columbia). doi:10.32469/10355/63669

Klassen, R. M. (2004). A cross-cultural investigation of the efficacy beliefs of South Asian immigrant and Anglo non-immigrant early adolescents. Journal of Educational Psychology, 96, 731-742. doi:10.1037/0022-0663.96.4.731

Klassen, R. M., \& Chiu, M. M. (2010). Effects on teachers' self-efficacy and job satisfaction: Teacher gender, years of experience, and job stress. Journal of Educational Psychology, 102, 741-756. doi:10.1037/a0019237

Klassen, R. M., \& Tze, V. M. (2014). Teachers' self-efficacy, personality, and teaching effectiveness: A meta-analysis. Educational Research Review, 12, 59-76. doi:10.1016/j.edurev.2014.06.001 
Koerner, B. D. (2017). Beginning music teacher mentoring: impact on reflective practice, teaching efficacy, and professional commitment (Doctoral dissertation). Retrieved from https://scholar.colorado.edu/mued_gradetds/9

Lent, R. W., Lopez, F. G., \& Bieschke, K. J. (1991). Mathematics self-efficacy: Sources and relation to science-based career choice. Journal of Counseling Psychology, 38, 424-430. doi:10.1037/0022-0167.38.4.424

Lincoln, Y. S., \& Guba, E. G. (1985). Naturalistic inquiry. Beverly Hills, CA: Sage.

Lopez, F. G., \& Lent, R. W. (1992). Sources of mathematics self-efficacy in high school students. Career Development Quarterly, 41, 3-9. doi:10.1002/j.2161-0045.1992.tb00350.x

L'Roy, D. (1983). The development of occupational identity in undergraduate music education majors (Unpublished doctoral dissertation). North Texas State University, Denton.

MacLeod, R. B., \& Walter, J. S. (2011). A descriptive study of cooperating teachers' perceptions regarding student teacher preparation. Bulletin of the Council for Research in Music Education, 190(Fall), 21-34.

doi:10.5406/bulcouresmusedu. 190.0021

Maddux, J. E. (1995). Self-efficacy theory: An introduction. In J. E. Maddux (Ed.), Selfefficacy, adaptation, and adjustment: Theory, research, and application (pp. 333). New York, NY: Plenum.

Madsen, C. K., \& Geringer, J. M. (1989). The relationship of teacher "on-task" to intensity and effective music teaching. Canadian Music Educator, 30, 87-94. 
Madsen, C. K., Standley, J. M., Byo, J. L., \& Cassidy, J. W. (1992). Assessment of effective teaching by instrumental music student teachers and experts. Update: Applications of Research in Music Education, 10, 20-24.

doi:10.1177/875512339201000206

Madsen, K. (2003). The effect of accuracy of instruction, teacher delivery, and student attentiveness on musicians' evaluation of teacher effectiveness. Journal of Research in Music Education, 51, 38-50. doi:10.2307/3345647

Marchant-Haycox, S. E., \& Wilson, G. D. (1992). Personality and stress in performing artists. Personality and Individual Differences, 13, 1061-1068.

doi:10.1016/0191-8869(92)90021-G

Marso, R. N., \& Pigge, F. L. (1989). The influence of preservice training and teaching experience upon attitude and concerns about teaching. Teaching and Teacher Education, 5, 33-41. doi:10.1016/0742-051X(89)90017-6

Martin, O. L. (1989). Does teacher efficacy beliefs begin with teacher education: Implications from student teacher candidates. Retrieved from ERIC database. (ED324273)

Matsui, T., Matsui, K., \& Ohnishi, R. (1990). Mechanisms underlying math self-efficacy learning of college students. Journal of Vocational Behavior, 37, 225-238. doi:10.1016/0001-8791(90)90042-Z

McCormick, J., \& McPherson, G. E. (2003). The role of self-efficacy in a musical performance examination: An exploratory structural equation analysis. Psychology of Music, 31, 37-51. doi:10.1177/0305735603031001322 
McLaughlin, H. J. (1991). The reflection on the blackboard: student teacher selfevaluation. Internation Journal of Qualitative Studies in Education, 4, 141159. doi:10.1080/0951839910040204

McPherson, G. E., \& McCormick, J. (2006). Self-efficacy and music performance. Psychology of Music, 34, 325-339. doi:10.1177/0305735606064841

Meiklejohn, J., Phillips, C., Freedman, M. L., Griffin, M. L., Biegel, G., Roach, A., ... \& Isberg, R. (2012). Integrating mindfulness training into K-12 education: Fostering the resilience of teachers and students. Mindfulness, 3, 291-307. doi:10.1007/s12671-012-0094-5

Merriam, S. B. (1998). Qualitative research and case study application in education. San Francisco, CA: Jossey-Bass.

Merton, R. K., Fiske, M., \& Kendall, P.L. (1990). The focused interviews: A manual of problems and procedures (2nd ed.). New York: Free Press.

Midgley, C., Feldlaufer, H., \& Eccles, J. S. (1989). Change in teacher efficacy and student self-and task-related beliefs in mathematics during the transition to junior high school. Journal of Educational Psychology, 81, 247-258.

doi:10.1037/0022-0663.81.2.247

Miksza, P., \& Austin, J. R. (2010). Eyes wide open: High school student reflections on music teaching experiences within a pre-collegiate recruitment program. Bulletin of the Council for Research in Music Education, 185, 7-20. Retrieved from https://www.jstor.org/stable/41110362 
Miksza, P., \& Berg, M. H. (2013). A longitudinal study of preservice music teacher development: Application and advancement of the Fuller and Bown teacherconcerns model. Journal of Research in Music Education, 61, 44-62.

doi:10.1177/0022429412473606

Miksza, P., Roeder, M., \& Biggs, D. (2010). Surveying Colorado band directors' opinions of skills and characteristics important to successful music teaching. Journal of Research in Music Education, 57, 364-381. doi: $10.1177 / 0022429409351655$

Miksza, P., \& Tan, L. (2015). Predicting collegiate wind players' practice efficiency, flow, and self-efficacy for self-regulation: An exploratory study of relationships between teachers' instruction and students' practicing. Journal of Research in Music Education, 63, 162-179. doi:10.1177/0022429415583474

Miles, M. B, \& Huberman, A. M. (1994). Qualitative data analysis: An expanded sourcebook. Thousand Oaks, CA: Sage.

Milner, H. R., \& Woolfolk Hoy, A. (2003). A case study of an African American teacher's self-efficacy, stereotype threat, and persistence. Teaching and Teacher Education, 19, 263-276. doi:10.1016/S0742-051X(02)00099-9

Moore, W., \& Esselman, M. (1992, April) Teacher efficacy, empowerment, and a focused instructional climate: Does student achievement benefit? Paper presented at the annual meeting of the American Educational Research Association, San Francisco, CA. 
Moriarty, B., Douglas, G., Punch, K., \& Hattie, J. (1995). The importance of self-efficacy as a mediating variable between learning environments and achievement. British Journal of Educational Psychology, 65, 73-84.

doi:10.1111/j.2044-8279.1995.tb01132.x

Morrison, S. J., Price, H. E., Geiger, C., \& Cornacchio, R. (2009). The effect of conductor expressivity on ensemble performance evaluation. Journal of Research in Music Education, 57, 37-49. doi:10.1177/0022429409332679

Muijs, D., \& Reynolds, D. (2002). Teachers' beliefs and behaviors: What really matters. Journal of Classroom Interaction, 37(2), 3-15. Retrieved by http://www.jstor.org/stable/23870407

Mulholland, J., \& Wallace, J. (2001). Teacher induction and elementary science teaching: enhancing self-efficacy. Teaching and Teacher Education, 17, 243-261. doi:10.1016/S0742-051X(00)00054-8

Murphy, S., \& Jowdy, D. (1992). Imagery and mental practice. In T.Horn (Ed.), Advances in sport psychology (pp. 221-250). Champaign, IL: Human Kinetic.

Napoles, J. (2006). The relationship between type of teacher talk and student attentiveness. Journal of Music Teacher Education, 16, 7-19. doi:10.1177/10570837060160010103

Napoles, J. (2007). The effect of duration of teacher talk on the attitude, attentiveness, and performance achievement of high school choral students. Research Perspectives in Music Education, 11, 22-29. 
Nielsen, S. G. (2004). Strategies and self-efficacy beliefs in instrumental and vocal individual practice: A study of students in higher music education. Psychology of Music, 32, 418-431. doi:10.1177/0305735604046099

Pajares, F. (2003). Self-efficacy belief, motivation, and achievement in writing: A review of the literature, Reading and Writing Quarterly, 19, 139-158. doi:10.1080/10573560390143085

Pajares, F. (2005). Gender differences in mathematics self-efficacy beliefs. In A. M. Gallagher \& J. C. Kauffman (Eds.), Gender differences in mathematics: An integrative psychological approach (pp. 294-315). New York, NY: Cambridge University Press.

Pajares, F. (2006). Self-efficacy during childhood and adolescence: Implications for teachers and parents. In F. Pajares \& T. Urdan, (Eds.), Self-efficacy beliefs of adolescents (pp. 339-367). Greenwich, CT: Information Age.

Palmer, D. H. (2006). Sources of self-efficacy in a science methods course for primary teacher education students. Research in Science Education, 36, 337-353. doi:10.1007/s11165-005-9007-0

Paul, S. J. (1998). The effects of peer teaching experiences on the professional teacher role development of undergraduate instrumental music education majors. Bulletin of the Council for Research in Music Education, 137, 73-92. Retrieved from https://www.jstor.org/stable/40318933 
Paul, S. J., Teachout, D. J., Sullivan, J. M., Kelly, S. N., Bauer, W. I., \& Raiber, M. A. (2001). Authentic-context learning activities in instrumental music teacher education. Journal of Research in Music Education, 49, 136-145. doi: $10.2307 / 3345865$

Pigge, F. L., \& Marso, R. N. (1989, March). A longitudinal assessment of the affective impact of preservice training on prospective teachers. Paper presented at the annual meeting of the American Educational Research Association, San Francisco, CA.

Pike, P. D. (2014). An exploration of the effect of cognitive and collaborative strategies on keyboard skills of music education students. Journal of Music Teacher Education, 23, 79-91. doi:10.1177/1057083713487214

Powell, S. R. (2014). Examining preservice music teacher concerns in peer- and fieldteaching settings. Journal of Research in Music Education, 61, 361-378. doi: $10.1177 / 0022429413508408$

Powell, S. R. (2016). The influence of video reflection on preservice music teachers' concerns in peer-and field-teaching settings. Journal of Research in Music Education, 63, 487-507. doi:10.1177/0022429415620619

Price, H. E., \& Winter, S. (1991). Effect of strict and expressive conducting on performances and opinions of eighth-grade band students. Journal of Band Research, 27, 30-43. 
Price, H. E., \& Yarbrough, C. (1993). Effect of scripted sequential patterns of instruction in music rehearsals on teaching evaluations by college nonmusic students. Bulletin of the Council for Research in Music Education, 119, 170-178. Retrieved from https://www.jstor.org/stable/40318627

Prichard, S. (2017). A mixed-methods investigation of preservice music teaching efficacy beliefs and commitment to music teaching. Journal of Research in Music Education, 65, 237-257. doi:10.1177/0022429417710387

Pyper, J. S. (2014). Pre-service mathematics teacher efficacy: Its nature and relationship to teacher concerns and orientation. Alberta Journal of Educational Research, 60, 81-97. Retrieved from https://journalhosting.ucalgary.ca/index.php/ajer/article/view/55768/42635

Quesada, M. (1992). The effects of providing teaching materials and an in-service workshop concerning Puerto Rican music on music teachers' self-efficacy and willingness to teach Puerto Rican music (Doctoral dissertation). Retrieved from ProQuest Dissertations and Theses database. (Order No. 9316061)

Ralph, E. G. (1993). Sensitive, sensible student teaching supervision: A contextual application in Saskatchewan. Alberta Journal of Educational Research, 39, 283296. Retrieved from ERIC database. (EJ474826)

Regier, B. J. (2018). A measurement of self-efficacy among Oklahoma secondary band directors in concert, marching, and jazz ensemble pedagogy. Update: Applications of Research in Music Education. Advanced online publication. doi:10.1177/8755123318808246 
Riggs, I. M., \& Enochs, L. G. (1990). Toward the development of an elementary teacher's science teaching efficacy belief instrument. Science Education, 74, 625637. doi:10.1002/sce.3730740605

Ritchie, L., \& Williamon, A. (2011). Primary school children's self-efficacy for music learning. Journal of Research in Music Education, 59, 146-161. doi:10.1177/0022429411405214

Roeser, R. W., Schonert-Reichl, K. A., Jha, A., Cullen, M., Wallace, L., Wilensky, R., ... \& Harrison, J. (2013). Mindfulness training and reductions in teacher stress and burnout: Results from two randomized, waitlist-control field trials. Journal of Educational Psychology, 105, 787-804. doi:10.1037/a0032093

Roland, D. (1994). How professional performers manage performance anxiety. Research Studies in Music Education, 2(1), 25-35. doi:10.1177/1321103X9400200105

Roland, D. (1997). The confident performer. Sydney, Australia: Currency.

Ross, J. A. (1992). Teacher efficacy and the effects of coaching on student achievement. Canadian Journal of Education, 17, 51-65. Retrieved from http://www.jstor.org/stable/1495395

Ross, J. A. (1994). The impact of an inservice to promote cooperative learning on the stability of teacher efficacy. Teaching and Teacher Education, 10, 381-394. doi:10.1016/0742-051X(94)90020-5

Ross, J. A., Hogaboam-Gray, A., \& Hannay, L. (2001). Effects of teacher efficacy on computer skills and computer cognitions of Canadian students in grades $\mathrm{K}-3$. The Elementary School Journal, 102, 141-156. Retrieved from http://www.jstor.org/stable/1002205 
Royston, N. S. (2013). The relationship between collegiate band members' preferences of teacher interpersonal behavior and perceived self-efficacy. Research and Issues in Music Education, 11(1), 1-17. Retrieved from

http://ir.stthomas.edu/rime/vol11/iss1?utm_source=ir.stthomas.edu $\% 2$ Frime $\% 2 F v$ ol11\% 2Fiss 1\%2F7\&utm_medium=PDF\&utm_campaign=PDFCoverPages

Sang, R. C. (1987). A study of the relationship between instrumental music teachers' modeling skills and pupil performance behaviors. Bulletin of the Council for Research in Music Education, 91, 155-159.

https://www.jstor.org/stable/40318077

Schmidt, M. (2012). Transition from student to teacher: Preservice teachers' beliefs and practices. Journal of Music Teacher Education, 23, 27-49.

doi: $10.1177 / 1057083712469111$

Schunk, D. H. (1982). Effects of effort attributional feedback on children's perceived self-efficacy and achievement. Journal of Educational Psychology, 74, 548-556. doi:10.1037/0022-0663.74.4.548

Schunk, D. H. (1984). Sequential attributional feedback and children's achievement behaviors. Journal of Educational Psychology, 76, 1159-1169. doi:10.1037/0022-0663.76.6.1159

Schunk, D. H. (1987). Peer models and children's behavioral change. Review of Educational Research, 57, 149-174. doi:10.3102/00346543057002149

Schunk, D. H., \& Cox, P. D. (1986). Strategy training and attributional feedback with learning disabled students. Journal of Educational Psychology, 78, 201-209. doi:10.1037/0022-0663.78.3.201 
Schunk, D. H., \& Zimmerman, B. J. (2007). Influencing children's self-efficacy and selfregulation of reading and writing through modeling. Reading \& Writing Quarterly, 23(1), 7-25. doi:10.1080/10573560600837578

Schwarzer, R., \& Hallum, S. (2008). Perceived teacher self-efficacy as a predictor of job stress and burnout: Mediation analyses. Applied psychology, 57, 152-171. doi:10.1111/j.1464-0597.2008.00359.x

Seligman, M. (1995). The optimistic child. Sydney, Australia: Random House.

Sidoti, V. J. (1990). The effects of expressive and nonexpressive conducting on the performance accuracy of selected expression markings by individual high school instrumentalists. Dissertation Abstracts International, 51, 3270A. Retrieved from https://etd.ohiolink.edu/!etd.send_file?accession=osu1487683401443805\&disposi tion=inline

Siebenaler, D. J. (1997). Analysis of teacher-student interactions in the piano lessons of adults and children. Journal of Research in Music Education, 45, 6-20. doi: $10.2307 / 3345462$

Silvey, B. A., \& Koerner, B. D. (2016). Effects of conductor expressivity on secondary school band members' performance and attitudes toward conducting. Journal of Research in Music Education, 64, 29-44. doi:10.1177/0022429415622451

Sims, W. L., \& Cassidy, J. W. (2018). Impostor phenomenon responses of early career music education faculty. Journal of Research in Music Education, 67, 45-61. doi: $10.1177 / 0022429418812464$

Smith, S. M. (2001). The four sources of influence on computer self-efficacy. Delta Pi Epsilon, 43, 27-39. Retrieved from: https://www.learntechlib.org/p/93437/ 
Stanley, J. M., \& Madsen, C. K. (1991). An observation procedure to differentiate teaching experience and expertise in music education. Journal of Research in Music Education, 39, 5-11. doi:10.2307/3344604

Stein, M. K., \& Wang, M. C. (1988). Teacher development and school improvement: The process of teacher change. Teaching and Teacher Education, 4, 171-187. doi:10.1016/0742-051X(88)90016-9

Teachout, D. (1997). Preservice and experienced teachers' opinions of skills and behaviors important to successful music teaching. Journal of Research in Music Education, 45, 41-50. doi:10.2307/3345464

Tschannen-Moran, M., \& Johnson, D. (2011). Exploring literacy teachers' self-efficacy beliefs: Potential sources at play. Teaching and Teacher Education, 27, 751-761. doi:10.1016/j.tate.2010.12.005

Tschannen-Moran, M., \& McMaster, P. (2009). Sources of self-efficacy: Four professional development formats and their relationship to self-efficacy and implementation of a new teaching strategy. The Elementary School Journal, 110, 228-245. doi:10.1086/605771

Tschannen-Moran, M., \& Woolfolk Hoy, A. (2001). Teacher efficacy: Capturing and elusive construct. Teaching and Teacher Education, 17, 783-805. doi:10.1016/S0742-051X(01)00036-1

Tschannen-Moran, M., \& Woolfolk Hoy, A. (2007). The differential antecedents of selfefficacy beliefs of novice and experienced teachers. Teaching and Teacher Education, 23, 944-956. doi:10.1016/j.tate.2006.05.003 
Tschannen-Moran, M., Woolfolk Hoy, A., \& Hoy, W. K. (1998). Teacher efficacy: Its meaning and measure. Review of Educational Research, 68, 202-248. doi: $10.3102 / 00346543068002202$

Usher, E. L., \& Pajares, F. (2006). Sources of academic and self-regulatory efficacy beliefs of entering middle school students. Contemporary Educational Psychology, 31, 125-141. doi:10.1016/j.cedpsych.2005.03.002

Usher, E. L., \& Pajares, F. (2008). Sources of self-efficacy in school: Critical review of the literature and future directions. Review of Educational Research, 78, 751-796. doi: $10.3102 / 0034654308321456$

VanWeelden, K., \& McGee, I. R. (2007). The influence of music style and conductor race on perceptions of ensemble and conductor performance. International Journal of Music Education, 25, 7-19. doi:10.1177/0255761407074886

Wagoner, C. L. (2011). Defining and measuring music teacher identity: A study of selfefficacy and commitment among music teachers (Doctoral dissertation). Retrieved from ProQuest Dissertations and Theses database. (Order No. 3457596)

Watson, K. (2010). The effects of aural versus notated instructional materials on achievement and self-efficacy in jazz improvisation. Journal of Research in Music Education, 58, 240-259. doi:10.1177/0022429410377115

Wehr-Flowers, E. (2006). Differences between males and females in confidence, anxiety, and attitude towards learning jazz improvisation. Journal of Research in Music Education, 54, 337-349. doi:10.1177/002242940605400406 
Weinstein, C. S. (1990). Prospective elementary teachers' beliefs about teaching: Implications for teacher education. Teaching and Teacher Education, 6, 279-290. doi:10.1016/0742-051X(90)90019-2

Wesner, R. B., Noyes Jr, R., \& Davis, T. L. (1990). The occurrence of performance anxiety among musicians. Journal of Affective Disorders, 18, 177-185. doi:10.1016/0165-0327(90)90034-6

Whitaker, J. A. (2011). High school band students' and directors' perceptions of verbal and nonverbal teaching behaviors. Journal of Research in Music Education, 39, 5-11. doi:10.1177/0022429411414910

Wilson, G. D. (2002). Psychology for performing artists. (2nd ed.). London, UK: Whurr. Wilson, G. D., \& Roland, D. (2002). Performance anxiety. In R. Parncutt \& G. E. McPherson (Eds.), The science and psychology of music performance: Creative strategies for teaching and learning, (pp. 47-61). New York, NY: Oxford University Press.

Woolfolk Hoy, A., \& Burke-Spero, R. (2005). Changes in teacher-efficacy beliefs during the early years of teaching: A comparison of four measures. Teaching and Teacher Education, 21, 343-356. doi:10.1016/j.tate.2005.01.007

Woolfolk Hoy, A., \& Davis, H. A. (2006). Teacher self-efficacy and its influence on the achievement of adolescents. In F. Pajares \& T. Urdan, (Eds.), Self-efficacy beliefs of adolescents (pp. 117-137). Greenwich, CT: Information Age.

Worthy, M. D. (2005). The effects of self-evaluation on the timing of teacher and student behaviors in lab rehearsals. Journal of Music Teacher Education, 15, 8-14. doi: $10.1177 / 10570837050150010103$ 
Yarbrough, C. (1975). Effect of magnitude of conductor behavior on students in selected mixed choruses. Journal of Research in Music Education, 23, 134-146. doi: $10.2307 / 3345286$

Yarbrough, C. E., \& Madsen, K. (1998). The evaluation of teaching in choral rehearsals. Journal of Research in Music Education, 46, 469-481. doi:10.2307/3345344

Yarbrough, C., \& Price, H. E. (1981). Prediction of performer attentiveness based on rehearsal activity and teacher behavior. Journal of Research in Music Education, 29, 209-217. doi:10.2307/3344994

Yin, R. K. (2009). Case study research and applications: Design and methods (4th ed.). Thousand Oaks, CA: Sage.

Yourn, B. R. (2000). Learning to teach: Perspectives from beginning music teachers. Music Education Research, 2, 181-192. doi:10.1080/14613800050165631

Zeldin, A. L., Britner, S. L., \& Pajares, F. (2008). A comparative study of the selfefficacy beliefs of successful men and women in mathematics, science, and technology careers. Journal of Research in Science Teaching, 45, 1036-1058. doi:10.1002/tea.20195

Zeldin, A. L., \& Pajares, F. (2000). Against the odds: Self-efficacy beliefs of women in mathematical, scientific, and technological careers. American Educational Research Journal, 37, 215-246. doi:10.3102/00028312037001215

Zelenak, M. S. (2015). Measuring the sources of self-efficacy among secondary school music students. Journal of Research in Music Education, 62, 389-404. doi:10.1177/0022429414555018 


\section{Appendix A}

Email Subject Line: Band Director Self-Efficacy Research Survey

Dear Concert Band Director,

My name is Bradley Regier, and I am currently working on my PhD in Music Education at the University of Missouri-Columbia. My dissertation, supervised by Dr. Brian Silvey, concerns high school concert band directors' self-efficacy for teaching strategies. As a result, I am requesting your participation in my study.

This study has been approved by the University of Missouri-Columbia Institutional Review Board. The survey will take approximately 5 minutes to complete. Participation is completely voluntary and would be greatly appreciated. Your identity will not be connected to your responses. The University of Missouri is an Equal Opportunity Institution.

The survey can be accessed by clicking the link below.

https://missouri.qualtrics.com/jfe/form/SV_9WwiLe4Lk1IUruB

If you have any questions, you may contact me, Mr. Bradley J. Regier, (xxxxxxx) at xxxxxx-Xxxx, or the University of Missouri Institutional Review Board (IRB) at 573-8823181.

I hope that you will choose to help with this short, but important survey that will help us understand more about the influences and outcomes of concert band directors' selfefficacy.

Sincerely,

Bradley J. Regier

bregier@mail.missouri.edu 


\section{Appendix B}

Your IRB Application to project entitled The Influences and Outcomes of Concert Band Directors' Self-Efficacy for Teaching Strategies was reviewed and approved by the MU Institutional Review Board according to the terms and conditions described below:

$\begin{array}{ll}\text { IRB Project Number } & 2012704 \\ \text { IRB Review Number } & 241567 \\ \text { Initial Application Approval Date } & \text { September 25, } 2018 \\ \text { IRB Expiration Date } & \text { September 25, 2019 } \\ \text { Level of Review } & \text { Exempt } \\ \text { Project Status } & \text { Active - Exempt } \\ \text { Exempt Categories } & 45 \text { CFR 46.101b(2) } \\ \text { Risk Level } & \text { Minimal Risk }\end{array}$

The principal investigator (PI) is responsible for all aspects and conduct of this study. The PI must comply with the following conditions of the approval:

1. No subjects may be involved in any study procedure prior to the IRB approval date or after the expiration date.

2. All changes must be IRB approved prior to implementation utilizing the Exempt Amendment Form.

3. The Annual Exempt Form must be submitted to the IRB for review and approval at least 30 days prior to the project expiration date to keep the study active or to close it.

4. Maintain all research records for a period of seven years from the project completion date.

If you are offering subject payments and would like more information about research participant payments, please click here to view the MU Business Policy and Procedure: http://bppm.missouri.edu/chapter2/2_250.html

If you have any questions, please contact the IRB at 573-882-3181 or irb@missouri.edu.

Thank you,

MU Institutional Review Board 


\author{
Appendix C \\ Examining Concert Band Directors' Self-Efficacy for Teaching Strategies \\ Conducted by: Bradley J. Regier \\ School of Music, The University of Missouri \\ Telephone: $x x x . x x x . x x x x$ \\ Email: $x x x x x x x$
}

You are being asked to participate in a research study. This form provides you with information about the study. Please read the information below and ask questions about anything you do not understand before deciding whether or not to take part. Your participation is entirely voluntary and you can refuse to participate without penalty or loss of benefits to which you are otherwise entitled. You can stop your participation at any time and your refusal will not impact current or future relationships with MU or participating sites. To do so simply close the survey in your web browser to stop participation.

The purpose of this study is to examine concert band directors' efficacy for teaching strategies.

If you agree to participate in this study, we will ask you to do the following things:

- Rate your level of agreement to items on a scale.

- Provide anonymous demographic information

Total estimated time to participate in the study is 5 minutes.

Risks and Benefits:

The risk associated with this study is no greater than everyday life. Possible benefits of this study include reflecting on your own conducting behaviors.

Compensation:

You will not be compensated for your participation in this study.

\title{
Confidentiality:
}

The evaluation forms used in this study will be stored securely and kept anonymously.

Authorized persons from The University of Missouri, members of the Institutional Review Board, and (study sponsors, if any) have the legal right to review your research records and will protect the anonymity of those records to the extent permitted by law. All publications will exclude any information that will make it possible to identify you as a subject. Throughout the study, the researchers will notify you of new information that may become available and that might affect your decision to remain in the study.

\section{Contacts and Questions:}

If you have any questions about the study, please notify the author. If you have questions later, want additional information, or wish to withdraw your participation, call the researcher conducting the study. The name, phone number, and e-mail address are at the top of this page. You may contact the Campus Institutional Review Board if you have questions about your rights, concerns, complaints or comments as a research participant. You can contact the Campus Institutional Review Board directly by telephone or email to voice or solicit any concerns, questions, input or complaints about the research study.

483 McReynolds Hall

Columbia, MO 65211

573-882-9585

To consent to this research and begin the study, press the "Next" button below. 


\section{Appendix D}

\section{Concert Band Directors' Self-Efficacy for Teaching Strategies Scale}

Please rate your level of confidence for each item below on a scale from 0 (Not Confident) to 10 (Highly Confident).

In a concert band setting, I can...

1. Use a variety of assessment strategies.

2. Provide an alternative explanation or example when students are confused.

3. Adjust my teaching to the proper difficulty level for individual students.

4. Implement alternative teaching strategies in the classroom. 


\title{
Appendix E
}

\author{
Sources of Self-Efficacy for Concert Band Teaching Scale
}

Please rate your level of agreement for each item below on a scale from 0 (Strongly

Disagree) to 10 (Strongly Agree).

\section{Enactive Mastery Experiences}

1. I have had positive experiences teaching concert band in the past.

2. I have had positive experiences teaching simple concert band music in the past.

3. I have had positive experiences teaching complicated concert band music in the past.

4. I have overcome concert band teaching challenges through hard work.

5. I have always been a good at teaching concert band.

6. I am excellent at teaching in a concert band setting.

\section{Vicarious Experiences}

7. I have improved my concert band teaching by watching other successful concert band teachers.

8. I have used other concert band teachers as models to improve my own teaching.

9. I have watched other conductors teach a piece of music and then decided whether I could, or could not, teach the same piece of music.

10. I have compared my concert band teaching ability with those of other teachers who are similar in teaching ability to me.

11. Seeing colleagues do better than me at teaching concert band pushes me to be better.

12. I imagine myself teaching challenging concert band music successfully.

\section{Verbal Persuasion}

13. People have told me I have a talent for teaching concert band.

14. I have received positive feedback on my concert band teaching evaluations.

15. Individuals I respect have told me I am good at teaching concert band.

16. My friends think I am a good concert band teacher.

17. People compliment me on my concert band teaching ability.

18. Colleagues have told me I am a good concert band teacher.

\section{Physiological State}

19. I have learned to control my nervousness while teaching concert band music.

20. Teaching concert band makes me feel good.

21. I do not worry about making small mistakes while teaching concert band.

22. I enjoy teaching concert band.

23. I have positive memories of most, or all, of my past concert band teaching experiences.

24. I get excited when I think about teaching concert band. 


\section{Appendix F}

\section{Effective Teaching Skills}

Rate your level of effectiveness for the teacher skills listed below from 0 (Not Effective) to 10 (Highly Effective)

1. Maintain classroom management and procedures

2. Employ a positive approach to rehearsals

3. Motivate students

4. Maintain student behavior (strong but fair discipline)

5. Maintain an effective rehearsal pace

6. Involve students in the learning process

7. Maximize students' time on task

8. Present a lesson with clarity

9. Work with students of different ages and abilities

10. Frequently make eye contact with students 


\section{Appendix G}

Survey Demographic Items

What gender do you identify with?

Female

O Male

Non-binary/Third gender

Prefer not to respond

What is your highest degree completed?
O Bachelors
Masters
O Doctorate

How many years have you taught high school concert band? Please provide a whole number and include the current school year in your total.

Which grade levels do you currently teach? (Mark all that apply)

$\begin{array}{ll}\square & \mathrm{K}-5 \\ \square & 6-8 \\ \square & 9-12\end{array}$

What population area does your high school serve?

O Rural / Small Town

O Suburban / City School

Urban / Large City School

Approximately how many students attend the high school in which you teach? 
What type of school do you currently teach in?

O Public

Charter

Private / Parochial

What is the status of your position?

O Full Time

Part Time (provide \% of full time equivalent)

Which NAfME region do you currently teach in? https://nafme.org/about/federated-statemusic-education-associations/

O Eastern

North Central

O Northwest

Southern

Southwestern

Western 


\section{Appendix H}

방

Institutional Review Board

University of Missouri-Columbia

FWA Number: 0002876

IRB Registration Numbers: 00000731, 00009014
482 McReynolds Hall

Columbia, MO 65211

573-882-3181

irb@missouri.edu

October 03, 2018

Principal Investigator: Bradley Regier

Department: School of Music

Your IRB Application to project entitled Examining the Concerns and Efficacious Experiences of Preservice Teachers was reviewed and approved by the MU Institutional Review Board according to the terms and conditions described below:

$\begin{array}{ll}\text { IRB Project Number } & 2012720 \\ \text { IRB Review Number } & 241601 \\ \text { Initial Application Approval Date } & \text { October 03, 2018 } \\ \text { IRB Expiration Date } & \text { October 03, 2019 } \\ \text { Level of Review } & \text { Exempt } \\ \text { Project Status } & \text { Active - Exempt } \\ \text { Exempt Categories } & 45 \text { CFR 46.101b(2) } \\ \text { Risk Level } & \text { Minimal Risk }\end{array}$

The principal investigator (PI) is responsible for all aspects and conduct of this study. The PI must comply with the following conditions of the approval:

1. No subjects may be involved in any study procedure prior to the IRB approval date or after the expiration date.

2. All changes must be IRB approved prior to implementation utilizing the Exempt Amendment Form.

3. The Annual Exempt Form must be submitted to the IRB for review and approval at least 30 days prior to the project expiration date to keep the study active or to close it.

4. Maintain all research records for a period of seven years from the project completion date.

If you are offering subject payments and would like more information about research participant payments, please click here to view the MU Business Policy and Procedure:

http://bppm.missouri.edu/chapter2/2_250.html

If you have any questions, please contact the IRB at 573-882-3181 or irb@missouri.edu.

Thank you,

MU Institutional Review Board 


\title{
Appendix I
}

\section{CONSENT Form to PARTICIPATE IN A RESEARCH STUdY}

\author{
Researcher's Name(s): Bradley J. Regier \\ Project Number: 2012720 \\ Project Title: Examining the Concerns and Influences of Preservice Teacher Self-Efficacy \\ INTRODUCTION
}

This consent may contain words that you do not understand. Please ask the investigator or the study staff to explain any words or information that you do not clearly understand.

You are being asked to participate in a research study. This research is being conducted to investigate the influences and outcomes of preservice conductor teaching efficacy and their concerns. When you are invited to participate in research, you have the right to be informed about the study procedures so that you can decide whether you want to consent to participation. This form may contain words that you do not know. Please ask the researcher to explain any words or information that you do not understand.

You have the right to know what you will be asked to do so that you can decide whether or not to be in the study. Your participation is voluntary. You do not have to be in the study if you do not want to. You may refuse to be in the study and nothing will happen. If you do not want to continue to be in the study, you may stop at any time without penalty or loss of benefits to which you are otherwise entitled.

There is no consequence to terminating your participation in this study. To end your participation, simply email the researcher that you wish to stop participating.

This research is not funded by any organization.

\section{WHY IS THIS STUDY BEING DONE?}

The purpose of this research is to investigate the influences of preservice conductor self-efficacy for teaching, as well as their teaching concerns.

\section{HOW MANY PEOPLE WILL BE IN THE STUDY?}

About _ $\quad 4 \_$people will take part in this study at this institution.

\section{WHAT AM I BEING ASKED TO DO?}

You will be asked to provide written answers to short essay items at the beginning of the study. During the six weeks before student teaching and six weeks during student teaching, you will answer two questions for a weekly e-journal.

\section{HOW LONG WILL I BE IN THE STUDY?}


This study will take 12 weeks to complete. You can stop participating at any time without penalty.

\section{WHAT ARE THE BENEFITS OF BEING IN THE STUDY?}

Your participation will benefit your own ability to reflect on your teaching influences and concerns.

\section{WHAT ARE THE RISKS OF BEING IN THE STUDY?}

There are no foreseeable risks to participating in this study.

\section{WHAT ARE THE COSTS OF BEING IN THE STUDY?}

There is no cost to you.

\section{WHAT OTHER OPTIONS ARE THERE?}

You also have the option of not participating in this study, and will not be penalized for your decision.

\section{CONFIDENTIALITY}

The information you provide will be confidential and only the researcher and academic advisor will have access to the information. Pseudonyms will be given for all students used in a case study analysis.

Information produced by this study will be stored in the investigator's file and identified by a code number only. The code key connecting your name to specific information about you will be kept in a separate, secure location. Information contained in your records may not be given to anyone unaffiliated with the study in a form that could identify you without your written consent, except as required by law.

\section{WILL I BE COMPENSATED FOR PARTICIPATING IN THE STUDY?}

You will receive no payment for taking part in this study.

\section{WHAT ARE MY RIGHTS AS A PARTICIPANT?}

Participation in this study is voluntary. You do not have to participate in this study.

You will also be informed of any new information discovered during the course of this study that might influence your health, welfare, or willingness to be in this study.

\section{WHO DO I CONTACT IF I HAVE QUESTIONS, CONCERNS, OR COMPLAINTS?}

Please contact Brad Regier ( Additionally, you may ask questions, voice concerns or complaints to the research team. 


\section{WHOM DO I CALL IF I HAVE QUESTIONS OR PROBLEMS?}

If you have any questions regarding your rights as a participant in this research and/or concerns about the study, or if you feel under any pressure to enroll or to continue to participate in this study, you may contact the University of Missouri Campus Institutional Review Board (which is a group of people who review the research studies to protect participants' rights) at (573) 8829585 or umcresearchcirb@missouri.edu.

You may ask more questions about the study at any time. For questions about the study or a research-related injury, contact Brad Regier at Xxx.Xxx.xxxx

A copy of this Informed Consent form will be given to you before you participate in the research.

\section{SIGNATURES}

I have read this consent form and my questions have been answered. My signature below means that I do want to be in the study. I know that I can remove myself from the study at any time without any problems.

\section{Subject}

Legal Guardian/Advocate/Witness (if required)*

Additional Signature (if required) (identify relationship to subject)*

\section{Date}

\section{Date}

\section{Date}




\section{Appendix J}

\section{Interview Questions}

- How would you compare your professional teaching experiences to your field experiences? Do you feel that they both prepared you well to teach?

- What experiences during your student teaching have impacted your teaching confidence?

- How has your teaching confidence changed from your field experiences to student teaching?

- What emotions did you have for teaching before your student teaching began?

- How have your emotions changed during student teaching? 


\section{VITA}

Beginning in the fall of 2019, Bradley J. Regier will be Assistant Professor of Music Education at Illinois Wesleyan University. At IWU, he will teach courses in music education, supervise student teachers, conduct the Symphonic Winds, and provide oversight to the music education program. Previously he taught instrumental and general music courses in Kansas and Cairo, Egypt, and continues to clinic bands and percussion ensembles throughout the Midwest.

Mr. Regier's research has been presented at state, national, and international conferences including the Missouri Music Education Association annual conference (2019), the International Society for Music Education conference in Baku, Azerbaijan (2018), and the Music Research and Teacher Education National Conference in Atlanta, Georgia (2018). His research interests include music teacher self-efficacy, instrumental teaching strategies, and preservice teacher preparation. He is published in the International Journal of Music Education, Update: Applications of Research in Music Education, Missouri Journal of Research in Music Education, and the Missouri School Music Magazine.

Mr. Regier will receive his doctorate in Music Education from the University of Missouri-Columbia in the spring of 2019. He received his master's degree in music education with a wind conducting emphasis at the University of Oklahoma and his bachelor's degree in music education from Kansas State University. 